RODRIGO SARMENTO BARATA

O REGIME CONSTITUCIONAL DOS SERVIÇOS PÚBLICOS:

O QUE O STF TEM A NOS DIZER?

\author{
Dissertação de Mestrado \\ Orientador: Professor Titular Dr. Elival da Silva Ramos
}

UNIVERSIDADE DE SÃO PAULO

FACULDADE DE DIREITO

São Paulo-SP

2017 



\section{O Regime Constitucional dos Serviços Públicos: \\ O que o STF tem a nos dizer?}

Dissertação de Mestrado apresentada à Banca Examinadora do Programa de Pós-Graduação em Direito, da Faculdade de Direito da Universidade de São Paulo, como exigência parcial para obtenção do título de Mestre em Direito, na área de concentração de Direito do Estado, sob a orientação do Prof. Professor Titular Dr. Elival da Silva Ramos.

UNIVERSIDADE DE SÃO PAULO

FACULDADE DE DIREITO

São Paulo-SP 
Catalogação da Publicação

Serviço de Biblioteca e Documentação

Faculdade de Direito da Universidade de São Paulo

Sarmento Barata, Rodrigo

O Regime Constitucional dos Serviços Públicos: O que o STF tem a nos dizer? / Rodrigo Sarmento Barata ; orientador Elival da Silva Ramos -- São Paulo, 2017 .

139

Dissertação (Mestrado - Programa de Pós-Graduação em Direito do Estado) - Faculdade de Direito, Universidade de São Paulo, 2017.

1. Serviços Públicos. 2. Jurisprudência constitucional. 3. Supremo Tribunal Federal. I. da Silva Ramos, Elival, orient. II. Título. 


\section{AGRADECIMENTOS}

Jamais imaginei que tanto teria a agradecer ao final deste trabalho. A dedicação acadêmica - isso ficou claro nos últimos três anos - exige muita dedicação e muitos amigos. Sem eles, nada sairia do lugar.

Amigos para discutir e trocar ideias, amigos para dar conselhos, amigos para compreender a situação do pesquisador e todas as limitações, exigências e intempéries enfrentadas nos últimos anos. Muito aprendi e cresci nesse período e devo isso à Faculdade de Direito da Universidade de São Paulo, ao meu professor orientador, aos professores com quem convivi nesse período e colegas de pósgraduação. Além desses, os amigos de toda vida, a família e a equipe de amigos do Madrona Advogados, com quem tenho prazer de conviver todos os dias, merecem mais que mero agradecimento registrado neste pedaço de papel.

Ainda assim, tenho que pedir desculpas a todos, especialmente ao meu pai, minha mãe, Marcela e Ana Carolina, por mais importantes que sejam e, de fato, foram essenciais nessa jornada, para agradecer e dedicar todo o trabalho a uma única pessoa: minha avó Maria Helena.

Sem dúvidas, ela merece muito mais que essa simples menção. Talvez, o assunto aqui tratado sequer a interessasse, mas eu daria tudo para poder tê-lo discutido com ela. 
BARATA, Rodrigo Sarmento, O Regime Constitucional dos Serviços Públicos:

O que o STF tem a nos dizer?, 2017, 139 páginas, Dissertação de Mestrado Faculdade de Direito, Universidade de São Paulo, São Paulo, 2017.

\section{RESUMO}

Este trabalho buscou desenvolver uma metodologia de pesquisa para seleção, coleta e análise de todos os julgados proferidos pelo Supremo Tribunal Federal, tratando sobre serviços públicos, no período entre a promulgação da Constituição Federal e a data de corte estabelecida pela pesquisa (outubro/2013). Com isso, se propôs apresentar um panorama completo da compreensão da disciplina constitucional dos serviços públicos aos olhos do Supremo Tribunal Federal, permitindo ao pesquisador não apenas retratar o tema de pesquisa, mas também cruzar dados e informações com o objetivo de identificar outras características da atuação da Corte Constitucional brasileira. Para o desenvolvimento do trabalho foram criados procedimentos de análise e catalogação de dados, sendo que cada um dos 1.020 (mil e vinte) acórdãos originalmente identificados na pesquisa foram analisados e produzida uma ficha com informações colhidas de cada um. A partir da compilação e análise dos dados colhidos em cada acórdão, foi possível desenvolver a pesquisa e perceber como o STF se porta perante a temática dos serviços públicos, uma vez que essa é carregada de valores e não está tratada de modo exaustivo na Constituição Federal. Ao final, foi possível perceber que o STF atua com cautela no campo dos serviços públicos, valendo-se de mecanismos como o controle de pauta para, em muitas vezes, retardar seu julgamento até que a sociedade desenvolva suas próprias soluções à divergência jurídica apresentada à Corte.

Palavras-chave: Serviços Públicos - Jurisprudência Constitucional - Supremo Tribunal Federal. 
BARATA, Rodrigo Sarmento, The Constitutional Regime of Public Utilities: What does the STF have to tell us?, 2017, 139 pages, Masters Dissertation - Faculty of Law, University of São Paulo, São Paulo, 2017.

\begin{abstract}
This work aimed to develop a research methodology for the selection, collection and analysis of all the trials issued by Supremo Tribunal Federal (Brazilian Supreme Court), regarding public utilities, between the enactment of Brazilian Federal Constitution and the cut-off date established in this research (October/2013). Thus, it was proposed to present a complete outlook of the comprehension of the constitutional regime applied to public utilities, under Supreme Court's view, enabling the researcher not only to show the subject of the research, but also to cross data and information, in order to identify other features of Brazilian Constitutional Court action. For the development of this work, data analysis and cataloging procedures were created, and each of the 1,020 (thousand identified in the research was analyzed and a card was produced with information collected from each one. Based on the compilation and analysis of the data collected in each decision, it was possible to develop the research and to understand how STF addresses the issue of public utilities, since it is loaded with values and not exhaustively dealt with the Federal Constitution. At the end, it was possible to perceive that STF acts with caution in the field of public services, using mechanisms such as the control of agenda to often delay its judgments until society develops its own solutions to the legal divergence presented to the Court.
\end{abstract}

Keywords: Public Services / Public Utilities - Constitutional Jurisprudence Supremo Tribunal Federal / Supreme Court. 


\section{ÍNDICE}

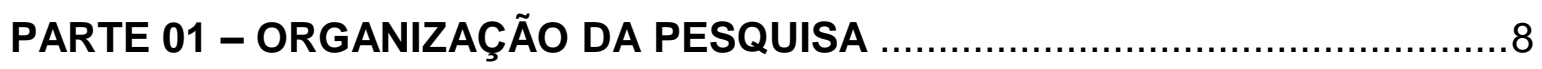

I. APRESENTAÇÃO

II. O PROBLEMA DOS SERVIÇOS PÚBLICOS NA SOCIEDADE..................27

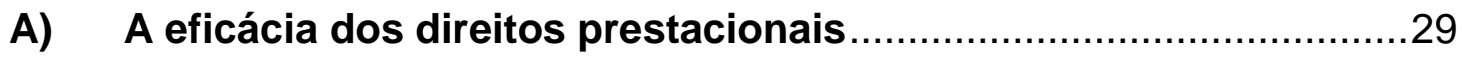

B) A intervenção do Estado na atividade econômica ...........................35

III. O PROBLEMA DOS SERVIÇOS PÚBLICOS NO DIREITO …....................38

A) A Constituição Federal de 1988 e os serviços público ...................40

B) Entre a noção e o regime jurídico .............................................4 48

IV. REVISÃO BIBLIOGRÁFICA DOS SERVIÇOS PÚBLICOS NO UNIVERSO

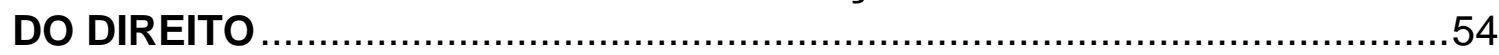

V. CONSIDERAÇÕES SOBRE A PESQUISA JURISPRUDENCIAL NA

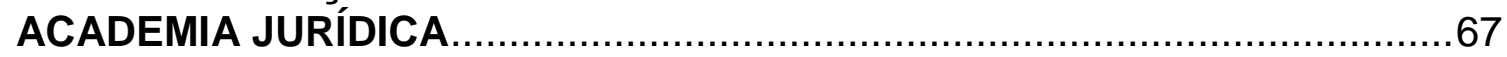

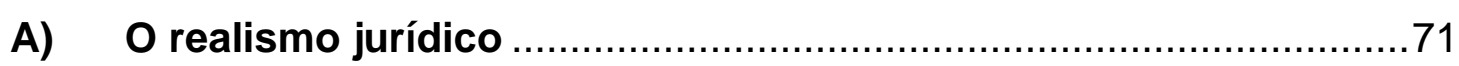

B) Perspectivas comportamental, institucional e econômica das decisões da Corte Constitucional ....................................................

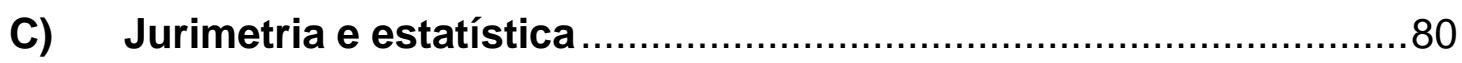

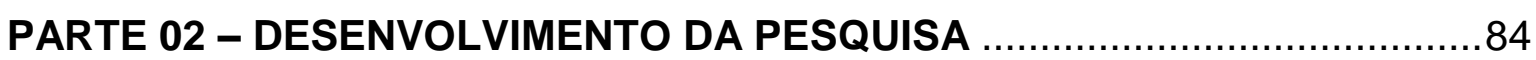

VI. DELIMITAÇÃO DA PESQUISA E PLANO DE TRABALHO …...................84

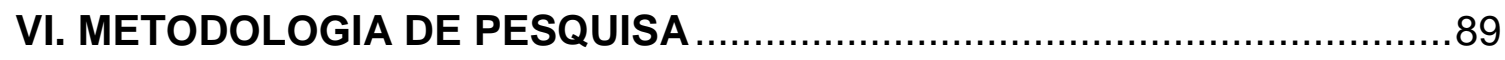

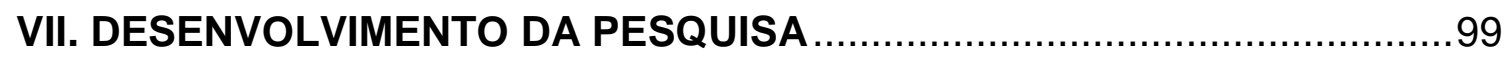

IX. ORGANIZAÇÃO DOS RESULTADOS OBTIDOS .................................103

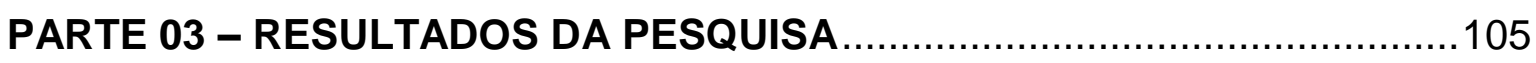

$X$. ANÁLISE DO COMPORTAMENTO DO STF NO TRATAMENTO DOS

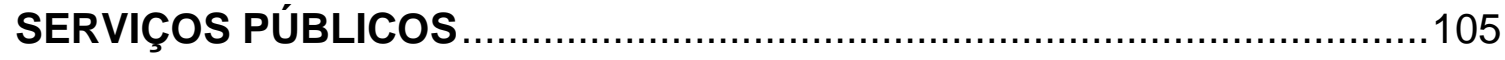

XI. ANÁLISE DO REGIME CONSTITUCIONAL DOS SERVIÇOS PÚBLICOS A PARTIR DOS RESULTADOS DA PESQUISA .........................................123

XII. APROXIMAÇÕES E ENFRENTAMENTOS DA DOUTRINA DOS SERVIÇOS PÚBLICOS EM FACE DA JURISPRUDÊNCIA DO STF A ESSE RESPEITO

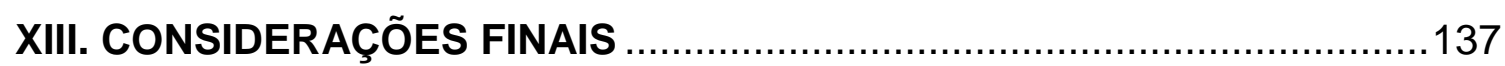

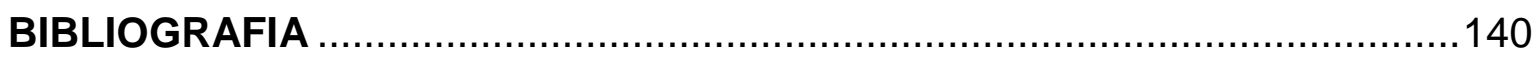

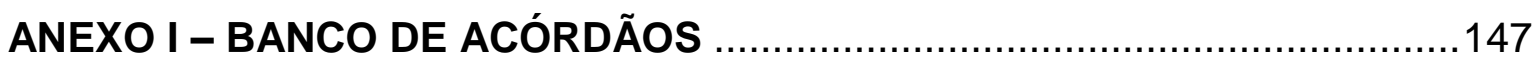

ANEXO II - FORMULÁRIO DE ANÁLISE DE CASOS ...................................193

ANEXO III - PLANILHA DE CONTROLE …….........................................194 


\section{PARTE 01 - ORGANIZAÇÃO DA PESQUISA}

\section{APRESENTAÇÃO}

Cortes Constitucionais são instituições fascinantes. O interesse que despertam nos mais variados campos do conhecimento é justificado, afinal, foram moldadas ao longo de sua história - intencionalmente ou não - para assumir papel de protagonistas na sociedade dos dias atuais (Vieira, 2008) ${ }^{1}$. Além de juristas, especialmente os dedicados ao estudo do Direito Constitucional, as Cortes constitucionais atraem interesses de outros campos, como cientistas políticos, entusiasmados pela feição política da atuação da Corte, e os mais diversos atores da sociedade - inclusive a mídia e o público em geral ${ }^{2}$ - interessados, muitas vezes, em casos ou causas específicos, isto é, no impacto que determinada decisão da Corte (com efeitos muitas vezes erga omnes, seja por ordem normativa ou por

\footnotetext{
${ }^{1}$ Ainda que se devam considerar as diferenças de arcabouço jurídico-institucional em cada jurisdição e o perfil das respectivas constituições - para melhor compreensão vide (Moraes, Jurisdição Constitucional e Tribunais Constitucionais; Garantia suprema da constituição, 2000) e (Cappelletti, 1999) - pode-se notar um movimento quase que global (ao menos no mundo ocidental) de evolução do papel da Corte Constitucional na organização da sociedade contemporânea. A literatura mais farta sobre o tema é, por certo, a estadunidense, em que a problematização da Suprema Corte é discutida há mais tempo (um dos principais temas lá discutidos é a politização da Suprema Corte e seu papel na democracia, um debate relevante entre, por exemplo, Dworkin (1989-1990) e Waldron (2006). Considerando o perfil da Constituição dos EUA (enxuta) e a tradição do common law (vinculação a precedentes, stare decisis), a atuação da Suprema Corte teve papel fundamental no desenvolvimento da sociedade norte-americana, desde a criação do judicial review, com Marshall, decisões fundamentais sobre segregação racial e tantos outros temas decididos no âmbito da jurisdição constitucional. A análise histórica da Suprema Corte por Chef Justices e suas respectivas atuações dá uma boa perspectiva do papel da Corte constitucional nesse diálogo institucional da divisão de poderes na sociedade (Schwartz, 1993). No Brasil, o STF teve e tem papel relevante, mas talvez seu expoente tenha se consolidado após a Constituição Federal de 1988 e ainda assim, somente após uma renovação quase que completa dos membros da Corte (importados, originalmente, do regime constitucional anterior) é que se tenha assumido protagonismo mais evidente - em uma análise do período entre 2002 e 2010, Gilmar Ferreira Mendes exemplifica a efervescência constitucional dos anos mais recentes do STF (Mendes G. F., Estado de DIreitro e Jurisdição Constitucional - 2002-2010, 2011).

${ }^{2}$ No Brasil, há bons exemplos do Supremo Tribunal Federal sob os holofotes da mídia. Casos de grande repercussão nacional, como o Mensalão e os processos de impeachment dos ex-presidentes Fernando Collor de Mello e Dilma Rousseff, foram intensamente acompanhados pelo público.
} 
decorrência interpretativa ${ }^{3}$ ) surtirá em suas vidas, na sociedade ou apenas contrariando suas opiniões e convicções pessoais ${ }^{4}$.

A Corte constitucional, entenda-se ou não adequado, tem exercido, na prática, papel ativo na construção dos direitos da sociedade de um modo geral (cidadão, grupos específicos, minorias, Estado). É por isso que a discussão sobre o papel da Corte constitucional permanece tão atual. Discutir a atuação da Corte no exercício do controle de constitucionalidade, seja de modo abstrato ou na abordagem de casos concretos, não deixa de ser uma discussão da democracia contemporânea (Mendes C. H., Constitutional Courts and Deliberative Democracy, 2013). Ao contrário da divisão de atribuições entre os Poderes Executivo e Legislativo, a interface desses dois últimos com o Judiciário não é tão clara. Sem a pretensão de um juízo de valor, a ingerência da jurisdição constitucional sobre atuação legislativa, não mais como mero agente de veto (Hoennige, Gschwend, Engst, \& Wittig, 2016), mas efetivo legislador positivo (Ramos, 2010), é clara, seja de modo positivado, como a Súmula Vinculante (art. 103-A, da Constituição Federal) ou em suas decisões (vide ADI 3510 ou MI 712).

Situação semelhante é vivenciada pelo Poder Executivo, por vezes ordenado a atuar ativamente, ou seja, recebendo um mandado de cumprimento de determinada política pública, nem sempre existente no planejamento da Administração, isto é, não compatível com o orçamento disponível, ou na própria lei. Caso clássico é o do fornecimento de medicamentos pelo Sistema Único de Saúde - SUS, uma promessa universalizada (uma garantia prescrita pela Constituição Federal especialmente nos artigos 6ำ e 196) que é constantemente efetivada pelo STF (e restante do Judiciário), ainda que fora da cobertura do SUS (Nunes \& Scaff, 2011). A expansividade da Constituição Federal na garantia de direitos que dependem de prestações positivas do Estado (políticas públicas), que

\footnotetext{
${ }^{3}$ (Mendes G. F., O papel do Senado Federal no controle de constitucionalidade: um caso clássico de mutação constitucional, 2004)

${ }^{4}$ Pode-se notar que em muitas circunstâncias o STF surge na mídia não apenas por decisões que afetem diretamente as vidas das pessoas, mas pela repercussão que determinado caso toma na sociedade. Muitas situações criminais que impactaram a sociedade, tiveram algum desfecho na Corte constitucional, dadas suas competências expansivas trazidas na Constituição (art. 102).
} 
é justificada pelo contexto em que a Constituição Federal de 1988 foi promulgada ${ }^{5}$, somada ao papel mais ativo da Corte constitucional na busca de conferir efetividade à Constituição, direcionaram as instituições para sua configuração atual (Mendes C. H., 2008, pp. 137-196). Elival da Silva Ramos (2010, p. 271) demonstra o resultado desse arranjo com clareza:

\begin{abstract}
Ao Poder Judiciário deveria caber, nesse modelo, o controle jurídico da atividade intervencionista dos demais Poderes. No entanto, sobre ele também recaem as expectativas e pressões da sociedade no sentido da mais célere possível consecução dos fins traçados na Constituição, incluindo a imediata fruição de direitos sociais ou a extensão de benefícios, de universalização progressiva, concedidos a determinadas categorias ou regiões com exclusão de outras. É nesse sentido que se pode dizer que o próprio modelo de Estado-providência constitui força impulsionadora do ativismo judicial, levando juízes e tribunais a relevar, em algumas situações, a existência de limites impostos pelo próprio ordenamento cuja atuação Ihes incumbe, na ilusão de poderem 'queimar' etapas, concretizando, no presente, o programa que a Constituição delineou prospectivamente.
\end{abstract}

Não se pretende adentrar à discussão do ativismo judicial, sua existência, legitimidade, causas ou consequências. Assume-se, porém, que o STF por vezes emite decisões que não se restringem à mera declaração de constitucionalidade ou não da norma em questão ou do atendimento ou não de determinada situação à realidade constitucional vigente ${ }^{6}$. Algumas decisões da Corte extrapolam os limites processuais originalmente definidos no ordenamento positivado (cada ação com seu regime próprio), sendo que estas atuações ampliativas tendem a conflitar com um dos demais Poderes da República.

Para exemplificar o cenário ora desenhado, é interessante buscar duas situações concretas, uma para cada conflito institucional acima tratado. A primeira é a ADPF $132^{7}$, julgada pelo STF em 2011. Nesse caso, a Corte reconheceu a

\footnotetext{
${ }^{5}$ Esse argumento decorre de dois fatores, um local e outro global. Por um lado, o Brasil acabava de encerrar o regime autoritário, após muita luta social - uma constituição cidadã era necessária. Por outro, o cenário internacional e de desenvolvimento do constitucionalismo contemporâneo indicava o mesmo rumo - veja-se a Constituição portuguesa, de 1976.

${ }^{6}$ Sobre este tema, interessante debate foi travado entre Luís Roberto Barroso (2015) e Ivar A Hartmann e Daniel Chada (2015).

${ }^{7}$ Em conjunto com a ADI 4277.
} 
legitimidade jurídica da união entre pessoas do mesmo sexo (união homoafetiva), legitimando-a como entidade familiar para todos os fins de Direito, ao equipará-la à união estável heteroafetiva ${ }^{8}$.

${ }^{8}$ A longa ementa resume de forma satisfatória o julgamento: "Ementa: 1. ARGUIÇÃO DE DESCUMPRIMENTO DE PRECEITO FUNDAMENTAL (ADPF). PERDA PARCIAL DE OBJETO. RECEBIMENTO, NA PARTE REMANESCENTE, COMO AÇÃO DIRETA DE INCONSTITUCIONALIDADE. UNIÃO HOMOAFETIVA E SEU RECONHECIMENTO COMO INSTITUTO JURÍDICO. CONVERGÊNCIA DE OBJETOS ENTRE AÇÕES DE NATUREZA ABSTRATA. JULGAMENTO CONJUNTO. Encampação dos fundamentos da ADPF n 132-RJ pela ADI no 4.277-DF, com a finalidade de conferir "interpretação conforme à Constituição" ao art. 1.723 do Código Civil. Atendimento das condições da ação. 2. PROIBIÇÃO DE DISCRIMINAÇÃO DAS PESSOAS EM RAZÃO DO SEXO, SEJA NO PLANO DA DICOTOMIA HOMEM/MULHER (GÊNERO), SEJA NO PLANO DA ORIENTAÇÃO SEXUAL DE CADA QUAL DELES. A PROIBIÇÃO DO PRECONCEITO COMO CAPÍTULO DO CONSTITUCIONALISMO FRATERNAL. HOMENAGEM AO PLURALISMO COMO VALOR SÓCIO-POLÍTICO-CULTURAL. LIBERDADE PARA DISPOR DA PRÓPRIA SEXUALIDADE, INSERIDA NA CATEGORIA DOS DIREITOS FUNDAMENTAIS DO INDIVÍDUO, EXPRESSÃO QUE É DA AUTONOMIA DE VONTADE. DIREITO À INTIMIDADE E À VIDA PRIVADA. CLÁUSULA PÉTREA. O sexo das pessoas, salvo disposição constitucional expressa ou implícita em sentido contrário, não se presta como fator de desigualação jurídica. Proibição de preconceito, à luz do inciso IV do art. 3ํㅜ da Constituição Federal, por colidir frontalmente com o objetivo constitucional de "promover o bem de todos". Silêncio normativo da Carta Magna a respeito do concreto uso do sexo dos indivíduos como saque da kelseniana "norma geral negativa", segundo a qual "o que não estiver juridicamente proibido, ou obrigado, está juridicamente permitido". Reconhecimento do direito à preferência sexual como direta emanação do princípio da "dignidade da pessoa humana": direito a auto-estima no mais elevado ponto da consciência do indivíduo. Direito à busca da felicidade. Salto normativo da proibição do preconceito para a proclamação do direito à liberdade sexual. O concreto uso da sexualidade faz parte da autonomia da vontade das pessoas naturais. Empírico uso da sexualidade nos planos da intimidade e da privacidade constitucionalmente tuteladas. Autonomia da vontade. Cláusula pétrea. 3. TRATAMENTO CONSTITUCIONAL DA INSTITUIÇÃO DA FAMÍLIA. RECONHECIMENTO DE QUE A CONSTITUIÇÃO FEDERAL NÃO EMPRESTA AO SUBSTANTIVO "FAMÍLIA" NENHUM SIGNIFICADO ORTODOXO OU DA PRÓPRIA TÉCNICA JURÍDICA. A FAMÍLIA COMO CATEGORIA SÓCIO-CULTURAL E PRINCÍPIO ESPIRITUAL. DIREITO SUBJETIVO DE CONSTITUIR FAMÍLIA. INTERPRETAÇÃO NÃOREDUCIONISTA. O caput do art. 226 confere à família, base da sociedade, especial proteção do Estado. Ênfase constitucional à instituição da família. Família em seu coloquial ou proverbial significado de núcleo doméstico, pouco importando se formal ou informalmente constituída, ou se integrada por casais heteroafetivos ou por pares homoafetivos. A Constituição de 1988, ao utilizar-se da expressão "família", não limita sua formação a casais heteroafetivos nem a formalidade cartorária, celebração civil ou liturgia religiosa. Família como instituição privada que, voluntariamente constituída entre pessoas adultas, mantém com o Estado e a sociedade civil uma necessária relação tricotômica. Núcleo familiar que é o principal lócus institucional de concreção dos direitos fundamentais que a própria Constituição designa por "intimidade e vida privada" (inciso X do art. $5^{\circ}$ ). Isonomia entre casais heteroafetivos e pares homoafetivos que somente ganha plenitude de sentido se desembocar no igual direito subjetivo à formação de uma autonomizada família. Família como figura central ou continente, de que tudo o mais é conteúdo. Imperiosidade da interpretação não-reducionista do conceito de família como instituição que também se forma por vias distintas do casamento civil. Avanço da Constituição Federal 
Penso que a decisão do STF foi justa ou, melhor, promoveu justiça, tomando a decisão mais acertada para o bem comum (Sandel, 2011). Essa opinião,

de 1988 no plano dos costumes. Caminhada na direção do pluralismo como categoria sócio-político-cultural. Competência do Supremo Tribunal Federal para manter, interpretativamente, o Texto Magno na posse do seu fundamental atributo da coerência, o que passa pela eliminação de preconceito quanto à orientação sexual das pessoas. 4 . UNIÂO ESTÁVEL. NORMAÇÃO CONSTITUCIONAL REFERIDA A HOMEM E MULHER, MAS APENAS PARA ESPECIAL PROTEÇÃO DESTA ÚLTIMA. FOCADO PROPÓSITO CONSTITUCIONAL DE ESTABELECER RELAÇÕES JURÍDICAS HORIZONTAIS OU SEM HIERARQUIA ENTRE AS DUAS TIPOLOGIAS DO GÊNERO HUMANO. IDENTIDADE CONSTITUCIONAL DOS CONCEITOS DE "ENTIDADE FAMILIAR" E "FAMÍLIA". A referência constitucional à dualidade básica homem/mulher, no $§ 3^{\circ}$ do seu art. 226, deve-se ao centrado intuito de não se perder a menor oportunidade para favorecer relações jurídicas horizontais ou sem hierarquia no âmbito das sociedades domésticas. Reforço normativo a um mais eficiente combate à renitência patriarcal dos costumes brasileiros. Impossibilidade de uso da letra da Constituição para ressuscitar o art. 175 da Carta de 1967/1969. Não há como fazer rolar a cabeça do art. 226 no patíbulo do seu parágrafo terceiro. Dispositivo que, ao utilizar da terminologia "entidade familiar", não pretendeu diferenciá-la da "família". Inexistência de hierarquia ou diferença de qualidade jurídica entre as duas formas de constituição de um novo e autonomizado núcleo doméstico. Emprego do fraseado "entidade familiar" como sinônimo perfeito de família. A Constituição não interdita a formação de família por pessoas do mesmo sexo. Consagração do juízo de que não se proíbe nada a ninguém senão em face de um direito ou de proteção de um legítimo interesse de outrem, ou de toda a sociedade, o que não se dá na hipótese sub judice. Inexistência do direito dos indivíduos heteroafetivos à sua não-equiparação jurídica com os indivíduos homoafetivos. Aplicabilidade do $\S^{\circ}{ }^{\circ}$ do art. $5^{\circ}$ da Constituição Federal, a evidenciar que outros direitos e garantias, não expressamente listados na Constituição, emergem "do regime e dos princípios por ela adotados", verbis: "Os direitos e garantias expressos nesta Constituição não excluem outros decorrentes do regime e dos princípios por ela adotados, ou dos tratados internacionais em que a República Federativa do Brasil seja parte". 5. DIVERGÊNCIAS LATERAIS QUANTO À FUNDAMENTAÇÃO DO ACÓRDÃO. Anotação de que os Ministros Ricardo Lewandowski, Gilmar Mendes e Cezar Peluso convergiram no particular entendimento da impossibilidade de ortodoxo enquadramento da união homoafetiva nas espécies de família constitucionalmente estabelecidas. Sem embargo, reconheceram a união entre parceiros do mesmo sexo como uma nova forma de entidade familiar. Matéria aberta à conformação legislativa, sem prejuízo do reconhecimento da imediata auto-aplicabilidade da Constituição. 6. INTERPRETAÇÃO DO ART. 1.723 DO CÓDIGO CIVIL EM CONFORMIDADE COM A CONSTITUIÇÃO FEDERAL (TÉCNICA DA "INTERPRETAÇÃO CONFORME"). RECONHECIMENTO DA UNIÃO HOMOAFETIVA COMO FAMÍLIA. PROCEDÊNCIA DAS AÇÕES. Ante a possibilidade de interpretação em sentido preconceituoso ou discriminatório do art. 1.723 do Código Civil, não resolúvel à luz dele próprio, faz-se necessária a utilização da técnica de "interpretação conforme à Constituição". Isso para excluir do dispositivo em causa qualquer significado que impeça o reconhecimento da união contínua, pública e duradoura entre pessoas do mesmo sexo como família. Reconhecimento que é de ser feito segundo as mesmas regras e com as mesmas consequências da união estável heteroafetiva." (ADPF 132, Relator(a): Min. AYRES BRITTO, Tribunal Pleno, julgado em 05/05/2011, DJe-198 DIVULG 13-10-2011 PUBLIC 14-10-2011 EMENT VOL-02607-01 PP-00001) 
contudo, não decorre de juízo estritamente técnico, mas da ponderação de valores próprios do intérprete. Isso porque, utilizando-se de técnicas de interpretação da Constituição, o STF emitiu juízo que positivou no ordenamento jurídico nova regra sobre o regime civil de união estável, alterando o preceito legal vigente 9 . Independente da técnica interpretativa que se tenha adotado, a consequência da operação foi a inclusão de nova possibilidade à configuração da entidade familiar decorrente de união estável. Formalmente, pode-se dizer que o juízo constitucional reconheceu a nulidade da leitura literal e restritiva do texto constitucional (até então prevalecente), sem redução do texto da norma (inclusive porque isso não seria possível ${ }^{10}$ ), ou seja, atuando nos limites do espaço de interpretação do elemento textual do dispositivo constitucional ${ }^{11}$, a Corte reconheceu a inconstitucionalidade de uma leitura específica da norma, não condizente com o restante da Constituição..

Olhando para as políticas públicas, ou seja, no conflito entre Judiciário e Executivo, também há muitos exemplos, inclusive porque a situação é recorrente nos tribunais inferiores ${ }^{12}$. Nesse passo, o Min. Joaquim Barbosa, quando da relatoria e voto no RE $634.643 \mathrm{AgR}$, explicita a situação:

Ademais, a jurisprudência desta Corte firmou-se no sentido de que
é permitido ao Poder Judiciário [veja-se que a autorização é
generalizada], em situaçães excepcionais, determinar que a
Administração Pública adote medidas assecuratórias de direitos
constitucionalmente reconhecidos como essenciais sem que isso
configure violação ao princípio da separação de poderes. Nesse
sentido, v.g., RE $417.408-A g R$, rel. Min. Dias Toffoli; RE $665.764-$
AgR, rel. Min. Cármen Lúcia; RE $559.646-$ AgR, rel. Min. Ellen
Gracie; RE 557.086-AgR, rel. Min. Eros Grau; Al 589.398-AgR, rel.
Min. Dias Toffoli; Al $708.667-A g R$, rel. Min. Dias Toffoli.
No presente caso, é inquestionável a relevância social da questão
debatida nos autos, uma vez que se trata de grave situação dos
moradores de rua e da garantia de atendimento em abrigos a

${ }^{9}$ Código Civil. "Art. 1.723. É reconhecida como entidade familiar a união estável entre o homem e a mulher, configurada na convivência pública, contínua e duradoura e estabelecida com o objetivo de constituição de família."

${ }^{10}$ Vide ADI 815

11 Sobre os limites da interpretação, Kelsen já estabelecia o quadro, a moldura de possibilidades interpretativas (2006, pp. 387-397) e Ramos também trata da nulidade qualitativa.

${ }^{12}$ Sobre o controle judicial de políticas públicas há diversos trabalhos jurídicos. Vide, como interessantes abordagens do tema, COMPARATO (1997) e BADIN (2013). 
familiares e pessoas carentes desprovidas do elementar direito à moradia.

O caso que ilustra o exemplo, como se pode notar da transcrição acima, discutia uma ordem judicial para que a Prefeitura Municipal do Rio de Janeiro disponibilizasse mais 65 (sessenta e cinco) vagas em abrigos para moradores de rua. A defesa alegava a prerrogativa do Executivo para identificar as prioridades para o uso do orçamento com políticas públicas (art. $2^{\circ}$ da Constituição, a divisão dos Poderes) e que o gasto, portanto, seria discricionário (violando o art. 167 da Constituição se não previsto em orçamento). Quando no STF, o voto condutor, antes da digressão transcrita acima, entendeu que a discussão seria fáticoprobatória, invocando o verbete № $279^{13}$ da Súmula do STF para fundamentar o descabimento do caso. A ordem para disponibilização das vagas aos moradores de rua - novamente, uma decisão que busca promover justiça ${ }^{14}$ - foi mantida.

Há dois fatos que merecem destaque no caso dos abrigos para moradores de rua. O primeiro é a constatação de que a jurisprudência citada (talvez a mais recente quando do julgamento) esteja repleta de Agravos Regimentais, demonstrando que o tema tende a ser julgado monocraticamente pelos Ministros e levado ao colegiado (Turma ou Plenário) na situação de recurso. Isso demonstra que o STF já reconheceu e de certo modo delegou ao Judiciário como um todo o juízo de oportunidade para a ingerência na função administrativa ${ }^{15}$, podendo os juízes exigir a prestação de determinada política pública em situações concretas sempre no juízo do julgador. Isso leva ao segundo fato: o próprio STF reconheceu a prerrogativa própria ao Judiciário (do qual compõe a cúpula) para interferir nas escolhas políticas do Poder Executivo. Em outros termos, o STF expressamente se

\footnotetext{
13 "Para simples reexame de prova não cabe recurso extraordinário".

${ }^{14}$ Neste caso, ainda há como se questionar se a Justiça é efetiva, já que o número de vagas não aparenta solucionar o problema de moradores de rua sem abrigo, mas apenas de uma situação específica, podendo gerar - e essa é apenas uma hipótese que não foi investigada - problemas de distorção, com algumas localidades, beneficiadas com ações do Ministério Público que restam privilegiadas a outras que, sem a ação do Ministério Público ou outras entidades, não receberão igual atenção e investimento. A diferença está no fato de o primeiro exemplo incidir na função legislativa e, com isso, prover regras de observância geral, enquanto o exemplo de conflito com o Executivo se dá em casos concretos, populações específicas.

${ }^{15}$ Vide a conceituação de Celso Antônio Bandeira de Mello em (2009, p. 36)
} 
intitulou o provedor da última palavra (ou aquele que tem o direito de errar por último, como sugere Mendes ${ }^{16}$ ), tanto nas escolhas legislativas quanto nas políticas, contanto que invocado a se manifestar.

Por óbvio não se está tentando argumentar por uma ditadura do Judiciário, de forma pejorativa, ou qualquer situação do mesmo gênero. Apenas provocar o exercício do raciocínio proposto no voto do Min. Joaquim Barbosa, o que já foi também sugerido por Vilhena (Supremocracia, 2008), conforme acima, e por Karl Loewenstein (1979, pp. 321-325), que alerta sobre os riscos de uma judiciocracia. Levando a situação ao extremo, há que, em relação aos direitos fundamentais sociais $^{17}$ (cláusulas pétreas da Constituição), por exemplo, o Judiciário pode ordenar o Executivo a executar determinada prestação (o que se está chamando de política pública - outro conceito que não se pretende aprofundar), caso entenda a situação como excepcional, o seu critério. Em resposta, o Legislativo pode tentar modificar a legislação ou mesmo emendar a Constituição Federal para reduzir a exposição do Poder Executivo às ordens de universalização desta determinada e hipotética política pública. Contudo, se provocado, o STF poderá reconhecer a inconstitucionalidade da norma editada e, assim, permanecer exigindo a prestação material garantidora do efetivo direito trazido pela Constituição Federal.

O propósito, novamente, não é opinar sobre a adequação ou não desta atuação proativa da Corte constitucional, mas apresentar alguns elementos que demonstram quão fascinante - ao menos para fins teóricos e discussão acadêmica - é a análise da instituição representada pela Corte constitucional e de sua principal função: ser a guardiã da Constituição. Retomando o que foi acima apontado, a evolução do constitucionalismo, isto é, tanto das constituições em si (sobre o quê e como a constituição deve dispor) quanto das Cortes constitucionais (processos de controle de constitucionalidade), foi paulatinamente ampliando o espectro de atuação dos juízes constitucionais, aumentando seus poderes e evidenciando-os à sociedade. Atualmente, como também já exposto, a sociedade espera algo das Cortes constitucionais, razão pela qual é necessário discutir como deve ser 0

\footnotetext{
${ }^{16}$ (2011, pp. 165-170)

${ }^{17}$ Conforme Alexy (2008, pp. 499-519).
} 
diálogo institucional entre os Poderes nesse novo cenário. Não mais buscar a simples retratação dos juízes e cessação de seu protagonismo social. A sociedade conta com o Judiciário e especialmente com a Suprema Corte. Ainda que existam premissas teóricas fundadoras do Estado que imponham limites ao Judiciário, especialmente sob a perspectiva democrática, já que os juízes não são eleitos, do mesmo modo parece não tão democrático suprimir poderes de uma instituição, cuja atuação fora de seus limites teóricos é de alguma forma respaldada pela sociedade. O dilema é de difícil solução.

Discutir sobre o diálogo institucional entre os Poderes e a legitimidade democrática da Corte constitucional é algo que já vem sendo feito por grandes juristas nacionais e estrangeiros. Este trabalho não se propõe a ingressar nessa seara. O foco de atenção desta pesquisa é a decisão judicial, na verdade o conjunto de decisões judiciais ou a jurisprudência do STF. Os questionamentos cujas respostas serão investigadas são menos dogmáticos e, inicialmente, mais pragmáticos. O contexto de discussão e o cenário acima retratado serão assumidos como realidade para os fins deste trabalho.

Outro caso de repercussão relevante no STF colaborará com a introdução mais específica do plano e objetivos deste trabalho. Trata-se da ADPF $46^{18}$. Nessa

18 Outra ementa extensa, mas pertinente para compreensão geral do caso: "EMENTA: ARGÜIÇÃO DE DESCUMPRIMENTO DE PRECEITO FUNDAMENTAL. EMPRESA PÚBLICA DE CORREIOS E TELEGRÁFOS. PRIVILÉGIO DE ENTREGA DE CORRESPONDÊNCIAS. SERVIÇO POSTAL. CONTROVÉRSIA REFERENTE À LEI FEDERAL 6.538, DE 22 DE JUNHO DE 1978. ATO NORMATIVO QUE REGULA DIREITOS E OBRIGAÇÕES CONCERNENTES AO SERVIÇO POSTAL. PREVISÃO DE SANÇÕES NAS HIPÓTESES DE VIOLAÇÃO DO PRIVILÉGIO POSTAL. COMPATIBILIDADE COM O SISTEMA CONSTITUCIONAL VIGENTE. ALEGAÇÃO DE AFRONTA AO DISPOSTO NOS ARTIGOS 1丷, INCISO IV; $5^{\circ}$, INCISO XIII, 170, CAPUT, INCISO IV E PARÁGRAFO ÚNICO, E 173 DA CONSTITUIÇÃO DO BRASIL. VIOLAÇÃO DOS PRINCÍPIOS DA LIVRE CONCORRÊNCIA E LIVRE INICIATIVA. NÃOCARACTERIZAÇÃO. ARGUIÇÃO JULGADA IMPROCEDENTE. INTERPRETAÇÃO CONFORME À CONSTITUIÇẪO CONFERIDA AO ARTIGO 42 DA LEI N. 6.538, QUE ESTABELECE SANÇÃO, SE CONFIGURADA A VIOLAÇÃO DO PRIVILÉGIO POSTAL DA UNIÃO. APLICAÇÃO ÀS ATIVIDADES POSTAIS DESCRITAS NO ARTIGO 9º, DA LEI. 1. O serviço postal --- conjunto de atividades que torna possível o envio de correspondência, ou objeto postal, de um remetente para endereço final e determinado --não consubstancia atividade econômica em sentido estrito. Serviço postal é serviço público. 2. A atividade econômica em sentido amplo é gênero que compreende duas espécies, o serviço público e a atividade econômica em sentido estrito. Monopólio é de 
ação, a ABRAED - Associação Brasileira das Empresas de Distribuição questionou ao STF se a Lei oㅡ 6.538/78 ${ }^{19}$ (por consequência, o Decreto-lei oㅡ 509/6920 também foi discutido) teria sido recepcionada pela Constituição Federal de 1988, considerando as atuais disposições constitucionais sobre a ordem econômica (especialmente $o$ art. 170). Em suma, a ABRAED pretendia que o STF revisasse 0 entendimento, segundo o qual a Empresa Brasileira de Correios e Telégrafos - ECT é prestadora única ${ }^{21}$ das atividades de entrega de correspondências, sendo vedado

atividade econômica em sentido estrito, empreendida por agentes econômicos privados. A exclusividade da prestação dos serviços públicos é expressão de uma situação de privilégio. Monopólio e privilégio são distintos entre si; não se os deve confundir no âmbito da linguagem jurídica, qual ocorre no vocabulário vulgar. 3. A Constituição do Brasil confere à União, em caráter exclusivo, a exploração do serviço postal e o correio aéreo nacional [artigo 20, inciso X]. 4. O serviço postal é prestado pela Empresa Brasileira de Correios e Telégrafos - ECT, empresa pública, entidade da Administração Indireta da União, criada pelo decreto-lei n. 509, de 10 de março de 1.969. 5. É imprescindível distinguirmos o regime de privilégio, que diz com a prestação dos serviços públicos, do regime de monopólio sob o qual, algumas vezes, a exploração de atividade econômica em sentido estrito é empreendida pelo Estado. 6. A Empresa Brasileira de Correios e Telégrafos deve atuar em regime de exclusividade na prestação dos serviços que Ihe incumbem em situação de privilégio, o privilégio postal. 7. Os regimes jurídicos sob os quais em regra são prestados os serviços públicos importam em que essa atividade seja desenvolvida sob privilégio, inclusive, em regra, o da exclusividade. 8. Argüição de descumprimento de preceito fundamental julgada improcedente por maioria. O Tribunal deu interpretação conforme à Constituição ao artigo 42 da Lei n. 6.538 para restringir a sua aplicação às atividades postais descritas no artigo $9^{\circ}$ desse ato normativo." (ADPF 46, Relator(a): Min. MARCO AURÉLIO, Relator(a) p/ Acórdão: Min. EROS GRAU, Tribunal Pleno, julgado em 05/08/2009, DJe-035 DIVULG 25-02-2010 PUBLIC 26-02-2010 EMENT VOL-02391-01 PP-00020 RTJ VOL-00223-01 PP-00011).

${ }^{19}$ A lei dispõe sobre os serviços postais, definidos como "o recebimento, expedição, transporte e entrega de objetos de correspondência, valores e encomendas" (art. $7^{\circ}$, caput), sendo certo que as correspondências compõem: cartas (comunicação escrita, [com ou sem envoltório], de natureza administrativa, social, comercial, ou qualquer outra, que contenha informação de interesse específico do destinatário), cartões-postais (material consistente, sem envoltório, contendo mensagem e endereço), impressos (reprodução obtida sobre material de uso corrente na imprensa, editado em vários exemplares idênticos), cecogramas (impresso em relevo, para uso dos cegos) e pequenas encomendas (objeto de correspondência, com ou sem valor mercantil, com peso limitado, remetido sem fins comerciais). A lei estabelece que os serviços postais são explorados pela União, através de empresa pública (art. $2^{\circ}$ ), sendo crime a violação do privilégio postal da União (art. 42).

20 Decreto-lei que dispõe sobre a transformação do Departamento dos Correios e Telégrafos em empresa pública, e dá outras providências, determina que: "art. $2^{\circ}$. À ECT compete: I - executar e controlar, em regime de monopólio, os serviços postais em todo 0 território nacional; (...)".

${ }^{21}$ Deixa-se para um momento posterior a discussão sobre monopólio das atividades (econômicas) e privilégio do estado na prestação de serviços públicos de forma exclusiva. Esta dicotomia fundamenta a corrente vencedora no julgamento da ADPF 46 e foi liderada 
à iniciativa privada realizar tais atividades (buscava, em termos técnicos, reconhecer a não recepção da legislação que suporta a atuação da ECT). Além disso, pretendia discutir o conceito de "carta", trazido na Lei oㅡ 6.538/78, para restringi-lo ao papel escrito, metido em envoltório fechado, selado, que se envia de uma parte a outra, com conteúdo único, para comunicação entre pessoas distantes contendo assuntos de natureza pessoal e dirigido, produzido por meio intelectual e não mecânico. Nessa definição, buscava excluir expressamente mala-direta, revistas, jornais e periódicos, encomendas, contas de luz, água e telefone e assemelhados, bem como objetos bancários como talões de cheques, cartões de crédito, etc. ${ }^{22}$

As empresas de entrega e distribuição, representadas pela ABRAED, argumentavam que a ordem econômica constituída no Estado brasileiro pela Constituição de 1988 seria clara na defesa da livre iniciativa e concorrência, assim como no livre exercício da atividade econômica, razão pela qual a própria Carta Constitucional traria de forma expressa e taxativa as atividades relegadas ao monopólio estatal ${ }^{23}$. Em sentido contrário, a ECT defende a interpretação do art. 21, X, da Constituição Federal ${ }^{24}$ segundo a qual, o verbo "manter", que caracteriza o dever da União perante o serviço postal, deve ser compreendido sob a premissa de que o serviço postal é um serviço público, cabendo à União, portanto, sua titularidade e a possibilidade de disposição sobre seu regime de prestação. Por

pelo Min. Eros Grau. Ver também sua posição doutrinária anterior ao julgamento (Grau, 2008, pp. 90-153).

${ }^{22}$ Petição inicial e demais documentos destes autos estão disponíveis em: http://www.stt.jus.br/portal/processo/verProcessoAndamento.asp?numero=46\&classe=AD $P F \&$ codigoClasse $=0 \&$ origem $=J U R \&$ recurso $=0 \&$ tipo Julgamento $=M$. Consulta realizada em 25/08/2016.

23 "Art. 177. Constituem monopólio da União: I - a pesquisa e a lavra das jazidas de petróleo e gás natural e outros hidrocarbonetos fluidos; II - a refinação do petróleo nacional ou estrangeiro; III - a importação e exportação dos produtos e derivados básicos resultantes das atividades previstas nos incisos anteriores; IV - o transporte marítimo do petróleo bruto de origem nacional ou de derivados básicos de petróleo produzidos no País, bem assim o transporte, por meio de conduto, de petróleo bruto, seus derivados e gás natural de qualquer origem; V - a pesquisa, a lavra, o enriquecimento, o reprocessamento, a industrialização e o comércio de minérios e minerais nucleares e seus derivados, com exceção dos radioisótopos cuja produção, comercialização e utilização poderão ser autorizadas sob regime de permissão, conforme as alíneas b e c do inciso XXIII do caput do art. 21 desta Constituição Federal."

${ }^{24}$ Art. 21. Compete à União: (...) X - manter o serviço postal e o correio aéreo nacional; (...)". 
isso, a legislação questionada seria legítima e a ECT exerceria regularmente o privilégio sobre tais serviços. O STF, acompanhando voto do Min. Eros Grau, ratificou o entendimento da ECT, atestando que os serviços postais seriam serviços públicos de titularidade da União, sendo que esta deverá organizá-los para assegurar sua universalidade e acessibilidade.

Mas o que é um serviço público? O que a Constituição quer dizer quando menciona "serviço público"? Por que os serviços postais são serviços públicos e os bancos, por exemplo, não o são? O que faz uma atividade ser considerada serviço público? E o que isso quer dizer?

Está claro que a Constituição Federal em momento algum indica expressamente que a União deve, de fato, realizar os serviços postais por meio próprio, muito menos que somente a União ou seu órgão ou entidade prestadora de serviços postais será responsável exclusivo por tais atividades (isso está disposto em lei anterior à Constituição). Por outro lado, também não se diz em local algum o contrário, isto é, que as atividades postais devem ser compreendidas como meras atividades econômicas (em sentido estrito, para adotar a classificação de Eros Roberto $\mathrm{Grau}^{25}$ ) livres ao mercado. De que maneira situações como a ora retratada são resolvidas pelo STF? E como deveriam ser resolvidas idealmente?

A resposta óbvia e mais simples é que o mecanismo de solução perpassa a interpretação da própria Constituição, não se limitando às tiras específicas que tratam dos serviços postais e das atividades econômicas (Grau, Ensaio e Discurso sobre a Interpretação/Aplicação do Direito, 2006), mas compreendendo seu todo, sua essência, a intenção do constituinte ou, como na lição de Dworkin, deveriam ser resolvidas a partir de uma discussão de princípios (Dworkin, 2005, pp. 41-103). A resposta, contudo, não parece precisa o suficiente, pois discute o tema sob o aspecto dogmático, o que é válido e de fundamental importância (inclusive para que se chegasse a esse ponto de questionamento), mas não demonstra se e como essa discussão acontece e, avançando um pouco mais, no que resulta na prática (qual seu output para a sociedade). Definir que a discussão é interpretativa ou

${ }^{25}$ (Grau, 1988, pp. 109-114). 
principiológica apresenta o meio de solução do problema, mas não o resolve. A solução está em cada decisão da Corte. A proposta desta pesquisa, desse modo, é analisar os outputs da Corte, a resposta que dá à sociedade e ao Direito sobre determinado assunto constitucional. Essa resposta, ademais, deve ser compreendida como o conjunto das respostas sobre um determinado tema e não apenas uma resposta isolada em situação específica.

Quando se trata de um aspecto específico, um caso difícil isolado, a compreensão prática da deliberação de princípios (ou deliberação política) é mais simples. Contudo, existem na Constituição diversos direitos e conceitos jurídicos (Grau, 1988, pp. 62-70) que são discutidos não sob apenas um aspecto, mas diversos. Tome-se o exemplo do direito à vida: para se tentar responder à pergunta "O que é o direto à vida no regime jurídico brasileiro?", pode-se partir da leitura da Constituição para dizer que é um direito fundamental (art. 5ㅜ, caput), sua violação é crime sujeito ao júri, a vida não compreende apenas a constatação biológica desse estado, mas a garantia de determinada qualidade de vida (art. 225) e é dever da família também garantir o direito à vida da criança, jovem e adolescente. Enfim, a Constituição dispõe sobre esse direito, mas não o delimita com precisão. Ao discutir o aborto de fetos anencefálicos se está discutindo o direito à vida? A Constituição protege esse direito em relação ao feto? Outro exemplo tradicional: a Constituição protege o direito à vida contra seu próprio titular? É o caso da eutanásia.

Para manter a fidelidade ao exemplo condutor dessa digressão, analisemos os dois argumentos centrais das posições conflitantes da ADPF 46. De um lado, o Ministro Relator, Marco Aurélio, parte de uma leitura histórica do Estado brasileiro e das constituições pretéritas para dizer que o texto reproduzido no art. 21, X, da Constituição de 1988 é mera repetição de disposição já mantida em nossas Cartas desde 1934 (sendo que na Carta de 1891 já se falava em serviços de correios e telégrafos federais). Isso, contudo, não significaria dizer que a leitura desse dispositivo deva ser a mesma desde seus primórdios até o texto atual. A função e importância da entrega de cartas no século XIX é totalmente distinta do que se vê na realidade dos dias de hoje, que é conectada pela internet e sistemas de comunicação dos mais diversos. As cartas, a bem da verdade, são elementos 
históricos, já pouco utilizados no mundo para troca de mensagens entre remetente e receptor. A comunicação é instantânea, imediata, totalmente conectada ${ }^{26}$. Diante disso, o Min. Marco Aurélio propõe uma mutação constitucional ${ }^{27}$ para justificar a leitura do dever de a União manter o serviço postal não mais como historicamente entendido, mas como mera atuação subsidiária, ou seja, suprindo lacunas não atingidas pela iniciativa privada por vontade própria - disso podemos extrair que 0 Ministro sugeria uma atuação subsidiária da ECT ou uma regulação incisiva sobre os serviços postais, garantindo que empresas interessadas pudessem atuar nos mercados mais lucrativos e também suprir a demanda de mercados menos interessantes. A Constituição Federal de 1988, portanto, não teria recepcionado a Lei oㅡ 6.538/78 (por consequência ou, por arrastamento, como diz a jurisprudência do STF, parte do Decreto-lei no 509/69 também não poderia ter sido recepcionada).

Já no voto condutor do julgamento, proferido pelo Min. Eros Grau, tem-se um entendimento muito distinto, que apresenta uma tese doutrinária também defendida pelo então Ministro Eros Roberto Grau. Em sua compreensão, a atividade econômica deve ser vislumbrada como gênero compreendendo duas espécies, o serviço público e a atividade econômica em sentido estrito. O primeiro seria de titularidade e responsabilidade estatais, enquanto a atividade econômica em sentido estrito seria livre à iniciativa privada. Para prestar serviços públicos, portanto, o Estado deveria autorizar os particulares previamente, mas para o Estado atuar na atividade econômica, por seu turno, deveria justificar sua intrusão em bases de segurança nacional ou relevante interesse coletivo. Dessa distinção e do disposto no já repetidas vezes citado art. $21, \mathrm{X}$, o voto condutor entende que os serviços postais são serviços públicos, razão pela qual a prestação de tais atividades por particulares somente seria permitida se o próprio Estado assim

\footnotetext{
26 "Nesse contexto, qual o significado do teor do inciso $X$ do art. 21? Será que o sentido da expressão 'manter o serviço postal' é hoje o mesmo de duzentos anos atrás, quando pelo Alvará de 20 de Janeiro de 1798, instituiu-se que competia aos Poderes Públicos o processo de organização postal dos Correios Terrestres? Será que se está condenado a ficar permanentemente atrelado ao passado, ignorando que o sentido das normas também é condicionado pela evolução da vida, da vida em sociedade? A resposta é desenganadamente negativa, revelando-se um sonoro 'não' (ADPF 26, pp. 27-28).

27 (Barata, 2012, pp. 394-398).
} 
permitisse - daí o chamado regime de privilégio estatal na prestação de serviços públicos, utilizado para contrapor o monopólio alegado e combatido na ação ${ }^{28}$.

\section{Este exemplo serve para ilustrar o problema que a presente pesquisa}

tentou enfrentar: como a Corte constitucional se comporta quando posta a concretizar direitos ou conceitos jurídicos abstratos trazidos pela Constituição Federal $?^{29}$

28 "Tenho reiteradamente insistido na necessidade de apartarmos o regime de privilégio, de que se reverte a prestação dos serviços públicos, do regime de monopólio sob o qual, algumas vezes, a exploração de atividade econômica em sentido estrito é empreendida pelo Estado.

Monopólio é de atividade econômica em sentido estrito. Já a exclusividade da prestação dos serviços públicos é expressão de uma situação de privilégio. RUY BARBOSA afirmava a necessidade de distinguirmos entre o monopólio da atividade econômica (em sentido estrito) e a situação, 'absolutamente diversa, nos seus elementos assim materiais como legais, de outros privilégios, que não desfalcando por modo algum o território do direito individual, confiam a indivíduos ou corporações especiais o exercício exclusivo de certas faculdades, reservadas, de seu natural, ao uso da Administração, no País, no Estado, ou no Município, e por ela delegados, em troco de certas compensações, a esses concessionários privativos'. E, adiante, completa: 'Num ou noutro caso, pois, todos esses serviços hão de ser, necessariamente, objeto de privilégios exclusivos, quer os retenha em se o governo local, quer os confie a executores por ele autorizados. De modo que são privilégios exclusivos, mas não monopólios na significação má e funesta da palavra'. Por quê? Porque se trata da exclusividade da prestação de serviços públicos, que é atividade distinta da atividade econômica em sentido estrito. Por isso digo que o serviço público está para o Estado assim como a atividade econômica em sentido estrito está para o setor privado" (ADPF 46, pp. 70-71 - grifos e destaques no original).

${ }^{29}$ Importante contribuição para a reflexão de qual o propósito da pesquisa proposta foi dada pela Banca de Qualificação, composta pelos Professores Elival da Silva Ramos (orientador), Carlos Bastide Horbach e Rodrigo Pagani de Souza. As provocações apresentadas e a reflexão que delas decorreu foram muito importantes para definir o propósito, o problema principal da pesquisa: verificar, a partir de uma análise ampla das decisões do STF sobre determinado direito ou conceito jurídico, qual o output da Corte sobre aquele instituto. Isto é, se é possível definir o direito ou conceito jurídico em análise a partir das decisões proferidas pelo STF. A escolha pelos serviços públicos, deste modo, foi uma opção do pesquisador tomada ao início da pesquisa, assumindo como hipótese que este seria um instituto interessante para a pesquisa da forma como proposta, haja vista a recorrência de discussões sobre o tema, a possibilidade de delimitação da pesquisa com critérios objetivos, dentre outros aspectos melhor apresentados ao longo deste trabalho. Também não tomo como objetivo principal a utilização de métodos quantitativos na pesquisa jurisprudencial, posto que isso seria pretensão demasiada para este momento, inclusive pela falta de conhecimento estatístico para a realização de um trabalho sofisticado o suficiente para o tipo de pesquisa atualmente realizada. A proposta, portanto, pode ter se tornado mais modesta, o que não retira sua pertinência. 
A Constituição Federal brasileira pode ser classificada como rígida, analítica e dirigente (Moraes, 2008, pp. 10-11). Isto quer dizer que a ordem constitucional brasileira, topo de nosso ordenamento jurídico ${ }^{30}$, disciplina muitos temas (alguns até de forma desnecessária ou com excesso de regulamentação). Tais temas abundantes ainda são regulados de forma programática (prospectando situações futuras ${ }^{31}$ ) e sua alteração no plano constitucional é difícil, exigindo aprovação do Congresso Nacional em quórum qualificado (três quintos dos membros) e após dois turnos de votação. Assim, não é incomum se deparar com situações nas quais valores constitucionais ou princípios entram em conflito ${ }^{32}$. Do mesmo modo, também nos deparamos com situações nas quais o texto constitucional é aberto, vago ou comporta interpretações bastante aceitáveis, mas em caminhos diametralmente opostos.

Os serviços públicos integram esse rol de situações constitucionais abstratas ou abertas. Nas palavras de Eros Roberto Grau (1988, p. 109):

O exercício de preenchimento do conceito de 'serviço adequado' envolveu a consideração de dados da realidade. Há outros, no entanto, como anteriormente observei, cujo preenchimento é de ser empreendido mediante a consideração de concepções políticas predominantes, concepções essas que variam conforme a atuação das forças sociais.

Para exemplificar, em torno dessas hipóteses, tomarei agora dos conceitos de atividade econômica e de serviços públicos.

À frente, constata (1988, p. 111):

De outra parte, a tentativa de defini-lo [serviço público] como 'atividade sujeita ao regime de serviço público' é também de todo improfícua.

E isso, por um lado, em razão de inexistir 'uma totalidade normativa que se possa referir como regime de serviço público, tal como penso também ter demonstrado em oportunidades anteriores.

Por outro lado, em virtude de, ao afirmar-se que atividade de serviço público é aquela desempenhada em regime de serviço público, perpetrar-se indesculpável tautologia, além do mais privilegiando-se a forma, em detrimento do conteúdo.

Uma atividade determinada fica sujeita a regime de serviço público porque é serviço público e não, como muitos enganosamente

${ }^{30}$ (Kelsen, 2006, pp. 246-249).

31 (Miranda, 1996, pp. 243-246).

32 (Alexy, 2008, pp. 93-103). 
propõem, passa a ser tida como serviço público porque a ela aplicado regime de serviço público.

Então, o que é serviço público? Dizer que determinada atividade é serviço público simplesmente porque assim o é não resolve a indeterminação da noção ${ }^{33}$ de serviço público. A conclusão é pelo reconhecimento do desafio diuturno de concretização do serviço público, acompanhando a realidade em que inserido (Grau, 1988, p. 114):

Diante desse quadro desnuda-se como extremamente complexa a tarefa de preenchimento dos conceitos de iniciativa econômica e de serviço público, sempre que nos incumbe aplicar um ou outro a determinada situação. Nem mesmo o recurso à consideração do estado do jogo de classes contribuirá eficazmente, em determinados casos, para a supressão dessa complexidade. Em tais casos limite, porém, teremos também inteiramente desnudado, em seu papel eficientemente desempenhado, de transformação da luta em jogo, o próprio Direito.

A crítica que se pode fazer à proposta de pesquisa, nesse passo, é que os serviços públicos não teriam sua definição literalmente expressa na Constituição por opção consciente do Poder Constituinte originário, deixando margem ao legislador ordinário para deliberação, feitas apenas algumas ressalvas sobre os serviços públicos essenciais, já definidos pela Constituição Federal (Bandeira de Mello C. A., 1979, pp. 22-23). Quanto a esse ponto, assumiu-se a hipótese de que - STF, embora diante da delegação do tema à legislação ordinária, tem papel relevante na utilização da noção e definição do regime jurídico do serviço público. Assim, não se imagina que o conjunto de decisões do STF sobre o tema permita que se extraia um conjunto de enunciados normativos que definirão claramente 0 que é um serviço público e seu regime jurídico constitucional. O propósito aqui será a realização de um retrato da jurisprudência do STF sobre serviços públicos e sob a égide da Constituição de 1988. Esse quadro, contudo, não será tomado como um conjunto normativo ${ }^{34}$, mas como fatos concretos a serem analisados e testados, na

\footnotetext{
${ }^{33}$ Tendo em vista a cambialidade do conteúdo do serviço público, não se fala em conceito de serviços públicos e sim na sua noção. Vide Duguit (2007, pp. 28-31) e Grau (2008, pp. 132-135).

${ }^{34}$ Nosso sistema de civil law nem permitiria que fizéssemos essa assunção direta, pois ainda que se atribua efeito vinculante às decisões do STF, proferidas em controle abstrato de constitucionalidade, tanto essas decisões podem ser revertidas pela própria Corte,
} 
tentativa de responder a questionamentos como: (i) o que o STF já decidiu sobre serviço público? Ao consolidar essas decisões, é possível montar um quadro jurídico-constitucional dos serviços públicos? Como seria este quadro?; (ii) há coerência nas decisões?; (iii) quais atividades foram consideradas serviços públicos?; (iv) o termo serviços públicos aparece na jurisprudência (e na Constituição) sempre com o mesmo sentido?; enfim, (v) o tema dos serviços públicos é constitucional e relevante para o STF?

Para tentar construir caminhos para responder a alguns dos questionamentos apresentados até aqui, o trabalho está organizado em três partes, cada qual voltada a um determinado momento da pesquisa. Na primeira parte, composta por cinco capítulos, pretende-se apresentar a pesquisa, isto é introduzir seu problema e estruturar uma base conceitual para todo o trabalho. A segunda parte, com quatro capítulos, é voltada ao desenvolvimento da pesquisa (especialmente da pesquisa jurisprudencial ora proposta), apresentando a delimitação do universo de pesquisa, a metodologia e o relato de seu desenvolvimento. Além disso, a segunda parte também apresentará a organização dos resultados, isto é, a preparação do resultado descritivo da compilação de dados que serão extraídos da análise jurisprudencial que fundamenta este trabalho.

Como o propósito aqui não se limita à descrição de resultados da análise jurisprudencial, partindo à obtenção de outras respostas a partir da rica base de dados que se pretende construir, a terceira parte, composta por quatro capítulos, se dedicará exclusivamente a est finalidade. O ponto de partida será a apresentação, se possível, do panorama jurídico-constitucional dos serviços públicos, tentando responder questões desenvolvidas ou suscitadas ao longo do

quanto o Legislativo pode emendar a Constituição e pacificar o assunto. Fora isso, a jurisprudência da Corte possui diversos julgados (a maior parte do todo) no exercício do controle concreto de constitucionalidade ou, ainda, no exercício de outras competências jurisdicionais que a Constituição atribuiu ao STF, tornando a Corte um modelo próprio de jurisdição constitucional somada a diversas outras atribuições não comuns nos modelos de tribunais constitucionais europeus ou mesmo da Suprema Corte estadunidense (Moraes, 2000, pp. 219-223). A bem da verdade, pode-se dizer que sequer o sistema de common law, dotado do stare decisis, poderia assumir que o conjunto de decisões da Corte constitucional representa um quadro normativo rígido, dada a possibilidade de reversão das decisões pelo próprio Judiciário (Leal, 2006, pp. 127-129) - a questão reside no ônus de justificação para reversão das decisões. 
trabalho. Por essas circunstâncias, este trabalho não pode ser compreendido como um resultado final de um projeto. É, ao invés, mais uma pequena contribuição para o estudo e diálogo sobre a jurisdição constitucional e o papel das Cortes constitucionais, com a proposta de utilizar uma perspectiva de análise fundada nos outputs do STF, ou seja, pretende-se estudar o Direito Constitucional a partir dos resultados de sua interpretação e aplicação realizadas pela Corte constitucional é o direito instituído nas decisões do STF retroalimentando o próprio direito vigente. O trabalho também construiu um banco de dados com informações sobre todas as decisões aqui analisadas, outro passo inicial para novas pesquisas e cruzamentos de dados.

A inclinação da pesquisa, portanto, é para uma visão realista ${ }^{35}$ da jurisprudência constitucional e os serviços públicos foram o tema escolhido para esta investigação. Portanto, não se trata de uma obra aprofundada na teoria dos serviços públicos. O tema de pesquisa, o núcleo constitucional escolhido para centralizar a pesquisa empírica, poderia ser outro, como a utilização de um direito fundamental específico (direito à vida, à igualdade, liberdade de reunião), um princípio selecionado, a utilização de um dispositivo ou artigo da Constituição Federal ou outra noção ou conceito cuja discussão seja interessante.

Os serviços públicos, no entanto, foram escolhidos por trazerem características interessantes para a pesquisa. Relevado o interesse pessoal do pesquisador pelo assunto e a curiosidade em compreender como a jurisprudência constitucional se comportava em face ao uso dos serviços públicos, a noção ainda beneficia a pesquisa por ser um tema de aplicação relativamente bem delimitada, que poderia estar presente em um número relevante de decisões da Corte, mas com um recorte de certo modo coerente. Por outro lado, a carga de valores que os serviços públicos carregam poderia dificultar a identificação de razões e fundamentos claros para as decisões proferidas pela Corte.

${ }^{35}$ Compreende-se o realismo jurídico - escola de longa data na tradição estadunidense por ora, como sugerido por Roscoe Pound (1931). Ver também Osmo (2008) e Nunes (2016). 


\section{CONSIDERAÇÕES FINAIS}

O capítulo final deste trabalho foi reservado não para resumir toda a trajetória até aqui já descrita, mas para comentar esse difícil paradoxo dos serviços públicos, que podem caminhar para um desuso, mas se manter firmes na Constituição nas falas sobre o Direito. Não fossem tais serviços relevantes - ou, ao menos, se este pesquisador assim não os julgasse - este trabalho representaria perda inquestionável de tempo e esforços. Mas a compreensão de serviços públicos ainda é fundamental para o entendimento do Estado e, em especial, do Estado brasileiro.

Devemos reconhecer que os serviços públicos são, de forma geral, aceitos pela sociedade como aquelas atividades que julgamos essenciais, que queremos que o Estado nos garanta, seja porque meramente pensamos assim ou porque a própria Constituição nos sugeriu. A questão central é que esses serviços públicos carregam uma carga ideológica que opõe diametralmente alguns estudiosos e permite compreensões muito distintas sobre suas próprias bases e preceitos. É por isso, inclusive, que a tendência parece ser o enxugamento dos serviços públicos e seu contorno com outros critérios ou conceitos.

A carga ideológica que os serviços públicos carregam trazem o risco da instabilidade jurídica, pois as divergências são muitas. Esse até pode ser um motivo para não se aprofundar em demasia na discussão do serviço público no tribunal constitucional, já que o custo desse debate seria alto. Há exemplos de aprofundamentos em casos específicos, como o sempre mencionado caso dos Correios, mas vê-se que as consequências eram conhecidas e bem delimitadas. Como sugeriu Pound no trecho citado no início do capítulo anterior, talvez a melhor alternativa seja deixar o preciosismo conceitual de lado e buscar a solução jurídica dos problemas que afetam os serviços públicos de verdade. Criar limitações conceituais rígidas no Direito - especialmente nesse campo - pode se tornar mais um empecilho à garantia das prestações demandadas pela sociedade do que um meio de as garantir, como propõem aqueles que pregam pelo rigor terminológico. 
A pesquisa desenvolvida neste trabalho ajudou o autor a compreender e melhor enxergar como um instituto específico se comporta dentro da Suprema Corte Brasileira. O trabalho serviu como um destacamento de dentro da Corte e permitiu o entendimento mais profundo e esclarecedor da efetiva jurisprudência, o conjunto de julgados que, inevitavelmente, está relacionado e conectado pelo fio condutor, neste caso, dos serviços públicos. O experimento, no entanto, pode ser feito com outros institutos da Constituição ou de outras normas e poderá enriquecer bastante o estudo das Cortes e de seus respectivos comportamentos.

A pesquisa ainda gerou muitos outros dados e informações valiosas, boa parte delas aberta à consulta e pesquisa nos documentos anexos a este trabalho. O desejo é que este seja um material de princípio, viabilizando outras pesquisas e análises a partir do banco de dados ora construído, parte integrante da pesquisa e com grande valor de informações.

Sobre a atuação do STF, por fim, a pesquisa demonstrou que em relação aos serviços públicos está dividida entre os casos em que a Corte agiu e construiu alguma jurisprudência e os temas que deixou de atuar (deixou de decidir), preferindo relegar a tarefa de solucionar a divergência à sociedade. Em resumo, minha reflexão pessoal sobre a utilização dos serviços públicos pelo STF é a de que, por um lado, a opção por utilizar os serviços públicos como fundamento de uma decisão é uma escolha difícil e tomada, em regra, apenas quando estritamente necessária para configurar uma situação almejada pelo julgador. Os serviços públicos, pois, são utilizados como bengalas para apoiar entendimentos que não poderiam ser justificados sob outro manto. Por essa razão, inclusive, que a Saúde e a Educação apareceram pouco na pesquisa, já que outros mantos valorativos permitiam ao STF chegar à decisão almejada sem invocar os serviços públicos. Por outro lado, a Corte é eloquente ao também deixar de decidir sobre os serviços públicos. Em temas de grande repercussão, como leis gerais para setores considerados serviços públicos, o STF prefere não decidir ou postergar suas deliberações para que a sociedade crie meios próprios ou mesmo se adéque previamente ao comando do tribunal. Seja pelos impactos econômicos que, talvez, os Ministros não queiram assumir sozinhos a responsabilidade de tê-los criado ou mesmo pelo possível embate de valores e ideologias que a discussão sobre os 
serviços públicos traz consigo, o STF decide não decidir em grandes temas dos serviços públicos. Esse é mais um exemplo do silêncio eloquente e bastante orientador da posição do tribunal (Poder Judiciário) perante temas antes ideológicos (políticos) que jurídicos. 


\section{BIBLIOGRAFIA}

ABRAMO, P. Pesquisa em Ciências Sociais. In: HIRANO, S. Pesquisa Social. Projeto e Planejamento. São Paulo: T.A. Queiroz, 1979. p. 21-88.

AGUILlAR, F. H. Controle Social de Serviços Públicos. São Paulo: Max Limonad, 1999.

ALEXY, R. Teoria dos Direitos Fundamentais. São Paulo: Malheiros, 2008.

ANDERSON IV, R.; TAHK, A. M. Institutions and Equilibrium in the United States Supreme Court. The American Political Science Review, v. 101, n. 4, p. 811-825, Nov. 2007. Disponivel em: <http://www.jstor.org/stable/27644486>.

ANDERSON, W. H. The Supreme Court and Recent Public Utility Valuation Theory. The Journal of Land \& Public Utility Economics, v. 21, n. 1, p. 12-22, Fev 1945. ARAGÃO, A. S. D. Direito dos serviços públicos. 3a․ ed. Rio de Janeiro: Forense, 2013.

ATALIBA, G. Hipótese de incidência tributária. 6a․ ed. São Paulo: Malheiros, 2009.

BACHOF, O. Normas constitucionais inconstitucionais? Coimbra: Almedina, 2008.

BADIN, A. S. Controle judicial das políticas públicas: contriuição ao estudo do tema da judicialização da política pela abordagem da análise institucional comparada de Neil K. Komesar. São Paulo: Malheiros, 2013.

BANDEIRA DE MELLO, C. A. Natureza e regime jurídico das autarquias. São Paulo: Revista dos Tribunais, 1968.

BANDEIRA DE MELLO, C. A. Prestação de serviços públicos e administração indireta. 2a . ed. São Paulo: Revista dos Tribunais, 1979.

BANDEIRA DE MELLO, C. A. Curso de Direito Administrativo. 26ạ. ed. São Paulo: Malheiros, 2009.

BANDEIRA DE MELLO, O. A. Princípios Gerais de Direito Administrativo. 2ª ed. São Paulo: Malheiros, v. 1: Introdução, 2007.

BARATA, R. S. A mutação constitucional e o STF. In: VOJVODIC, A., et al. Jurisdição constitucional no Brasil. São Paulo: Malheiros, 2012. p. 386-404.

BARROSO, L. R. A razão sem voto: o Supremo Tribunal Federal e o governo da maioria. Revista Brasileira de Políticas Públicas, Brasília, v. 5, n. Especial, p. 2350, 2015.

BAUER, J. Important public utility decisions by the Supreme Court and their public implications. The Journal of land \& popular utility economics, v. 14, n. 1, p. 1-9, Fev 1938. 
BOBBIO, N. Liberalismo e Democracia. 3ạ. ed. São Paulo: Brasiliense, 1990.

BONAVIDES, P. Curso de direito constitucional. 22ª ed. São Paulo: Malheiros, 2008.

BUCCI, M. P. D. Fundamentos para uma Teoria Jurídica das Políticas Públicas. São Paulo: Saraiva, 2013.

CAPPELLETTI, M. A Controle Judicial de Constitucionalidade das Leis no Direito Comparado. 2ª ed. Porto Alegre: Fabris, 1999.

CARRAZZA, R. A. Curso de Direito Constitucional Tributário. 24ㄹa ed. São Paulo: Malheiros, 2008.

CARVALHO, V. M. D. O Direito do Saneamento Básico - Coleção Direito Econômico e Desenvolvimento. São Paulo: Quartier Latin, v. 1, 2010.

CLAYTON, C. W. The Supreme Court and Political Jurisprudence: new and old instituttionalism. In: CLAYTON, C. W.; GILLMAN, H. Supreme Court DecisionMaking: New Institutionalist Approaches. Chicago: The University of Chicago Press, 1999.

COASE, R. H. The nature fo the Firm. In: COASE, R. H. The Firm, the Market and the Law. Chicago: The Chicago University Press, 1988. p. 33-56.

COASE, R. H. The problem of social cost. In: COASE, R. H. The Firm, the Market and the Law. Chicago: The University of Chicago Press, 1988. p. 95-156.

COMPARATO, F. K. Ensaio sobre o juízo de constitucionalidade de políticas públicas. In: BANDEIRA DE MELLO, C. A. Estudos em Homenagem a Geraldo Ataliba: Direito Administrativo e Constitucional. São Paulo: Malheiros, 1997. p. 343369.

CONRADO, R. D. S. Serviços Públicos à brasileira: fundamentos jurídicos, definição e aplicação. São Paulo: Saraiva, 2013.

COOTER, R.; ULEN, T. Direito \& Economia. 5ª . ed. Porto Alegre: Bookman, 2010.

COUTINHO, D. R. Direito, Desigualdade e Desenvolvimento. São Paulo: Saraiva, 2013.

DAL POZZO, A. N. Aspectos fundamentais do serviço público no direito brasileiro. São Paulo: Malheiros, 2012.

DUGUIT, L. Las Transformaciones del Derecho Público y Privado. Granada: Comares, 2007.

DURKHEIM, E. De la división del trabajo social. 2ª ed. Buenos Aires: Schapire, 1967.

DWORKIN, R. Equality, Democracy, and Constitution: we the people in court. Alberta Law Review, Alberta, v. XXVIII, No. 2, p. 324-346, 1989-1990.

DWORKIN, R. Uma questão de princípio. São Paulo: Martins Fontes, 2005. 
EPSTEIN, L.; GEORGE, T. E. On the Nature of Supreme Court Decision Making. The American Political Science Review, v. 86, n. 2, p. 323-337, Jun. 1992. Disponivel em: <http://www.jstor.org/stable/1964223>.

FARIA, J. E. O Direito na Economia Globalizada. São Paulo: Malheiros, 2004.

FERREIRA FILHO, M. G. Comentários à Constituição brasileira de 1988. São Paulo: Saraiva, 1990.

GORDILLO, A. Tratado de Derecho Administrativo. 5‥ ed. Belo Horizonte: Del Rey, v. 2, 2003.

GRAU, E. R. Direito, conceitos e normas jurídicas. São Paulo: Revista dos Tribunais, 1988.

GRAU, E. R. Constituição e serviço público. In: GRAU, E. R.; GUERRA FILHO, W. S. Direito Constitucional: estudos em homenagem a Paulo Bonavides. São Paulo: Malheiros, 2003. p. 249-267.

GRAU, E. R. Ensaio e Discurso sobre a Interpretação/Aplicação do Direito. 4ạ . ed. São Paulo: Malheiros, 2006.

GRAU, E. R. A Odem Econômica na Constituição de 1988. 13a‥ ed. São Paulo: Malheiros, 2008.

GROTTI, D. A. M. O serviço público e a Constituição brasileira de 1988. São Paulo: Malheiros, 2003.

HARTMANN, I. A.; CHADA, D. A Razão sem Condições de Qualidade. In: VILHENA, O. Coletânea Organizada pela FGV Direito São Paulo com trabalhos que discutem o artigo "A Razão Sem Voto: O Supremo Tribunal Federal e o Governo da Maioria", de Luís Roberto Barroso. [S.I.]: [s.n.], 2015. Disponivel em: <http://ssrn.com/abstract=2689294>.

HAURIOU, M. A teoria da Instituição e da Fundação: ensaio de vitalismo social. Porto Alegre: [s.n.], 2009.

HOENNIGE, C. et al. Veto Players, Veto Bargaining and Constitutional Courts: Theoretical Considerations and Empirical Lessons. Disponível em SSRN: http>//ssrn.com/abstract=2739927 ou http://dx.doi.org/10.2139/ssrn.2739927, Feb 2016.

HOLMES, O. W. The path of the law. Harvard Law Review, v. 457, n. 10, 1897.

HOLMES, S.; SUNSTEIN, C. R. The cost of rights: why liberty depends on taxes. Nova lorque: Norton \& Company, 1999.

JÈZE, G. Principios Generales des Derecho Administrativo. Buenos Aires: Depalma, v. II-1, 1949.

JUSTEN FILHO, M. Serviço público no direito brasileiro. In: AUTORES, V. Curso de direito administrativo econômico. São Paulo: Malheiros, v. I, 2006. p. 375407. 
JUSTEN, M. S. A noção de serviço público no direito europeu. São Paulo: Dialética, 2003.

KATZ, D. M.; BOMMARITO, M. J.; BLACKMAN, J. Predicting the Behavior of the Supreme Court of the United States: A General Approach, 21 Julho 2014. Disponivel em: <http://ssrn.com/abstract=2463244>. Acesso em: 2016.

KELSEN, H. Teoria pura do direito. 7ª ed. São Paulo: Martins Fontes, 2006.

LEAL, R. S. O efeito vinculante na jurisdição constitucional. São Paulo: Saraiva, 2006.

LIM, B. Y. An Empirical Analysis of Supreme Court Justices' Decision Making. The Journal of Legal Studies, v. 29, n. 2, p. 721-752, Jun. 2000. Disponivel em: <http://www.jstor.org/stable/10.1086/468091>.

LIMA, C. M. M. A. Regime jurídico dos portos marítimos. São Paulo: Verbatim, 2011.

LIMA, R. C. Princípios de Direito Administrativo. 7a. ed. São Paulo: Malheiros, 2007.

LOEVINGER, L. Jurimetrics: The Methodology of Legal Inquiry. Law and Contemporary Problems, v. 28, n. 1, p. 5-35, 1963. Disponivel em: <http://www.jstor.org/stable/1190721>.

LOEWENSTEIN, K. Teoría de la Constituición. 2ª . ed. Barcelona: Ariel, 1979.

MALTZMAN, F.; SPRIGGS II, J. F.; WAHLBECK, P. J. Strategy and Judicial Coice: New Institutionalist Approaches to Supreme Court Decision-Making. In: CAYTON, C. W.; GILLMAN, H. Supreme Court Decision-Making: New Institutionalist Approaches. Chicago: The university of Chicago Press, 1999. p. 43-63.

MARQUES NETO, F. D. A. Direito das Telecomunicações e ANATEL. In: SUNDFELD, C. A. Direito administrativo econômico. São Paulo: Malheiros, 2006. p. 300-316.

MASCARENHAS, R. T. D. A. Direito das Telecomunicações. Belo Horizonte: Fórum, 2008.

MEDAUAR, O. Serviço Público. Revista de Direito Administrativo, Rio de Janeiro, v. 189, p. 100-113, Jul-Set. 1992.

MENDELSON, W. The Untroubled World of Jurimetrics. The Journal of Politics, Chicago, v. 26, n. 4, p. 914-922, Nov. 1964. Disponivel em: <http://www.jstor.org/stable/2128233>.

MENDELSON, W. An Open Letter to Professor Spaeth and his Jurimetrical Colleagues. The Journal of Politics, Chicago, v. 28, n. 2, p. 429-432, May 1966. Disponivel em: <http://www.jstor.org/stable/2127558>.

MENDES, C. H. Controle de constitucionalidade e democracia. Rio de Janeiro: Elsevier, 2008. 
MENDES, C. H. Direitos fundamentais, separação de poderes e deliberação. São Paulo: Saraiva, 2011.

MENDES, C. H. Constitutional Courts and Deliberative Democracy. Oxford: Oxford University Press, 2013.

MENDES, G. F. O papel do Senado Federal no controle de constitucionalidade: um caso clássico de mutação constitucional. Revista de Informação Legislativa, Brasília, v. 162, p. 149-168, Abr-Jun 2004.

MENDES, G. F. Estado de DIreitro e Jurisdição Constitucional - 2002-2010. São Paulo: Saraiva, 2011.

MIRANDA, J. Manual de Direito Constitucional. $3^{a}$. ed. Coimbra: Coimbra, v. II, 1996.

MONTEIRO, J. V. Lições de Economia Constitucional Brasileira. Rio de Janeiro: Editora FGV, 2004.

MORAES, A. D. Jurisdição Constitucional e Tribunais Constitucionais; Garantia suprema da constituição. São Paulo: Atlas, 2000.

MORAES, A. D. Direito Constitucional. 23å. ed. São Paulo: Atlas, 2008.

NEVES, M. Transconstitucionalismo. São Paulo: Martins Fontes, 2013.

NORTH, D. C. Institutions, Institutional Change and Econnomic Performance. São Paulo: Cambridge University Press, 1990.

NUNES, A. J. A.; SCAFF, F. F. Os Tribunais e o Direito à Saúde. Porto Alegre: Livraria do Advogado, 2011.

NUNES, M. G. Jurimetria aplicada ao direito societario: um estudo estatistico da dissolucao de sociedade no Brasil. São Paulo: Tese de Doutorado apresentada à PUC/SP, 2012.

NUNES, M. G. Jurimetria: como a estatística pode reinventar o Direito. São Paulo: Revista dos Tribunais, 2016.

OSMO, C. O realismo jurídico norte-americano: uma reflexão sobre a vinculação do juiz constitucional ao direito positivo. São Paulo: Tese de Doutorado defendida na PUC/SP, 2008.

OST, F. O tempo do direito. Bauru: EDUSC, 2005.

PINHEIRO, A. C.; SADDI, J. Direito, economia e mercados. Rio de Janeiro: Elsevier, 2005.

POSNER, R. A. How Judges Think. Cambridge: Harvard University Press, 2008.

POUND, R. The call for a Realist Jurisprudence. Harvard Law Review, v. 44, n. 5, p. 697-711, Mar 1931. Disponivel em: <http://www.jstor.org/stable/1331791>.

RAMOS, E. D. S. Ativismo Judicial: parâmetros dogmáticos. São Paulo: Saraiva, 2010. 
REALE, M. Lições Preliminares de Direito. 27ª̣. ed. São Paulo: Saraiva, 2006.

REALE, M. O direito como experiência. 2a . ed. São Paulo: Saraiva, 2010.

REALE, M. O Direito como Experiência. 2a․ ed. São Paulo: Saraiva, 2010.

RICHARDS, M. J.; KRITZER, H. M. Jurisprudential Regimes in Supreme Court Decision Making. The American Political Science Review, v. 96, n. 2, p. 305-320, Jun. 2002. Disponivel em: <http://www.jstor.org/stable/3118027>.

ROSENBAUM, I. S.; LILIENTHAL, D. National Courts and Local Utilities. The Journal of Land \& Public Utility Economics, v. 4, n. 3, p. 318-320, Ago 1928.

SALAMA, B. M. Direito e economia: textos escolhidos. São Paulo: Saraiva, 2010.

SANDEL, M. J. Justiça - O que é fazer a coisa certa. Rio de Janeiro: Civilização Brasileira, 2011.

SARLET, I. W. A eficácia dos Direitos Fundamentais: uma teoria geral dos direitos fundamentais na perspectiva constitucional. 11a․ ed. Porto Alegre: Livraria do Advogado, 2012.

SCAFF, F. F. Direito à Saúde e os Tribunais. In: NUNES, A. J. A.; SCAFF, F. F. Os Tribunais e o Dlreito à Saúde. Porto Alegre: Livraria do Advogado, 2011. Cap. II, p. 73-135.

SCHUBERT, G. Behavioral Jurisprudence. Law \& Society Review, v. 2, n. 3, p. 407-428, May 1968. Disponivel em: <http://www.jstor.org/stable/3052896>.

SCHUBERT, G. Subcultural Effects on Judicial Behavior: A Comparative Analysis. The Journal of Politics, v. 42, n. 4, p. 951-992, Nov. 1980. Disponivel em: $<$ http://www.jstor.org/stable/2130733>.

SCHWARTZ, B. A History of the Supreme Court. Oxford: Oxford University Press, 1993.

SHAPIRO, C. Coding Complexity: Bringing Law to the Empirical Analysis of the Supreme Court. Hastings Law Journal, v. 60, p. 477-540, Maio 2008. Disponivel em: <http://ssrn.com/abstract=998639>.

SILVA, J. A. D. Aplicabilidade das normas constitucionais. 8a․ ed. São Paulo: Malheiros, 2012.

SILVA, V. A. D. Direitos Fundamentais: conteúdo essencial, restrições e eficácia. São Paulo: Malheitos, 2009.

SOUTO, M. J. V. Desestatização, privatização, concessões e terceirizações. Rio de Janeiro: Lumen Juris, 2000.

SOUZA, R. P. D. Repercussão Geral no Supremo Tribunal Federal (STF). In: CUNHA, A. D. S.; SILVA, P. E. A. D. Pesquisa empírica em direito. Ribeirão Preto: Ipea, 2013. p. 387-404. 
SUNDFELD, C. A. Introdução às Agências Reguladoras. In: SUNDFELD, C. A. Direito Administrativo Econôomico. São Paulo: Malheiros, 2006. Cap. 2, p. 1738.

SUNDFELD, C. A. Introdução às Agências Reguladoras. In: SUNDFELD, C. A. Direito administrativo econ^^mico. São Paulo: Malheiros, 2006. Cap. 2, p. 17-38.

TÁCITO, C. Temas de direito público: (estudos e pareceres). Rio de Janeiro: Renovar, 1997.

ULMER, S. S. Dissent Behavior and the Social Background of Supreme Court Justices. The Journal of Politics, v. 32, n. 3, p. 580-598, Aug. 1970. Disponivel em: <http://www.jstor.org/stable/2128832>.

VENÂNCIO FILHO, A. A intervenção do estado no domínio econômico: o direito público econômico no Brasil. Rio de Janeiro: Renovar, 1998.

VIEIRA, O. V. Supremocracia. Revista Direito GV, São Paulo, Jul-Dez 2008. 441464.

VOJVODIC, A. D. M. Nos labirintos do STF: em busca do conceito de serviço público. São Paulo: Monografia apresentada na Sociedade Brasileira de Direito Público, 2006.

WALDRON, J. The Core of the Case Against Judicial Review. The Yale Law Journal, v. 115, p. 1346-1406, 2006.

WILLIAMSON, O. E. The economic institutions of capitalism. Nova lorque: Free Press, 1985. 


\section{ANEXO I - BANCO DE ACÓRDÃOS}

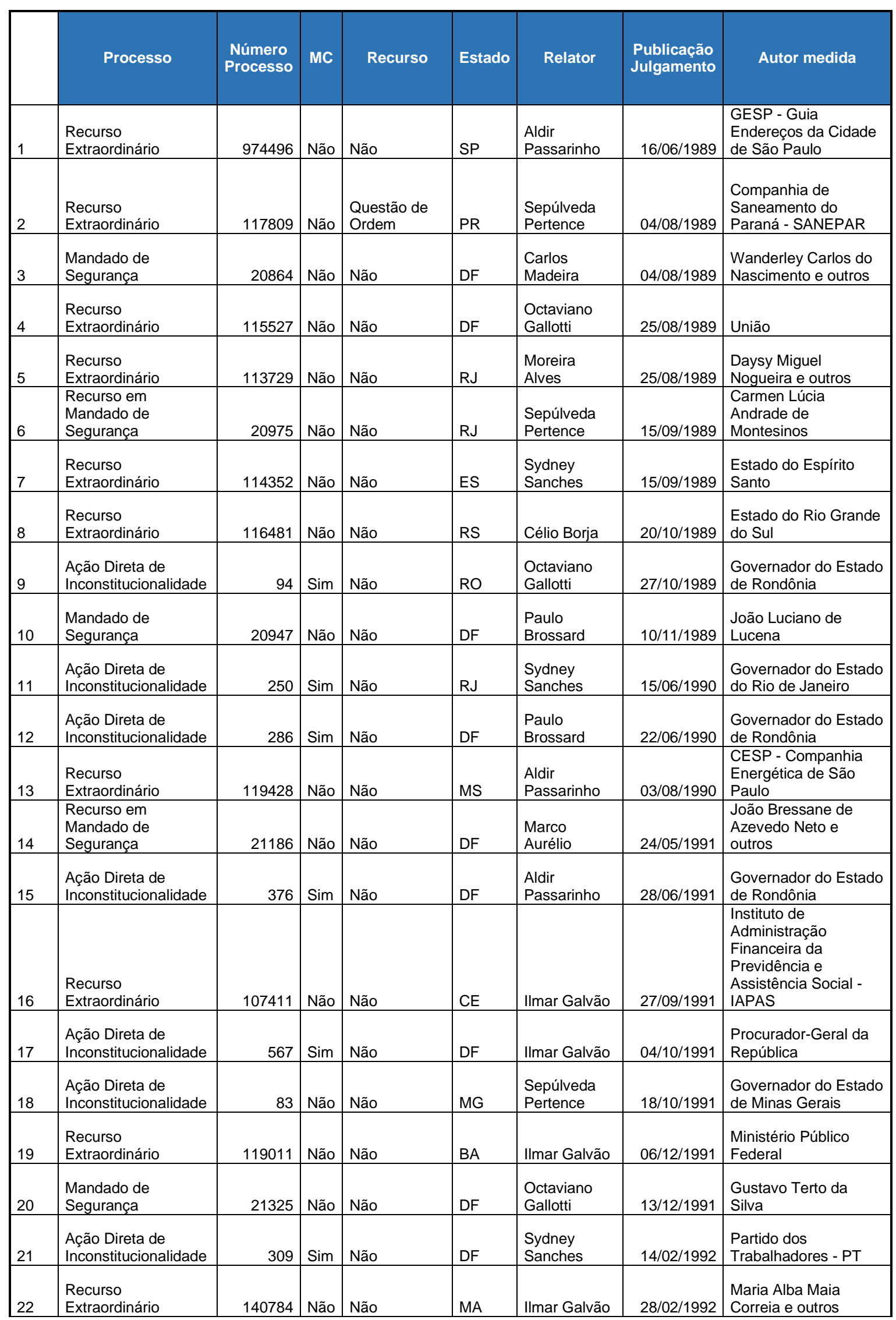




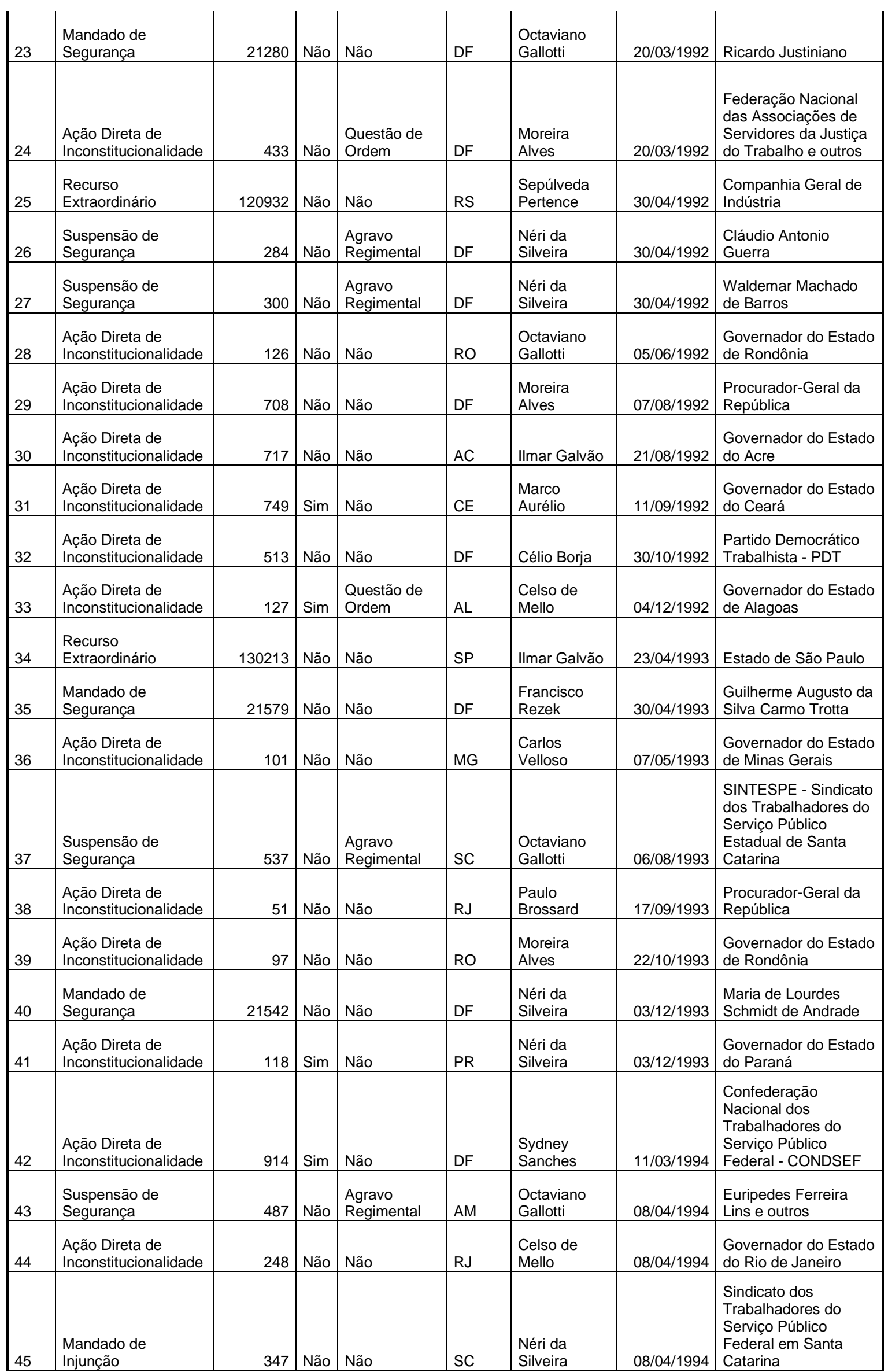




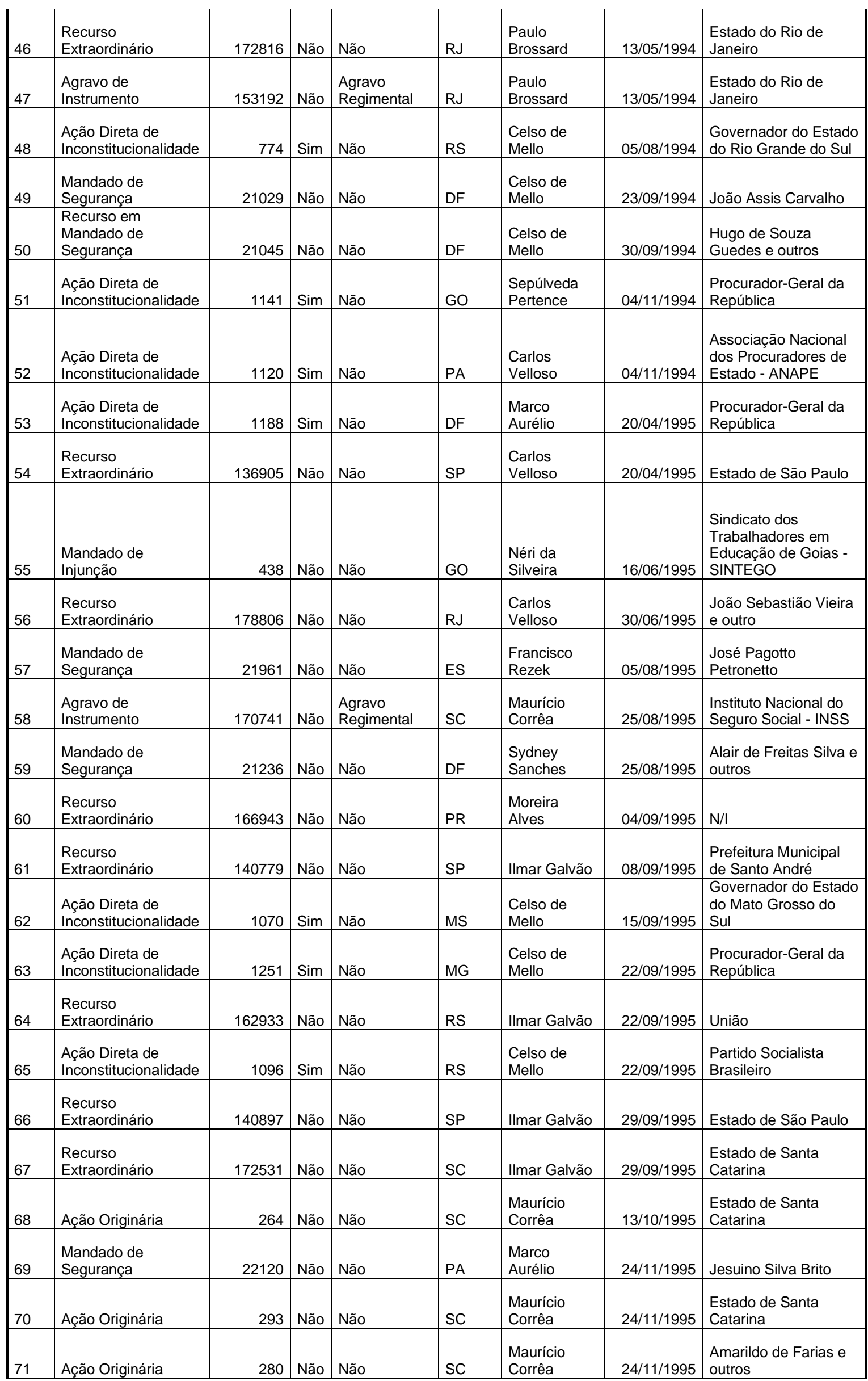




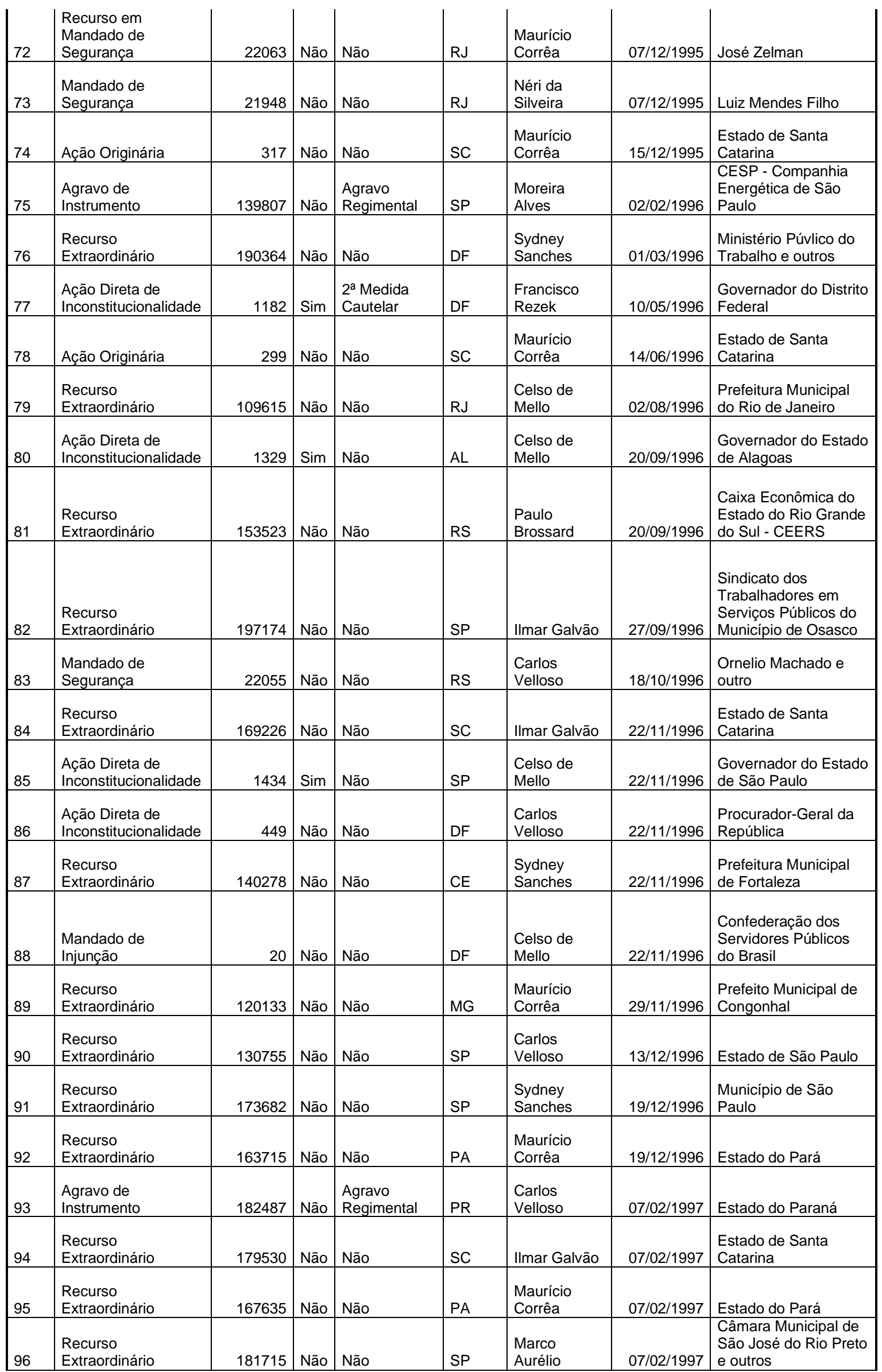




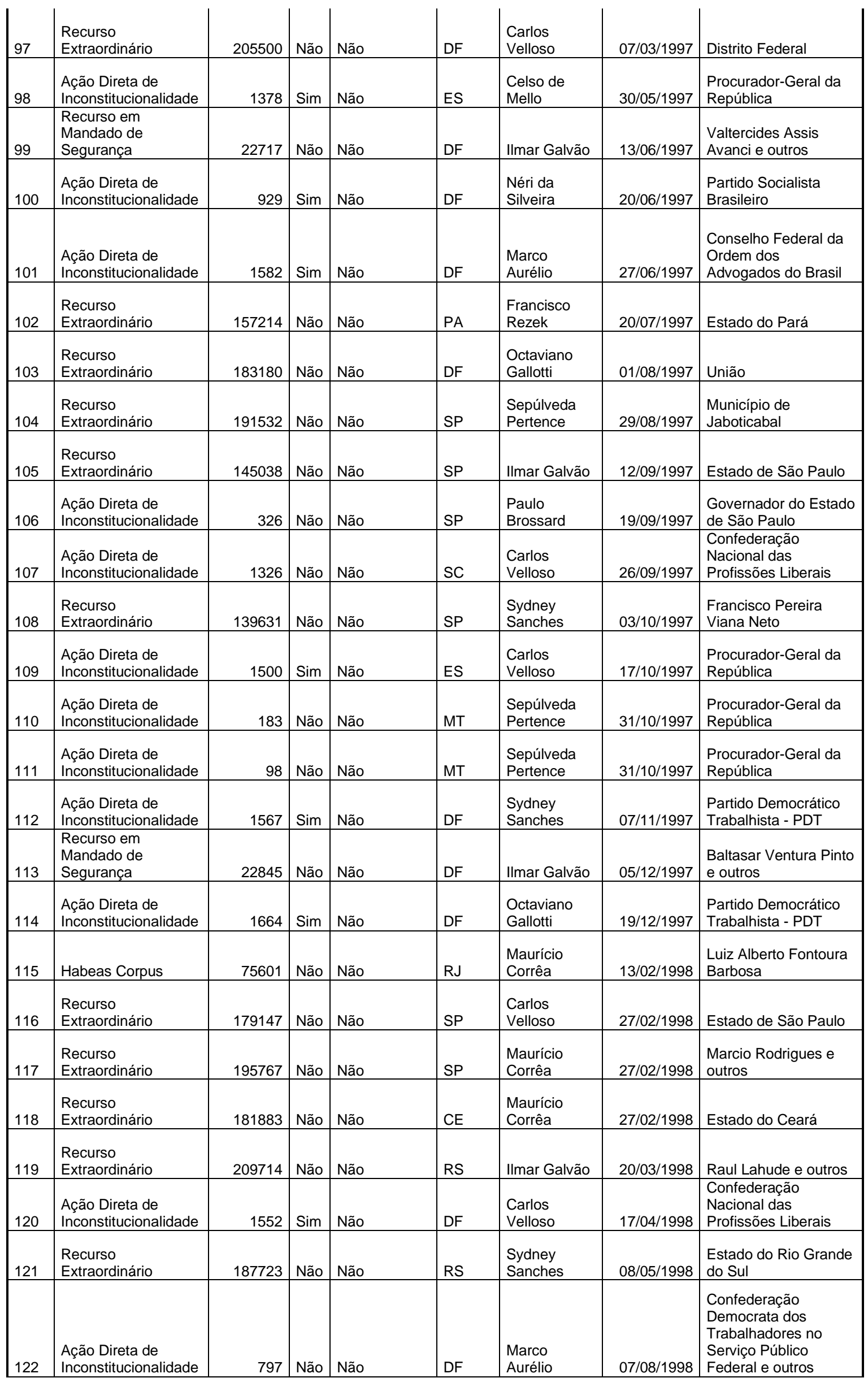




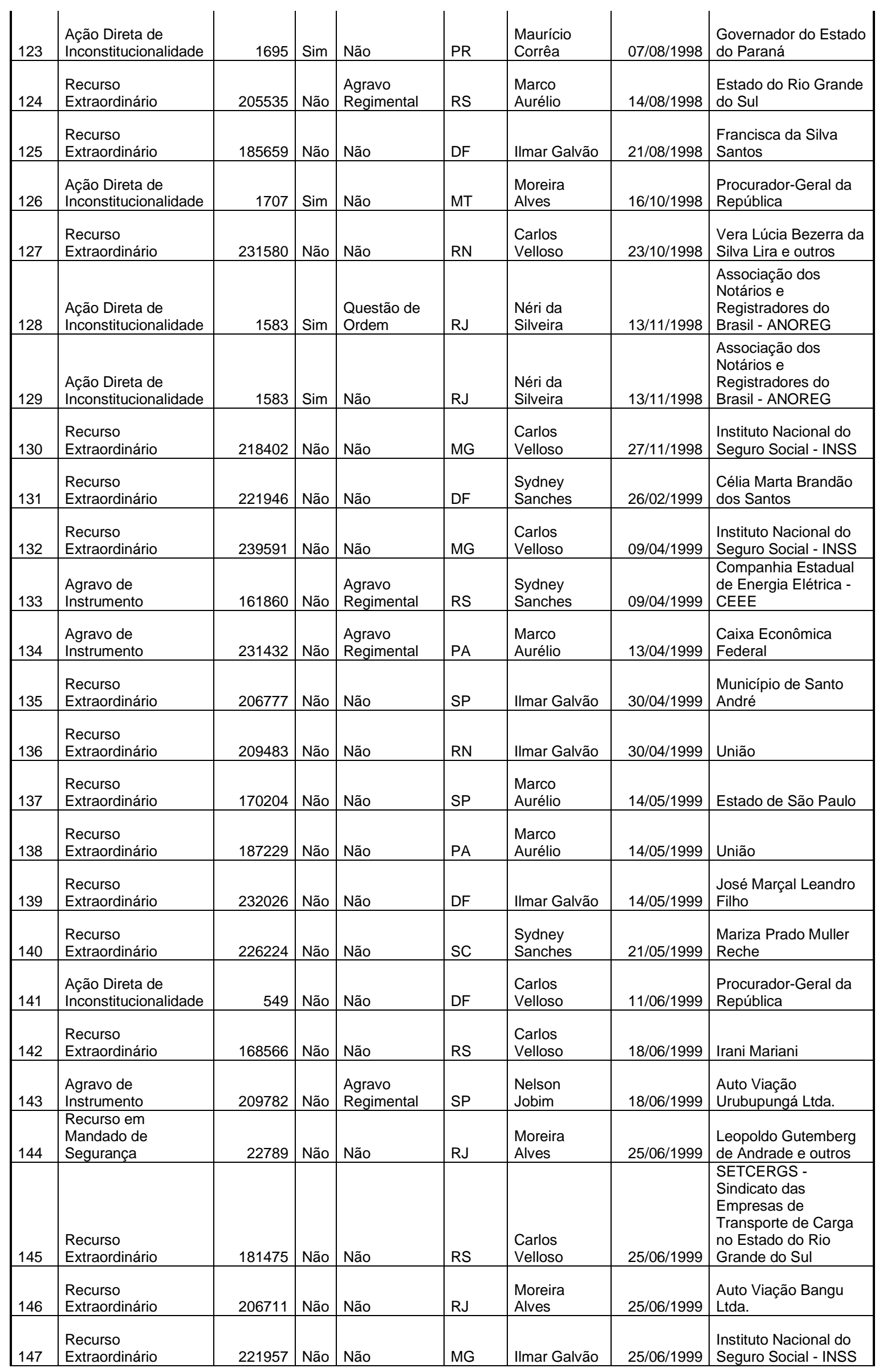




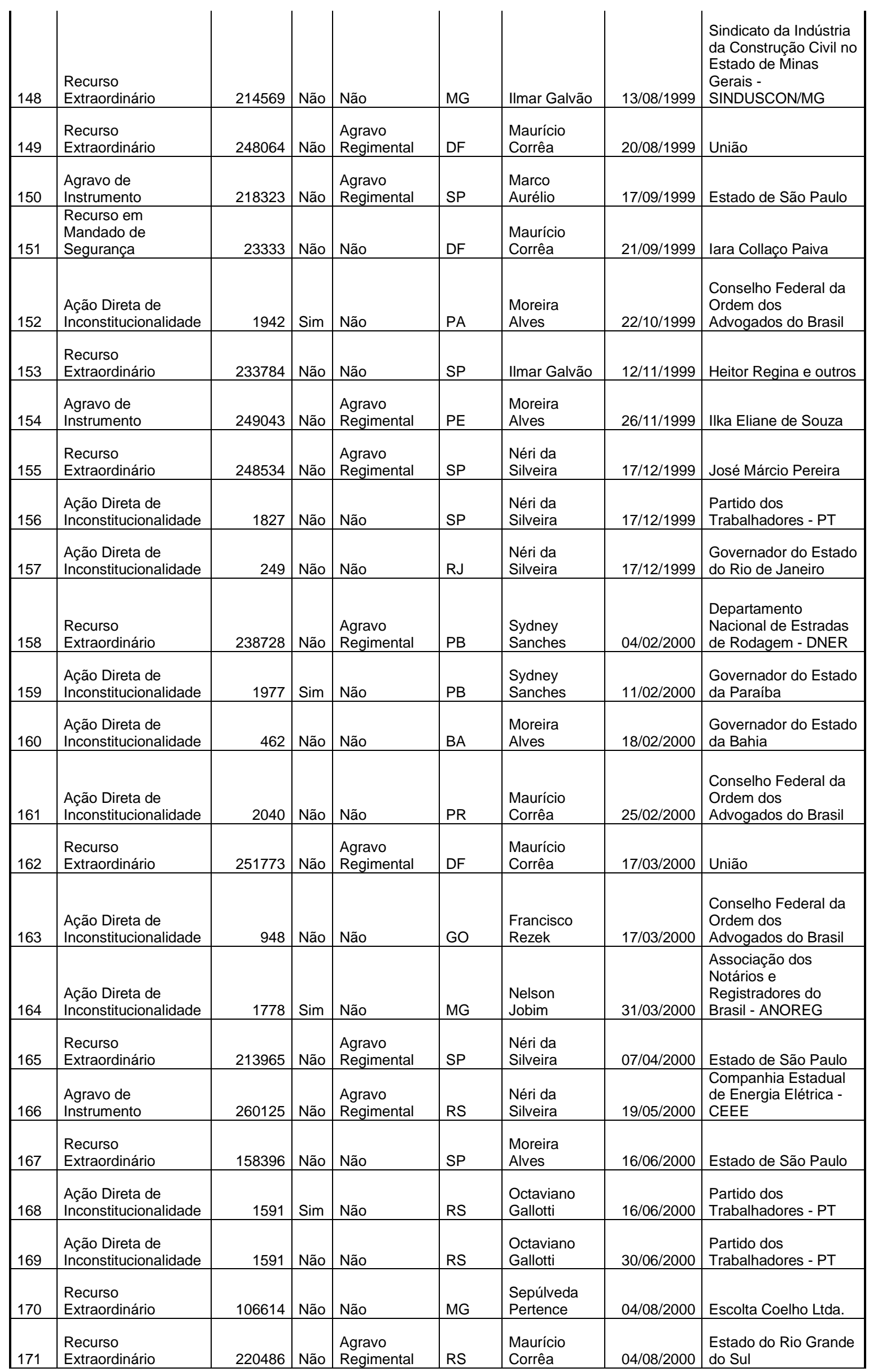




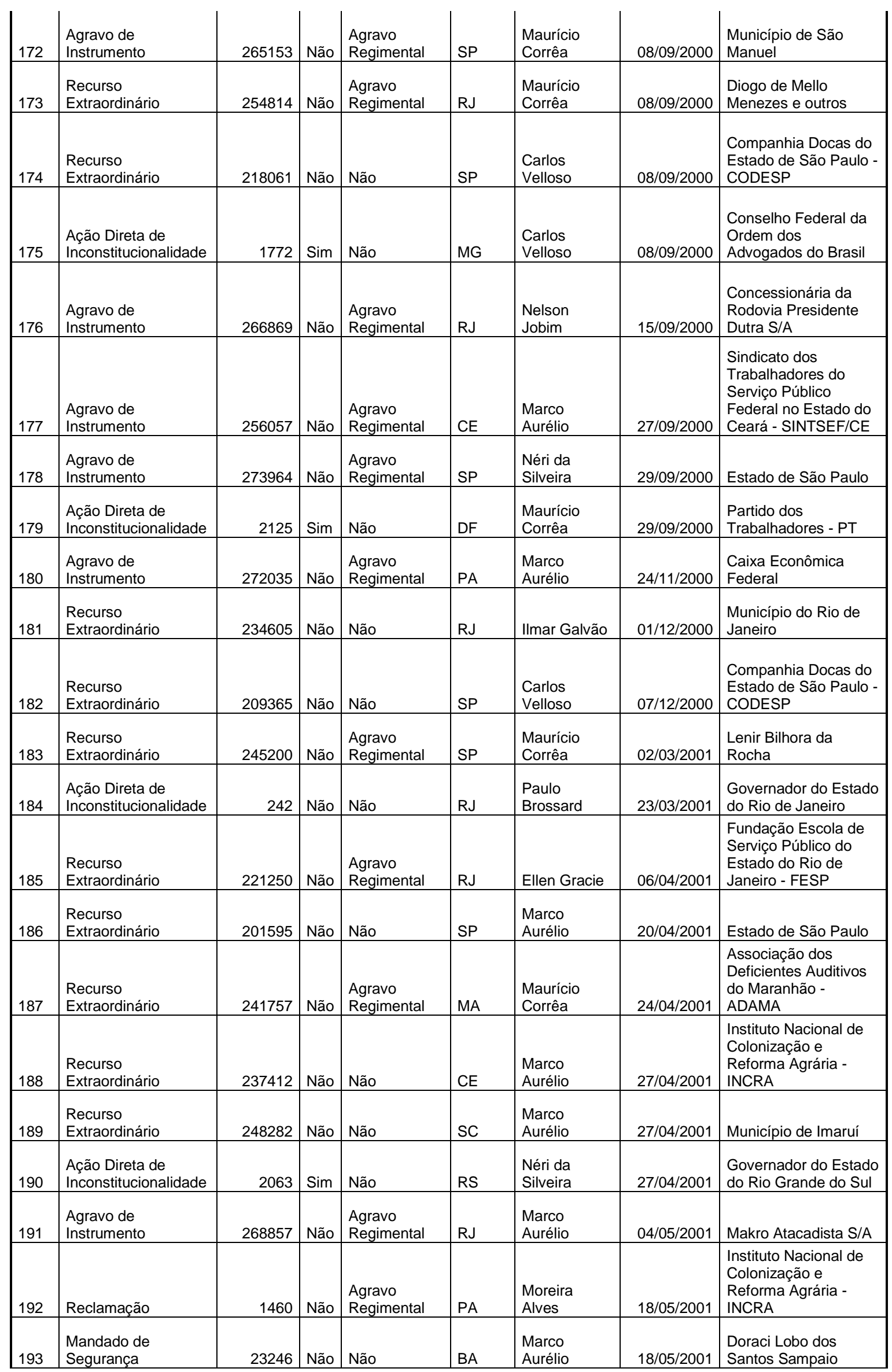




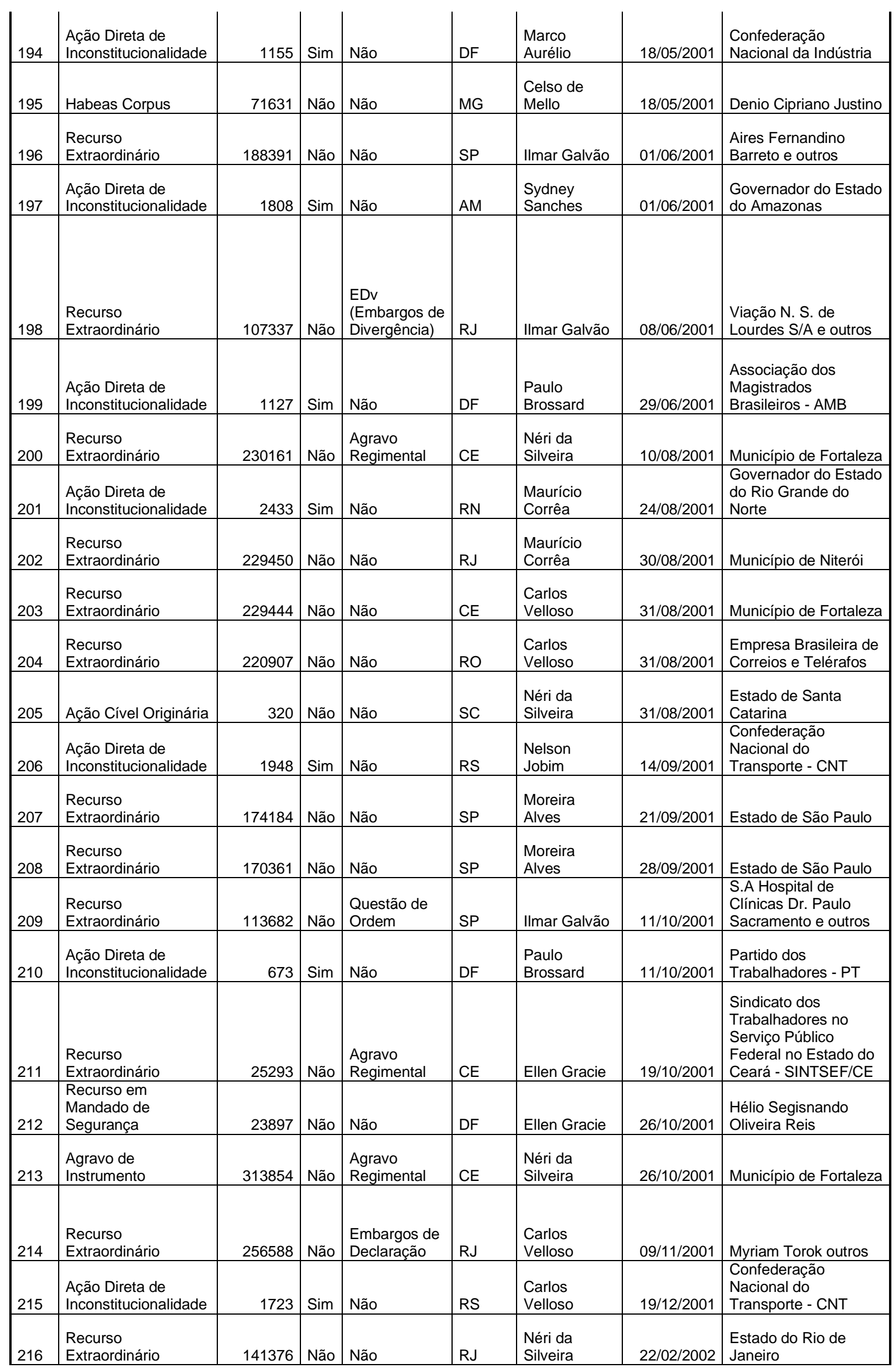




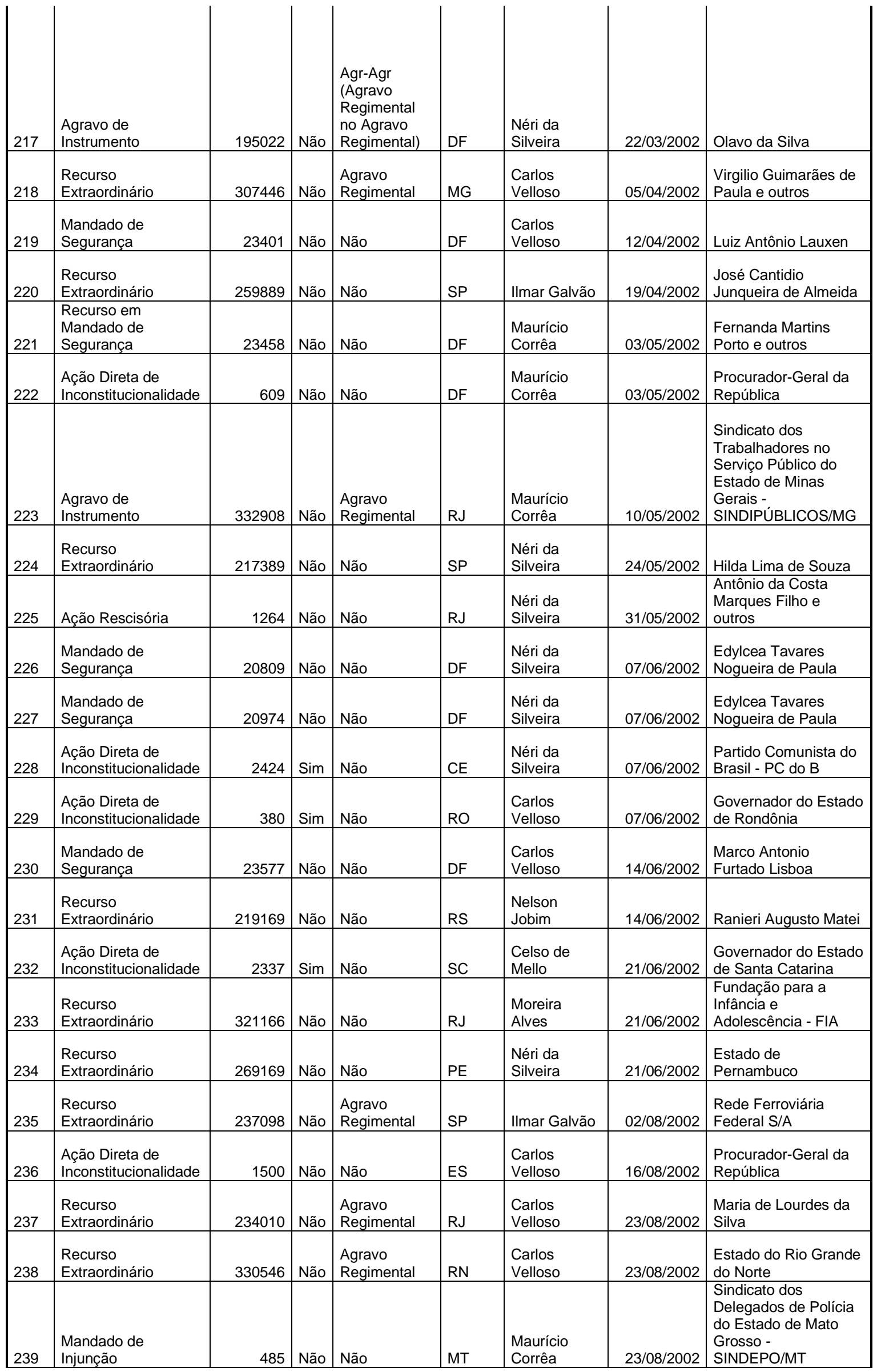




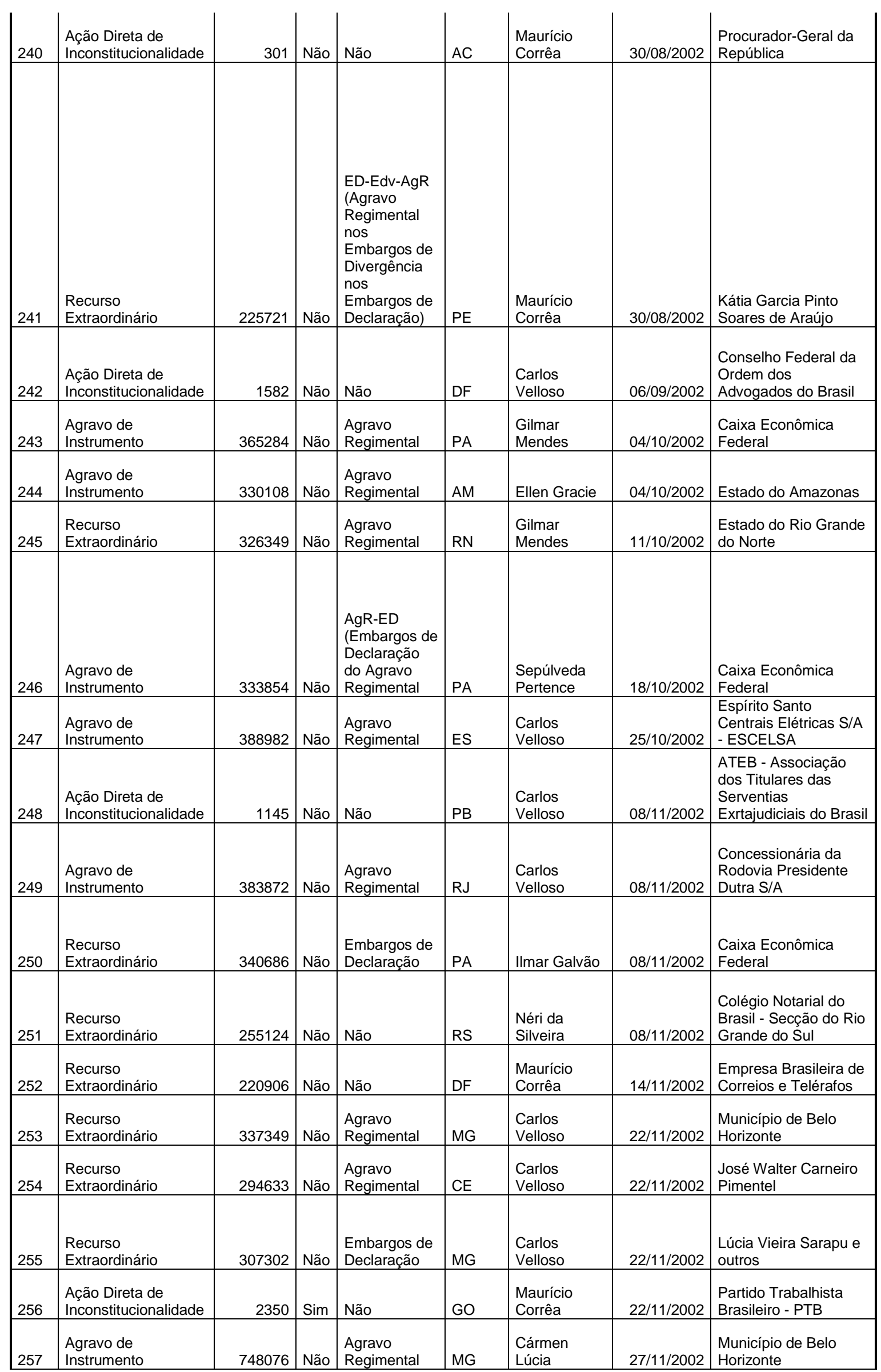




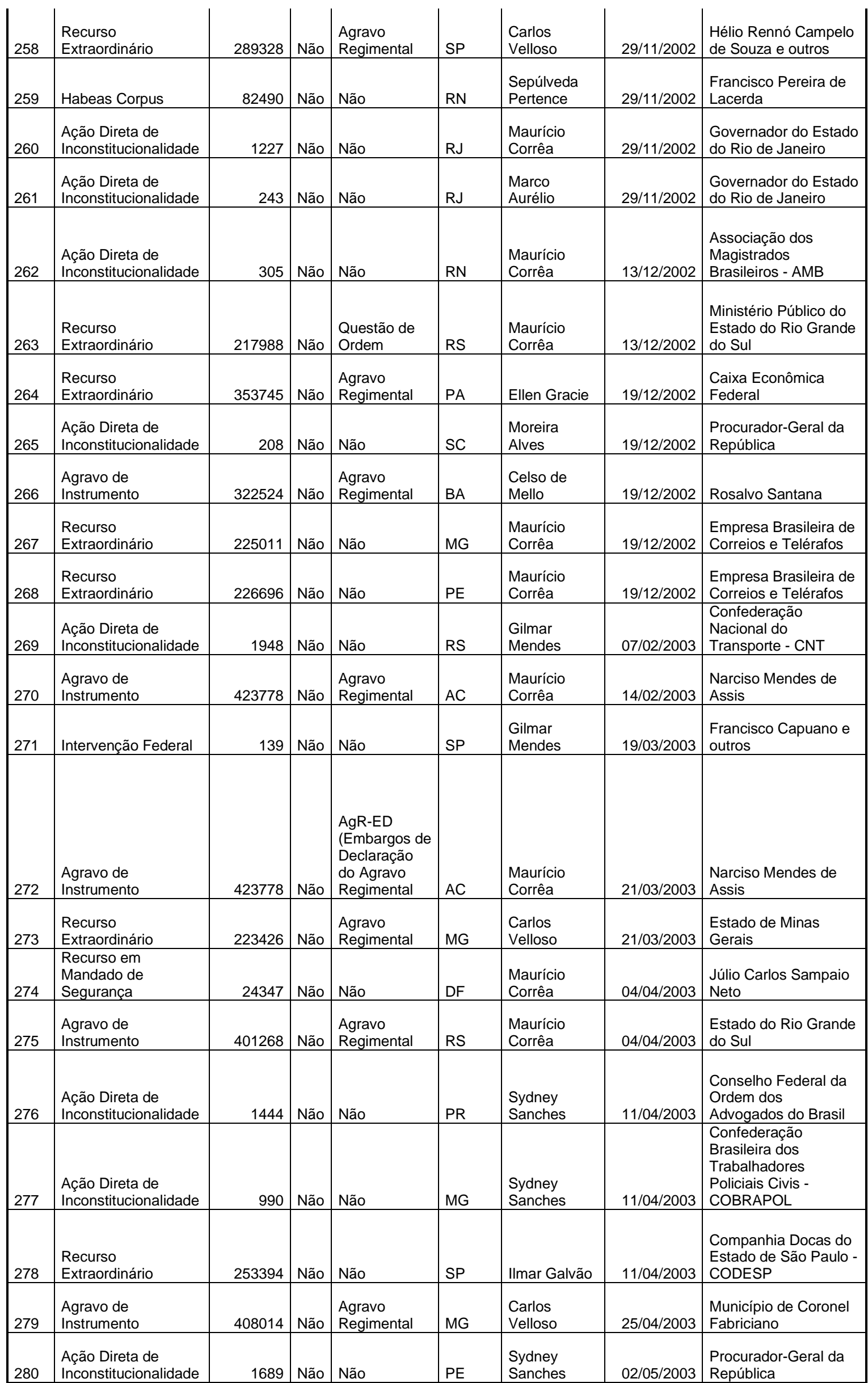




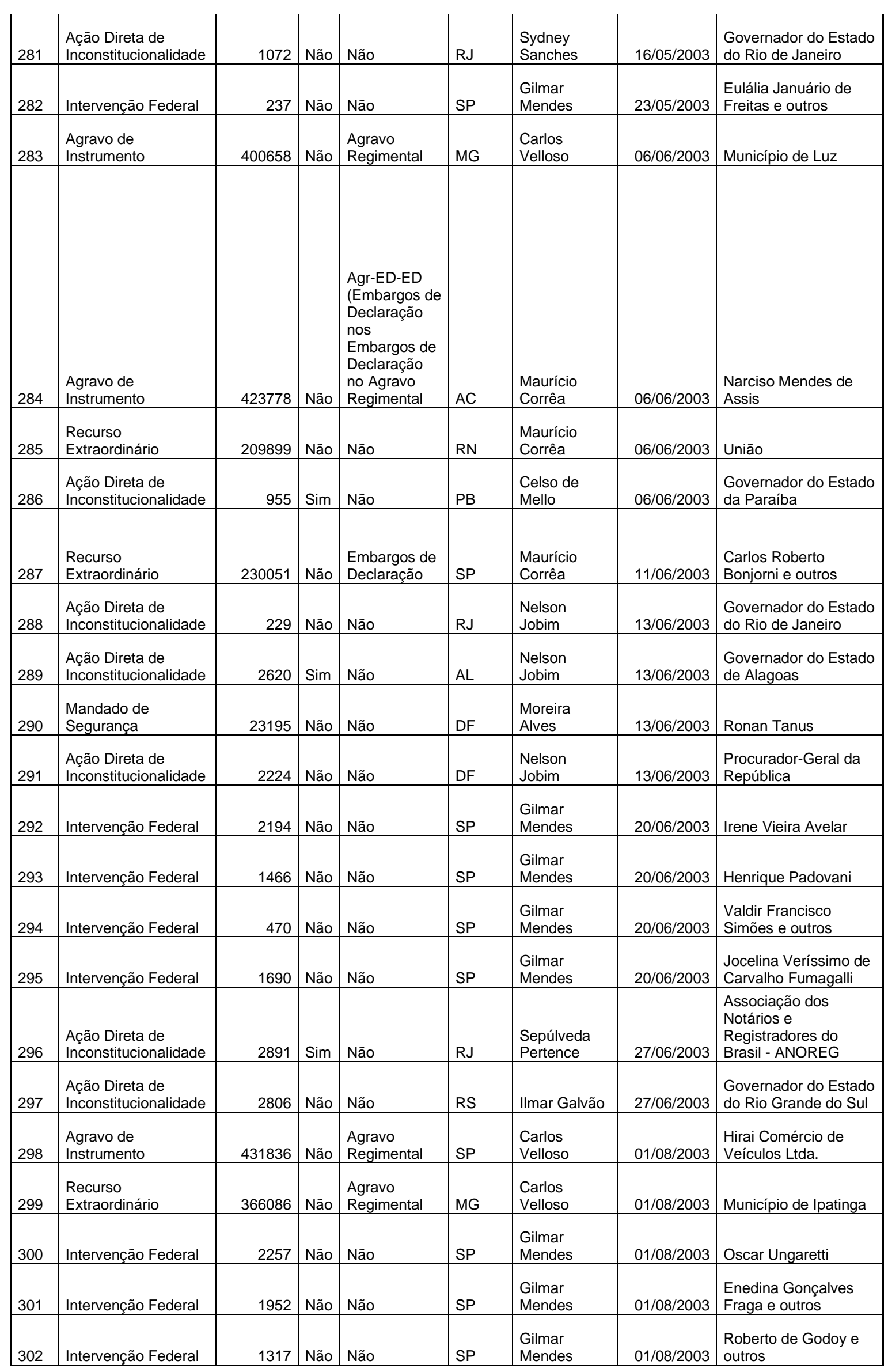




\begin{tabular}{|c|c|c|c|c|c|c|c|c|}
\hline 303 & Intervenção Federal & 492 & Não & Não & $\mathrm{SP}$ & \begin{tabular}{|l} 
Gilmar \\
Mendes
\end{tabular} & $01 / 08 / 2003$ & $\begin{array}{l}\text { Madalena Jacobs e } \\
\text { outros }\end{array}$ \\
\hline 304 & Intervenção Federal & 171 & Não & Não & SP & $\begin{array}{l}\text { Gilmar } \\
\text { Mendes }\end{array}$ & $01 / 08 / 2003$ & Rodolfo Melardi \\
\hline 305 & Intervenção Federal & 317 & Não & Não & SP & $\begin{array}{l}\text { Gilmar } \\
\text { Mendes }\end{array}$ & $01 / 08 / 2003$ & $\begin{array}{l}\text { Sanita Guedes e } \\
\text { outros }\end{array}$ \\
\hline 306 & $\begin{array}{l}\text { Ação Direta de } \\
\text { Inconstitucionalidade }\end{array}$ & 2586 & Não & Não & DF & \begin{tabular}{|l} 
Carlos \\
Velloso \\
\end{tabular} & $01 / 08 / 2003$ & $\begin{array}{l}\text { Confederação } \\
\text { Nacional da Indústria }\end{array}$ \\
\hline 307 & Intervenção Federal & 3601 & Não & Não & SP & \begin{tabular}{|l} 
Gilmar \\
Mendes
\end{tabular} & $22 / 08 / 2003$ & $\begin{array}{l}\text { Sérgio Moretto e } \\
\text { outros }\end{array}$ \\
\hline 308 & Intervenção Federal & 3046 & Não & Não & SP & $\begin{array}{l}\text { Gilmar } \\
\text { Mendes }\end{array}$ & $22 / 08 / 2003$ & Carlos Torrecilhas \\
\hline 309 & Intervenção Federal & 2909 & Não & Não & SP & $\begin{array}{l}\text { Gilmar } \\
\text { Mendes }\end{array}$ & $22 / 08 / 2003$ & $\begin{array}{l}\text { Rachel Paes Casarini } \\
\text { e outros }\end{array}$ \\
\hline 310 & Intervenção Federal & 2737 & Não & Não & SP & \begin{tabular}{|l} 
Gilmar \\
Mendes
\end{tabular} & $22 / 08 / 2003$ & $\begin{array}{l}\text { Máximo Antônio } \\
\text { Pontes e outros }\end{array}$ \\
\hline 311 & Intervenção Federal & 2805 & Não & Não & SP & $\begin{array}{l}\text { Gilmar } \\
\text { Mendes }\end{array}$ & $22 / 08 / 2003$ & Fausto Nogueira \\
\hline 312 & Intervenção Federal & 2127 & Não & Não & SP & $\begin{array}{l}\text { Gilmar } \\
\text { Mendes }\end{array}$ & $22 / 08 / 2003$ & Ivam Ferreira e outros \\
\hline 313 & Intervenção Federal & 2975 & Não & Não & SP & \begin{tabular}{|l} 
Gilmar \\
Mendes \\
\end{tabular} & $22 / 08 / 2003$ & \begin{tabular}{|l} 
Clovis Augusto \\
Machado e outros \\
\end{tabular} \\
\hline 314 & Intervenção Federal & 3578 & Não & Não & SP & \begin{tabular}{|l} 
Gilmar \\
Mendes
\end{tabular} & $22 / 08 / 2003$ & $\begin{array}{l}\text { Onizia Paulina da } \\
\text { Silva e outros }\end{array}$ \\
\hline 315 & Reclamação & 1870 & Não & Não & RS & $\begin{array}{l}\text { Gilmar } \\
\text { Mendes }\end{array}$ & $22 / 08 / 2003$ & $\begin{array}{l}\text { Município de Campo } \\
\text { Bom }\end{array}$ \\
\hline 316 & Intervenção Federal & 2973 & Não & Não & SP & \begin{tabular}{|l} 
Gilmar \\
Mendes
\end{tabular} & $29 / 08 / 2003$ & $\begin{array}{l}\text { Terezinha Cardoso e } \\
\text { outros }\end{array}$ \\
\hline 317 & Intervenção Federal & 3292 & Não & Não & SP & $\begin{array}{l}\text { Gilmar } \\
\text { Mendes }\end{array}$ & $29 / 08 / 2003$ & Marinez viol e outros \\
\hline 318 & Intervenção Federal & 449 & Não & Não & SP & $\begin{array}{l}\text { Gilmar } \\
\text { Mendes }\end{array}$ & $29 / 08 / 2003$ & $\begin{array}{l}\text { Joseline Florenzano } \\
\text { Vidal Gonçalves e } \\
\text { outros }\end{array}$ \\
\hline 319 & Habeas Corpus & 80751 & Não & Não & $\mathrm{RS}$ & \begin{tabular}{|l|}
$\begin{array}{l}\text { Nelson } \\
\text { Jobim }\end{array}$ \\
\end{tabular} & $29 / 08 / 2003$ & $\begin{array}{l}\text { Amilcar Baruc Rizzo } \\
\text { Corrêa }\end{array}$ \\
\hline 320 & $\begin{array}{l}\text { Ação Direta de } \\
\text { Inconstitucionalidade }\end{array}$ & 2299 & Sim & Não & $\mathrm{RS}$ & $\begin{array}{l}\text { Moreira } \\
\text { Alves }\end{array}$ & $29 / 08 / 2003$ & $\begin{array}{l}\text { Governador do Estado } \\
\text { do Rio Grande do Sul }\end{array}$ \\
\hline 321 & $\begin{array}{l}\text { Ação Direta de } \\
\text { Inconstitucionalidade }\end{array}$ & 2340 & Sim & Não & SC & $\begin{array}{l}\text { Marco } \\
\text { Aurélio } \\
\end{array}$ & $29 / 08 / 2003$ & $\begin{array}{l}\text { Governador do Estado } \\
\text { de Santa Catarina }\end{array}$ \\
\hline 322 & $\begin{array}{l}\text { Recurso } \\
\text { Extraordinário }\end{array}$ & 383405 & Não & \begin{tabular}{|l} 
Agravo \\
Regimental \\
\end{tabular} & $\mathrm{SC}$ & Ellen Gracie & $12 / 09 / 2003$ & Jaci Jurandir Favretto \\
\hline 323 & $\begin{array}{l}\text { Ação Direta de } \\
\text { Inconstitucionalidade }\end{array}$ & 2095 & Sim & Não & RS & $\begin{array}{l}\text { Octaviano } \\
\text { Gallotti }\end{array}$ & $19 / 09 / 2003$ & $\begin{array}{l}\text { Governador do Estado } \\
\text { do Rio Grande do Sul }\end{array}$ \\
\hline 324 & $\begin{array}{l}\text { Ação Declaratória de } \\
\text { Constitucionalidade }\end{array}$ & 5 & Sim & Não & DF & $\begin{array}{l}\text { Nelson } \\
\text { Jobim }\end{array}$ & $19 / 09 / 2003$ & $\begin{array}{l}\text { Procurador-Geral da } \\
\text { República }\end{array}$ \\
\hline 325 & $\begin{array}{l}\text { Ação Direta de } \\
\text { Inconstitucionalidade }\end{array}$ & 1746 & Sim & Não & SP & $\begin{array}{l}\text { Maurício } \\
\text { Corrêa }\end{array}$ & $19 / 09 / 2003$ & $\begin{array}{l}\text { Governador do Estado } \\
\text { de São Paulo }\end{array}$ \\
\hline 326 & $\begin{array}{l}\text { Ação Direta de } \\
\text { Inconstitucionalidade }\end{array}$ & 2254 & Sim & Não & ES & $\begin{array}{l}\text { Sepúlveda } \\
\text { Pertence }\end{array}$ & $26 / 09 / 2003$ & $\begin{array}{l}\text { Governador do Estado } \\
\text { do Espírito Santo }\end{array}$ \\
\hline 327 & $\begin{array}{l}\text { Recurso } \\
\text { Extraordinário }\end{array}$ & 256588 & Não & $\begin{array}{l}\text { ED-Edv } \\
\text { (Embargos de } \\
\text { Divergência } \\
\text { nos } \\
\text { Embargos de } \\
\text { Declaração) }\end{array}$ & RJ & Ellen Gracie & 03/10/2003 & Myriam Torok outros \\
\hline
\end{tabular}




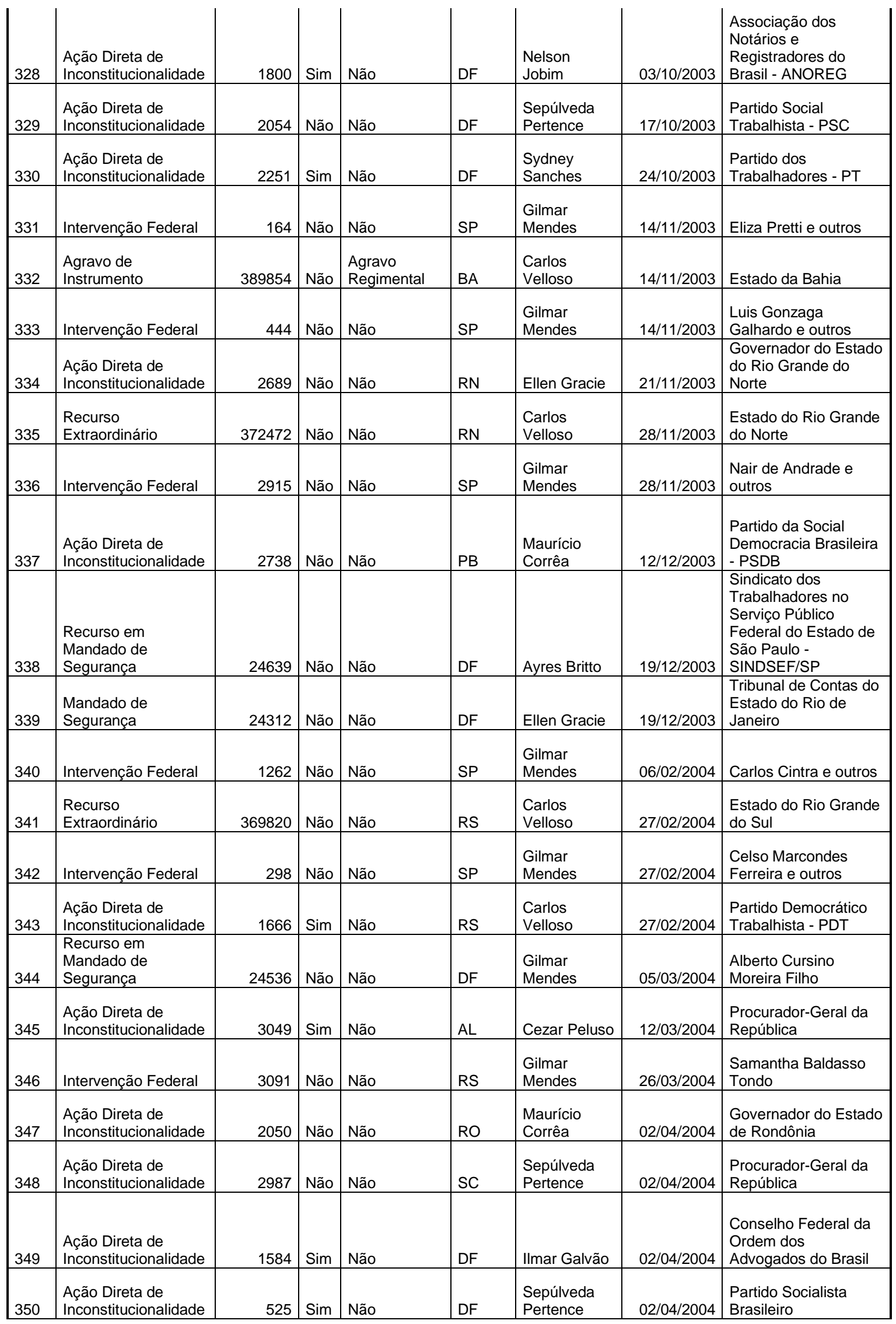




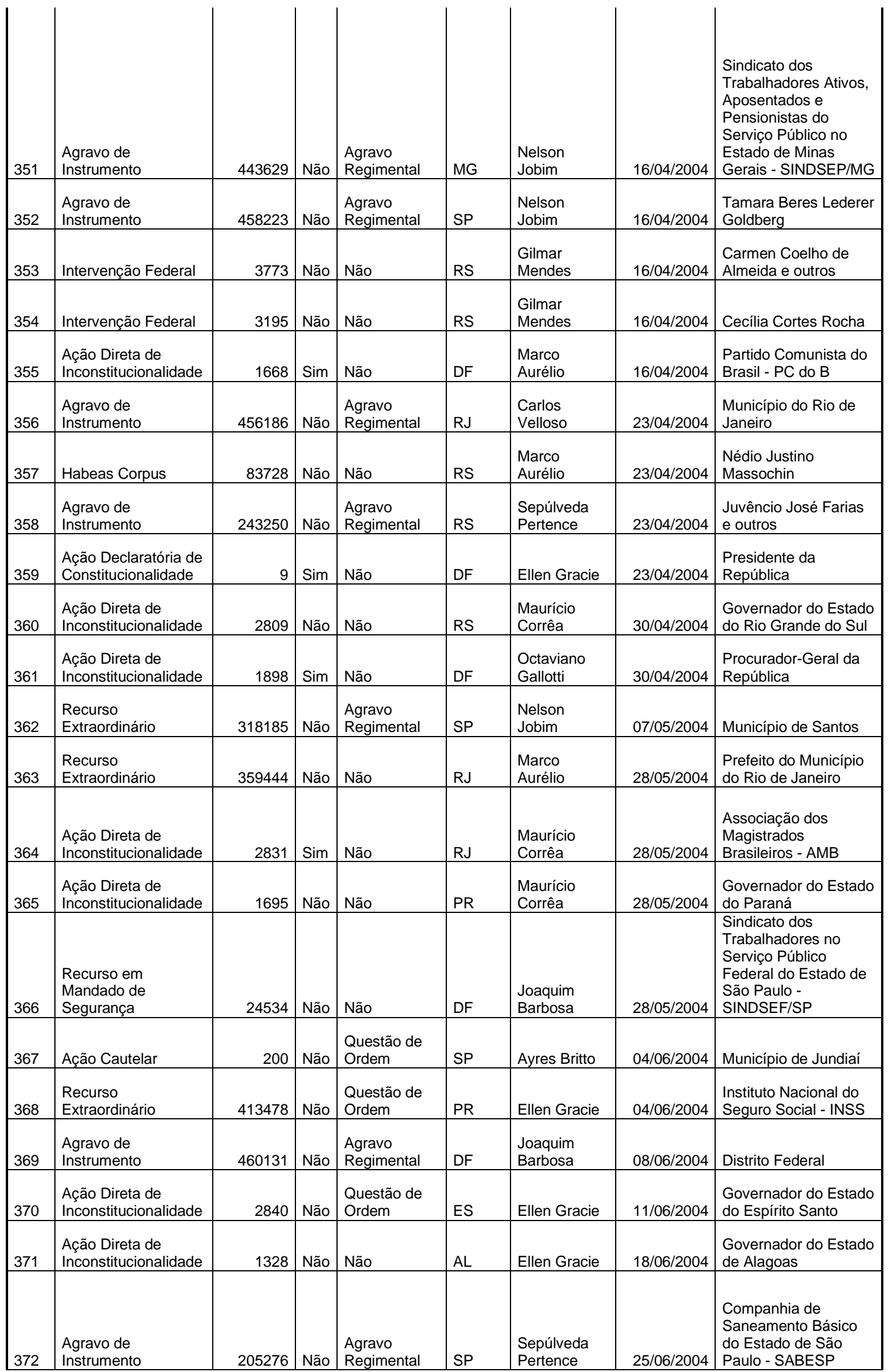




\begin{tabular}{|c|c|c|c|c|c|c|c|c|}
\hline 373 & $\begin{array}{l}\text { Recurso } \\
\text { Extraordinário }\end{array}$ & 407099 & Não & Não & RS & $\begin{array}{l}\text { Carlos } \\
\text { Velloso }\end{array}$ & $06 / 08 / 2004$ & $\begin{array}{l}\text { Empresa Brasileira de } \\
\text { Correios e Telérafos }\end{array}$ \\
\hline 374 & $\begin{array}{l}\text { Recurso em } \\
\text { Mandado de } \\
\text { Segurança }\end{array}$ & 24726 & Não & Não & DF & $\begin{array}{l}\text { Marco } \\
\text { Aurélio }\end{array}$ & 06/08/2004 & \begin{tabular}{|l|} 
Sindicato dos \\
Trabalhadores no \\
Serviço Público \\
Federal do Estado de \\
São Paulo - \\
SINDSEF/SP \\
\end{tabular} \\
\hline 375 & $\begin{array}{l}\text { Ação Direta de } \\
\text { Inconstitucionalidade }\end{array}$ & 3080 & Não & Não & $\mathrm{SC}$ & Ellen Gracie & $27 / 08 / 2004$ & $\begin{array}{l}\text { Procurador-Geral da } \\
\text { República }\end{array}$ \\
\hline 376 & $\begin{array}{l}\text { Recurso } \\
\text { Extraordinário }\end{array}$ & 354897 & Não & Não & RS & $\begin{array}{l}\text { Carlos } \\
\text { Velloso }\end{array}$ & 03/09/2004 & $\begin{array}{l}\text { Empresa Brasileira de } \\
\text { Correios e Telérafos }\end{array}$ \\
\hline 377 & $\begin{array}{l}\text { Recurso em } \\
\text { Mandado de } \\
\text { Segurança }\end{array}$ & 24737 & Não & Não & DF & Ayres Britto & 03/09/2004 & $\begin{array}{l}\text { Maria Luiza Tavares } \\
\text { Benício }\end{array}$ \\
\hline 378 & $\begin{array}{l}\text { Recurso } \\
\text { Extraordinário }\end{array}$ & 424227 & Não & Não & SC & $\begin{array}{l}\text { Carlos } \\
\text { Velloso } \\
\end{array}$ & 10/09/2004 & $\begin{array}{l}\text { Empresa Brasileira de } \\
\text { Correios e Telérafos } \\
\end{array}$ \\
\hline 379 & $\begin{array}{l}\text { Recurso } \\
\text { Extraordinário }\end{array}$ & 398630 & Não & Não & SP & $\begin{array}{l}\text { Carlos } \\
\text { Velloso }\end{array}$ & $17 / 09 / 2004$ & $\begin{array}{l}\text { Empresa Brasileira de } \\
\text { Correios e Telérafos }\end{array}$ \\
\hline 380 & $\begin{array}{l}\text { Ação Direta de } \\
\text { Inconstitucionalidade }\end{array}$ & 100 & Não & Não & MG & Ellen Gracie & 01/10/2004 & $\begin{array}{l}\text { Governador do Estado } \\
\text { de Minas Gerais }\end{array}$ \\
\hline 381 & $\begin{array}{l}\text { Recurso } \\
\text { Extraordinário }\end{array}$ & 382054 & Não & Não & RJ & $\begin{array}{l}\text { Carlos } \\
\text { Velloso }\end{array}$ & 01/10/2004 & Jorge Luiz dos Santos \\
\hline 382 & $\begin{array}{l}\text { Agravo de } \\
\text { Instrumento }\end{array}$ & 458269 & Não & $\begin{array}{l}\text { Agravo } \\
\text { Regimental }\end{array}$ & DF & $\begin{array}{l}\text { Carlos } \\
\text { Velloso } \\
\end{array}$ & $22 / 10 / 2004$ & União \\
\hline 383 & $\begin{array}{l}\text { Recurso } \\
\text { Extraordinário }\end{array}$ & 364202 & Não & Não & RS & $\begin{array}{l}\text { Carlos } \\
\text { Velloso }\end{array}$ & 28/10/2004 & $\begin{array}{l}\text { Empresa Brasileira de } \\
\text { Correios e Telérafos }\end{array}$ \\
\hline 384 & $\begin{array}{l}\text { Ação Direta de } \\
\text { Inconstitucionalidade }\end{array}$ & 1905 & Sim & Não & RS & $\begin{array}{l}\text { Sepúlveda } \\
\text { Pertence }\end{array}$ & 05/11/2004 & $\begin{array}{l}\text { Associação dos } \\
\text { Magistrados } \\
\text { Brasileiros - AMB }\end{array}$ \\
\hline 385 & $\begin{array}{l}\text { Recurso em } \\
\text { Mandado de } \\
\text { Segurança } \\
\end{array}$ & 24836 & Não & Não & DF & $\begin{array}{l}\text { Carlos } \\
\text { Velloso }\end{array}$ & 09/11/2004 & \begin{tabular}{|l|} 
Sindicato dos \\
Trabalhadores no \\
Serviço Público \\
Federal do Estado de \\
São Paulo - \\
SINDSEF/SP \\
\end{tabular} \\
\hline 386 & $\begin{array}{l}\text { Agravo de } \\
\text { Instrumento }\end{array}$ & 465746 & Não & $\begin{array}{l}\text { Agravo } \\
\text { Regimental }\end{array}$ & $\mathrm{RS}$ & Eros Grau & $26 / 11 / 2004$ & $\begin{array}{l}\text { Roseli Maria Feix } \\
\text { Tusset }\end{array}$ \\
\hline 387 & $\begin{array}{l}\text { Ação Direta de } \\
\text { Inconstitucionalidade }\end{array}$ & 2847 & Não & Não & DF & $\begin{array}{l}\text { Carlos } \\
\text { Velloso }\end{array}$ & $26 / 11 / 2004$ & $\begin{array}{l}\text { Procurador-Geral da } \\
\text { República }\end{array}$ \\
\hline 388 & $\begin{array}{l}\text { Agravo de } \\
\text { Instrumento }\end{array}$ & 495967 & Não & $\begin{array}{l}\text { Agravo } \\
\text { Regimental }\end{array}$ & SP & $\begin{array}{l}\text { Carlos } \\
\text { Velloso }\end{array}$ & 03/12/2004 & Paulo Drefahl \\
\hline 389 & $\begin{array}{l}\text { Recurso } \\
\text { Extraordinário } \\
\end{array}$ & 422830 & Não & $\begin{array}{l}\text { Agravo } \\
\text { Regimental }\end{array}$ & SC & $\begin{array}{l}\text { Carlos } \\
\text { Velloso }\end{array}$ & $10 / 12 / 2004$ & $\begin{array}{l}\text { Estado de Santa } \\
\text { Catarina }\end{array}$ \\
\hline 390 & $\begin{array}{l}\text { Agravo de } \\
\text { Instrumento }\end{array}$ & 514815 & Não & $\begin{array}{l}\text { Agravo } \\
\text { Regimental }\end{array}$ & DF & $\begin{array}{l}\text { Carlos } \\
\text { Velloso }\end{array}$ & $17 / 12 / 2004$ & Distrito Federal \\
\hline 391 & \begin{tabular}{|l|} 
Recurso em \\
Mandado de \\
Segurança \\
\end{tabular} & 24901 & Não & Não & DF & $\begin{array}{l}\text { Carlos } \\
\text { Velloso }\end{array}$ & $11 / 02 / 2005$ & $\begin{array}{l}\text { Ministério Público } \\
\text { Federal }\end{array}$ \\
\hline 392 & \begin{tabular}{|l|} 
Recurso \\
Extraordinário \\
\end{tabular} & 302803 & Não & Não & RJ & Ellen Gracie & $25 / 02 / 2005$ & $\begin{array}{l}\text { Câmara Municipal do } \\
\text { Rio de Janeiro }\end{array}$ \\
\hline 393 & $\begin{array}{l}\text { Agravo de } \\
\text { Instrumento }\end{array}$ & 392684 & Não & $\begin{array}{l}\text { Agravo } \\
\text { Regimental }\end{array}$ & $\mathrm{BA}$ & $\begin{array}{l}\text { Sepúlveda } \\
\text { Pertence }\end{array}$ & $01 / 03 / 2005$ & Estado da Bahia \\
\hline 394 & \begin{tabular}{|l|} 
Recurso \\
Extraordinário \\
\end{tabular} & 286107 & Não & $\begin{array}{l}\text { Agravo } \\
\text { Regimental }\end{array}$ & SP & Ellen Gracie & 04/03/2005 & $\begin{array}{l}\text { Marialice Tessari de } \\
\text { Matos }\end{array}$ \\
\hline 395 & $\begin{array}{l}\text { Recurso } \\
\text { Extraordinário }\end{array}$ & 333244 & Não & $\begin{array}{l}\text { Agravo } \\
\text { Regimental }\end{array}$ & SC & Cezar Peluso & 04/03/2005 & $\begin{array}{l}\text { Instituto Nacional do } \\
\text { Seguro Social - INSS }\end{array}$ \\
\hline 396 & $\begin{array}{l}\text { Agravo de } \\
\text { Instrumento }\end{array}$ & 390986 & Não & $\begin{array}{l}\text { Agravo } \\
\text { Regimental }\end{array}$ & $\mathrm{BA}$ & $\begin{array}{l}\text { Sepúlveda } \\
\text { Pertence }\end{array}$ & $11 / 03 / 2005$ & Estado da Bahia \\
\hline 397 & $\begin{array}{l}\text { Mandado de } \\
\text { Segurança }\end{array}$ & 24742 & Não & Não & DF & $\begin{array}{l}\text { Marco } \\
\text { Aurélio }\end{array}$ & $11 / 03 / 2005$ & Sonia Irsai Azevedo \\
\hline
\end{tabular}




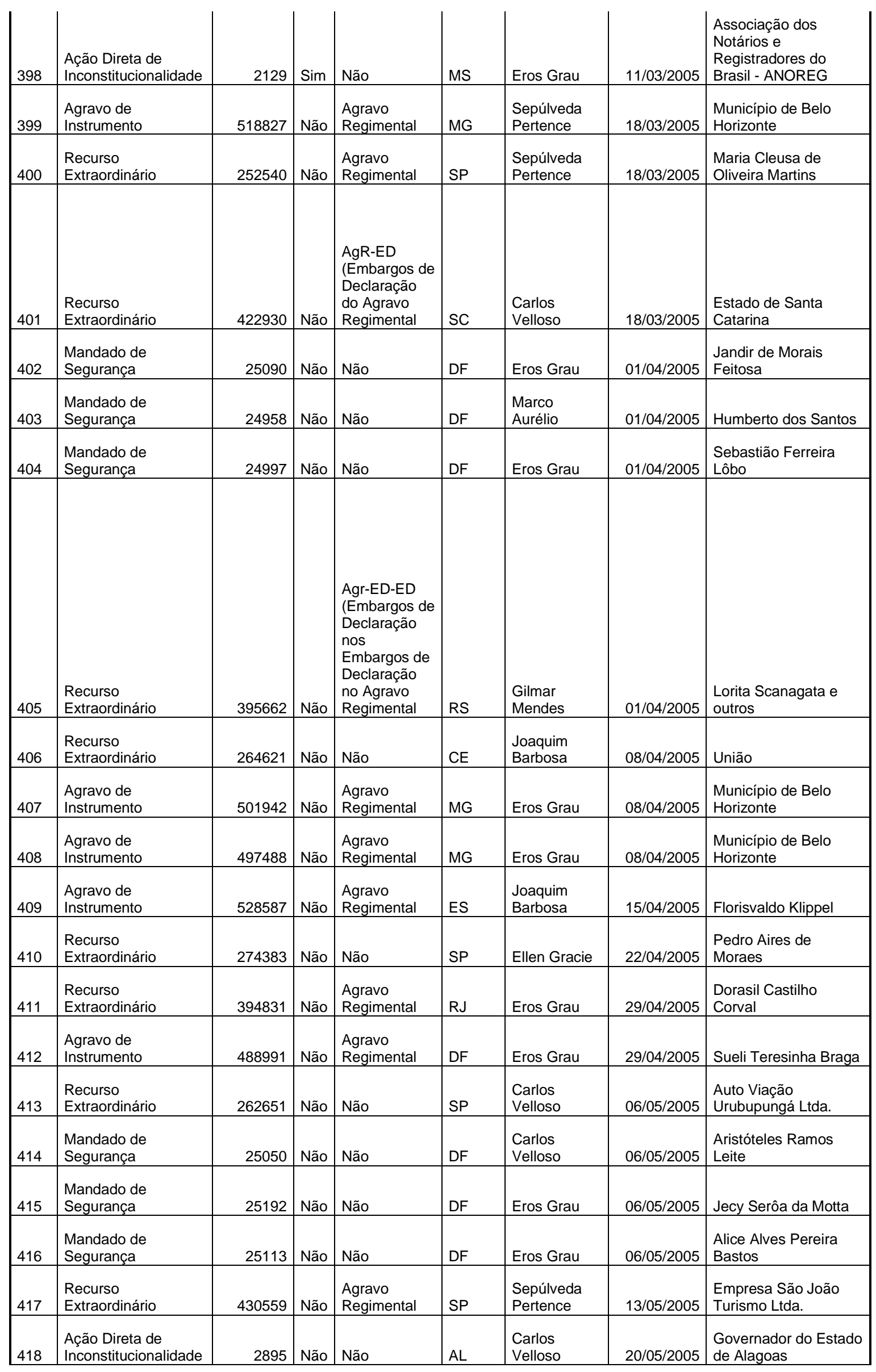




\begin{tabular}{|c|c|c|c|c|c|c|c|c|}
\hline 419 & Reclamação & 1017 & Não & Não & $\mathrm{SP}$ & \begin{tabular}{|l} 
Sepúlveda \\
Pertence
\end{tabular} & $03 / 06 / 2005$ & $\begin{array}{l}\text { Procurador-Geral da } \\
\text { República }\end{array}$ \\
\hline 420 & $\begin{array}{l}\text { Agravo de } \\
\text { Instrumento }\end{array}$ & 240992 & Não & $\begin{array}{l}\text { Agravo } \\
\text { Regimental }\end{array}$ & SP & Cezar Peluso & $10 / 06 / 2005$ & $\begin{array}{l}\text { Esdracir Martins de } \\
\text { Mello }\end{array}$ \\
\hline 421 & $\begin{array}{l}\text { Agravo de } \\
\text { Instrumento }\end{array}$ & 478745 & Não & $\begin{array}{l}\text { Agravo } \\
\text { Regimental }\end{array}$ & MG & Cezar Peluso & $17 / 06 / 2005$ & $\begin{array}{l}\text { Sindicato dos } \\
\text { Trabalhadores Ativos, } \\
\text { Aposentados e } \\
\text { Pensionistas do } \\
\text { Serviço Público no } \\
\text { Estado de Minas } \\
\text { Gerais - SINDSEP/MG } \\
\end{array}$ \\
\hline 422 & $\begin{array}{l}\text { Agravo de } \\
\text { Instrumento }\end{array}$ & 491764 & Não & $\begin{array}{l}\text { Agravo } \\
\text { Regimental }\end{array}$ & MG & Cezar Peluso & $17 / 06 / 2005$ & $\begin{array}{l}\text { Estado de Minas } \\
\text { Gerais }\end{array}$ \\
\hline 423 & $\begin{array}{l}\text { Recurso } \\
\text { Extraordinário }\end{array}$ & 190326 & Não & $\begin{array}{l}\text { Agravo } \\
\text { Regimental }\end{array}$ & SP & Eros Grau & $24 / 06 / 2005$ & Estado de São Paulo \\
\hline 424 & $\begin{array}{l}\text { Agravo de } \\
\text { Instrumento }\end{array}$ & 505473 & Não & $\begin{array}{l}\text { Agravo } \\
\text { Regimental }\end{array}$ & RJ & $\begin{array}{l}\text { Joaquim } \\
\text { Barbosa }\end{array}$ & $24 / 06 / 2005$ & Maria da Graça Luz \\
\hline 425 & $\begin{array}{l}\text { Recurso } \\
\text { Extraordinário }\end{array}$ & 167636 & Não & $\begin{array}{l}\text { Agravo } \\
\text { Regimental }\end{array}$ & PA & Cezar Peluso & $01 / 07 / 2005$ & Emilio Hage Karam \\
\hline 426 & $\begin{array}{l}\text { Recurso em } \\
\text { Mandado de } \\
\text { Segurança } \\
\end{array}$ & 24128 & Não & Não & DF & $\begin{array}{l}\text { Sepúlveda } \\
\text { Pertence }\end{array}$ & $01 / 07 / 2005$ & $\begin{array}{l}\text { Ozéas das Neves do } \\
\text { Nascimento }\end{array}$ \\
\hline 427 & $\begin{array}{l}\text { Recurso } \\
\text { Extraordinário } \\
\end{array}$ & 435210 & Não & $\begin{array}{l}\text { Agravo } \\
\text { Regimental }\end{array}$ & $\mathrm{AL}$ & Ellen Gracie & 05/08/2005 & $\begin{array}{l}\text { Departamento } \\
\text { Nacional de Produção } \\
\text { Mineral - DNPM } \\
\end{array}$ \\
\hline 428 & $\begin{array}{l}\text { Agravo de } \\
\text { Instrumento }\end{array}$ & 529743 & Não & $\begin{array}{l}\text { Agravo } \\
\text { Regimental }\end{array}$ & $\mathrm{DF}$ & \begin{tabular}{|l|} 
Carlos \\
Velloso \\
\end{tabular} & $05 / 08 / 2005$ & $\begin{array}{l}\text { Taguatur - Taguatinga } \\
\text { Transportes e Turismo } \\
\text { Ltda. }\end{array}$ \\
\hline 429 & $\begin{array}{l}\text { Ação Direta de } \\
\text { Inconstitucionalidade }\end{array}$ & 396 & Não & Não & RS & $\begin{array}{l}\text { Gilmar } \\
\text { Mendes }\end{array}$ & $05 / 08 / 2005$ & $\begin{array}{l}\text { Associação dos } \\
\text { Magistrados } \\
\text { Brasileiros - AMB } \\
\end{array}$ \\
\hline 430 & $\begin{array}{l}\text { Mandado de } \\
\text { Segurança }\end{array}$ & 22127 & Não & Não & RS & Ellen Gracie & $19 / 08 / 2005$ & Paulo Cesar Lima \\
\hline 431 & $\begin{array}{l}\text { Recurso } \\
\text { Extraordinário }\end{array}$ & 428782 & Não & $\begin{array}{l}\text { Agravo } \\
\text { Regimental }\end{array}$ & DF & Cezar Peluso & $19 / 08 / 2005$ & $\begin{array}{l}\text { Antoniel Gomes } \\
\text { Ramos e outros }\end{array}$ \\
\hline 432 & $\begin{array}{l}\text { Agravo de } \\
\text { Instrumento }\end{array}$ & 490182 & Não & $\begin{array}{l}\text { Agravo } \\
\text { Regimental }\end{array}$ & RS & \begin{tabular}{|l} 
Carlos \\
Velloso \\
\end{tabular} & $26 / 08 / 2005$ & Kendi Érico Yoshida \\
\hline 433 & $\begin{array}{l}\text { Agravo de } \\
\text { Instrumento }\end{array}$ & 529714 & Não & $\begin{array}{l}\text { Agravo } \\
\text { Regimental }\end{array}$ & SP & $\begin{array}{l}\text { Joaquim } \\
\text { Barbosa }\end{array}$ & $26 / 08 / 2005$ & Rodrigo Fernandes \\
\hline 434 & $\begin{array}{l}\text { Mandado de } \\
\text { Segurança }\end{array}$ & 25091 & Não & Não & DF & $\begin{array}{l}\text { Marco } \\
\text { Aurélio }\end{array}$ & $26 / 08 / 2005$ & $\begin{array}{l}\text { Pedro Fernando Santa } \\
\text { Rita Carvalho de } \\
\text { Athayde } \\
\end{array}$ \\
\hline 435 & $\begin{array}{l}\text { Recurso } \\
\text { Extraordinário }\end{array}$ & 448536 & Não & $\begin{array}{l}\text { Agravo } \\
\text { Regimental }\end{array}$ & SC & \begin{tabular}{|l} 
Sepúlveda \\
Pertence
\end{tabular} & $16 / 09 / 2005$ & \begin{tabular}{|l} 
Sindicato dos \\
Trabalhadores em \\
Saúde e Previdência \\
do Serviço Público \\
Federal no Estado de \\
Santa Catarina - \\
SINDPREV/SC \\
\end{tabular} \\
\hline 436 & $\begin{array}{l}\text { Recurso } \\
\text { Extraordinário }\end{array}$ & 448792 & Não & $\begin{array}{l}\text { Agravo } \\
\text { Regimental }\end{array}$ & MG & $\begin{array}{l}\text { Joaquim } \\
\text { Barbosa } \\
\end{array}$ & $23 / 09 / 2005$ & $\begin{array}{l}\text { Sindicato dos } \\
\text { Trabalhadores no } \\
\text { Serviço Público } \\
\text { Federal no Estado de } \\
\text { Minas Gerais - } \\
\text { SINDSEF/MG } \\
\end{array}$ \\
\hline 437 & $\begin{array}{l}\text { Ação Direta de } \\
\text { Inconstitucionalidade }\end{array}$ & 11266 & Não & Não & $\mathrm{BA}$ & Eros Grau & $23 / 09 / 2005$ & \begin{tabular}{|l|} 
Confederação \\
Nacional dos \\
Estabelecimenos de \\
Ensino - COFENEN \\
\end{tabular} \\
\hline 438 & $\begin{array}{l}\text { Ação Direta de } \\
\text { Inconstitucionalidade }\end{array}$ & 3068 & Não & Não & DF & Eros Grau & $23 / 09 / 2005$ & $\begin{array}{l}\text { Partido da Frente } \\
\text { Liberal - PFL }\end{array}$ \\
\hline
\end{tabular}




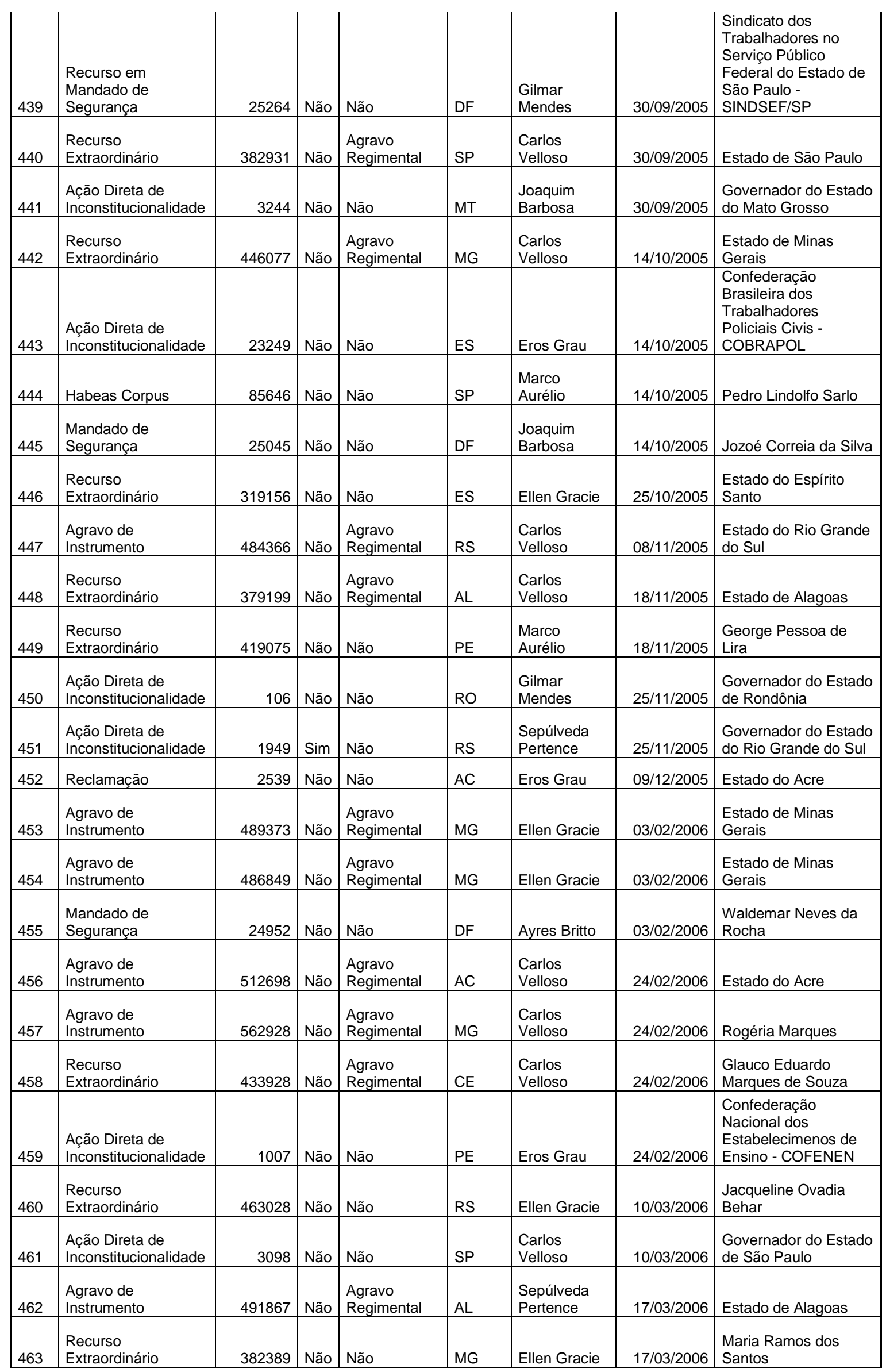




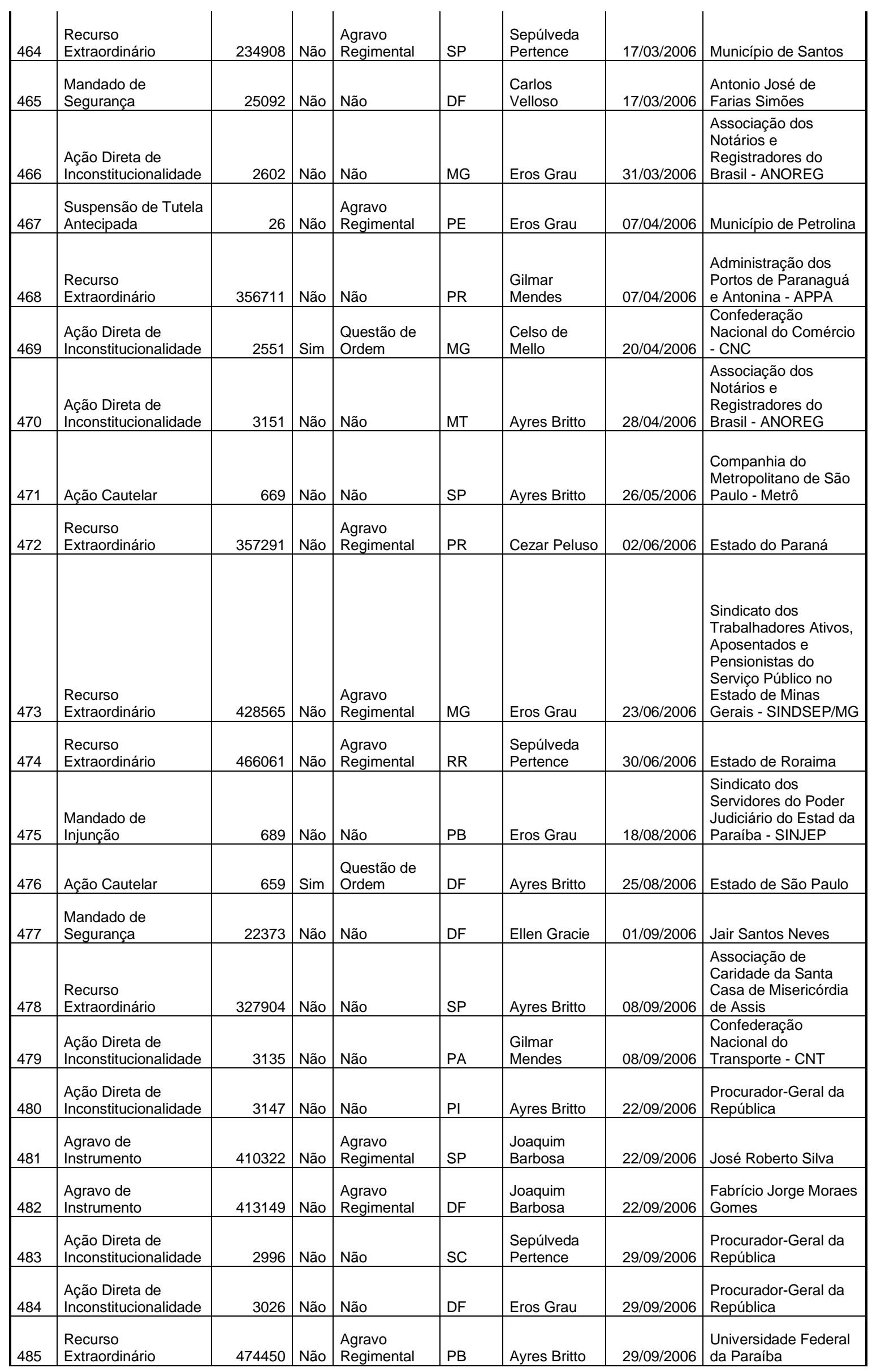




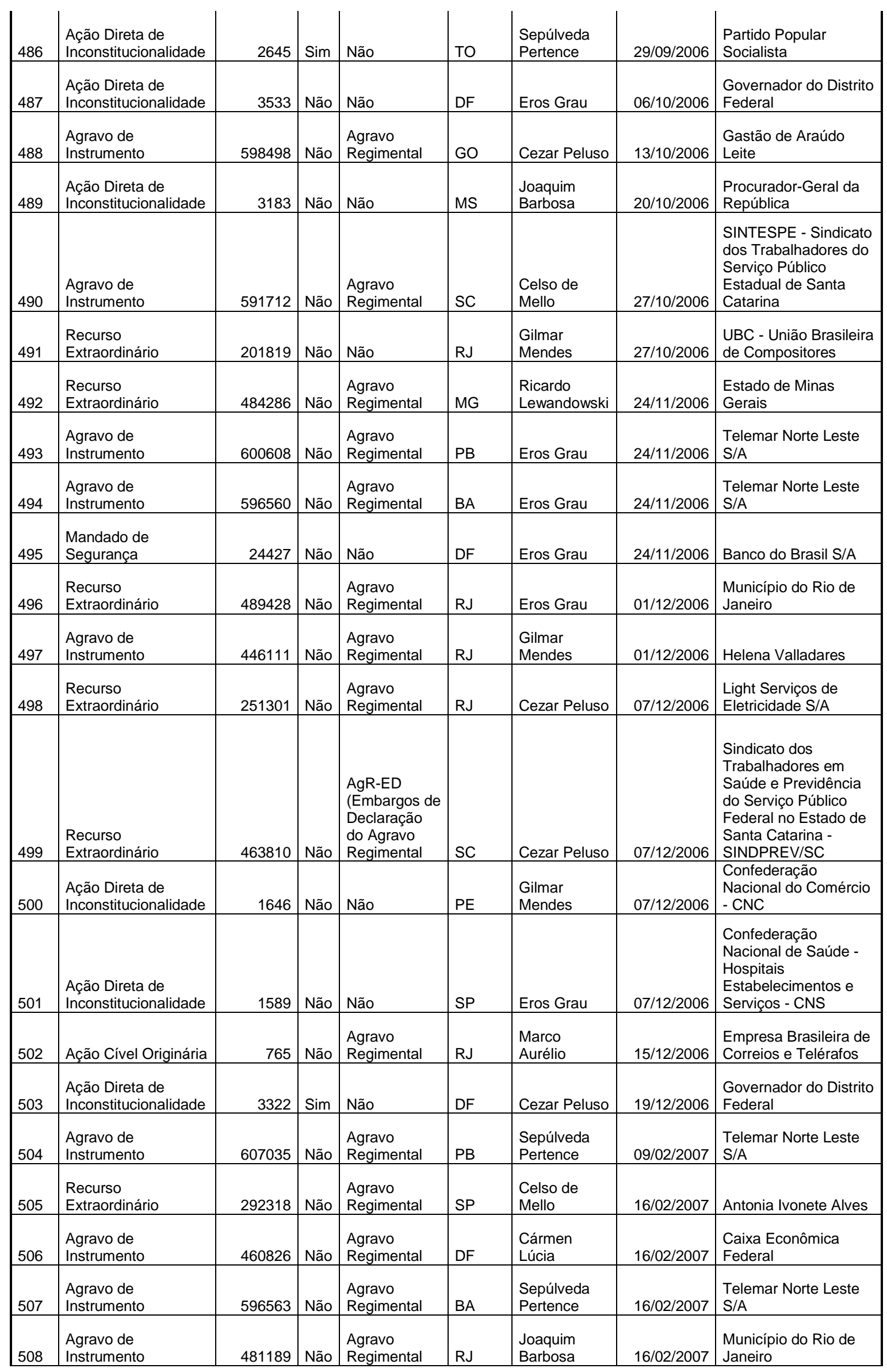




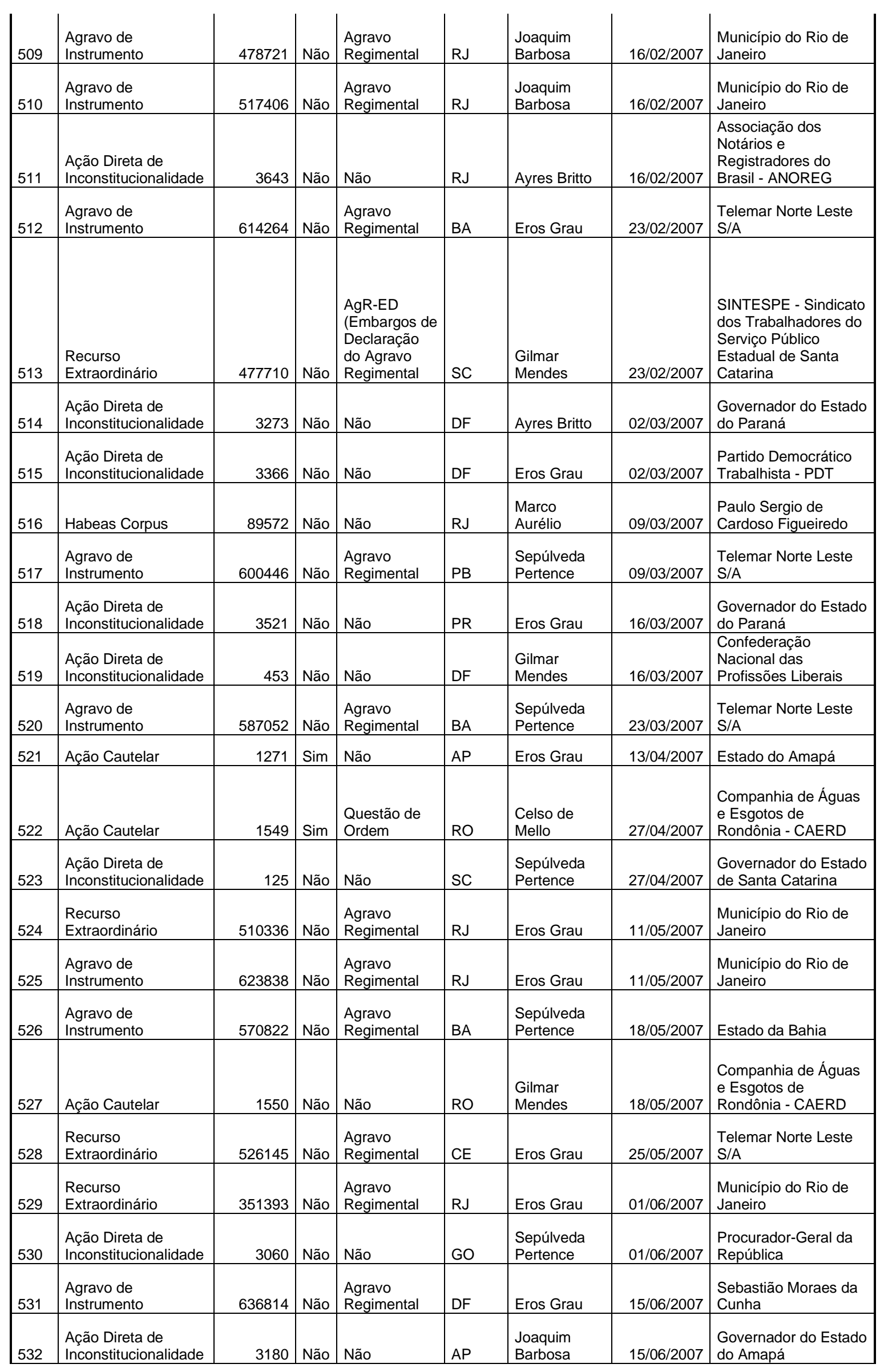




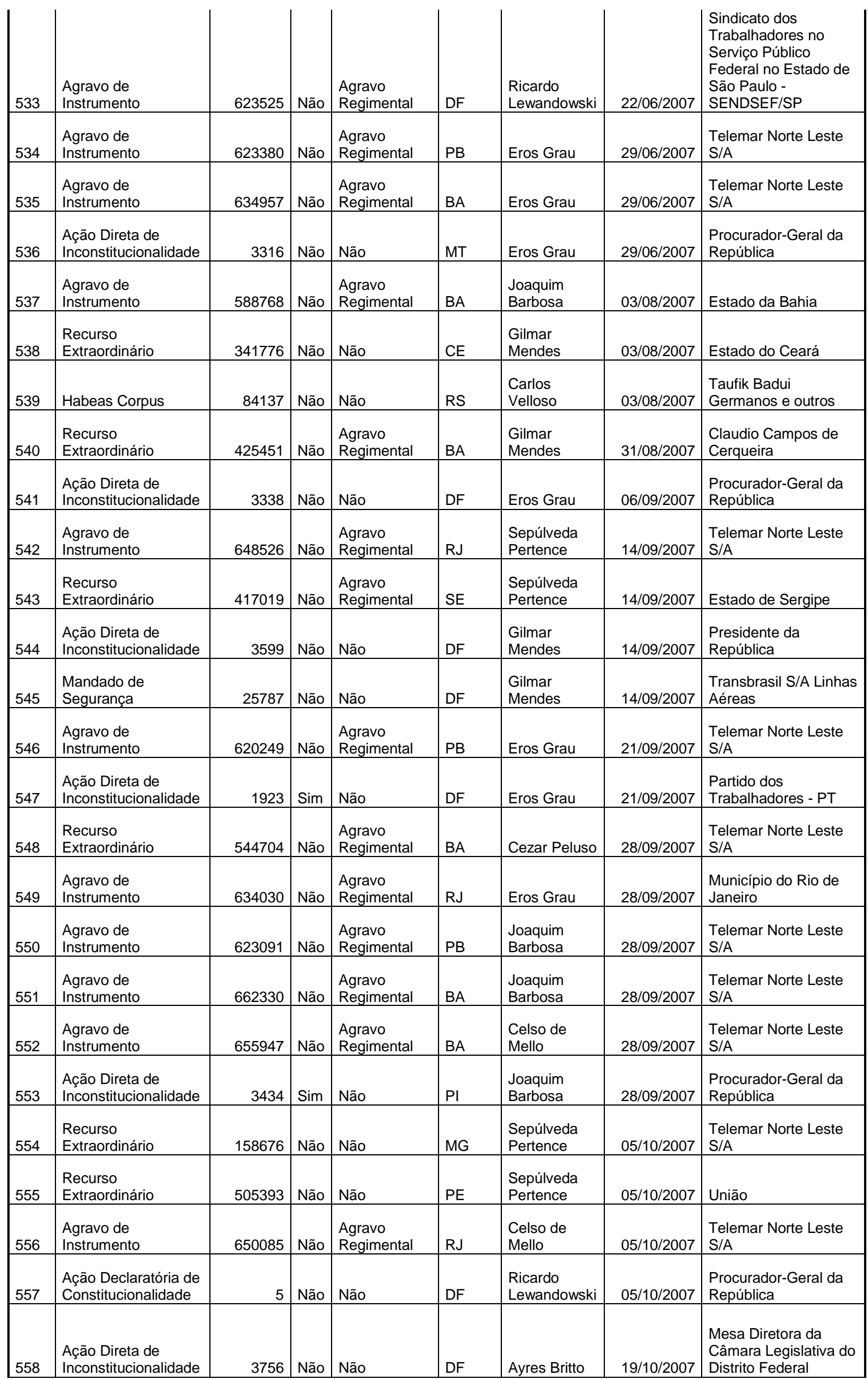




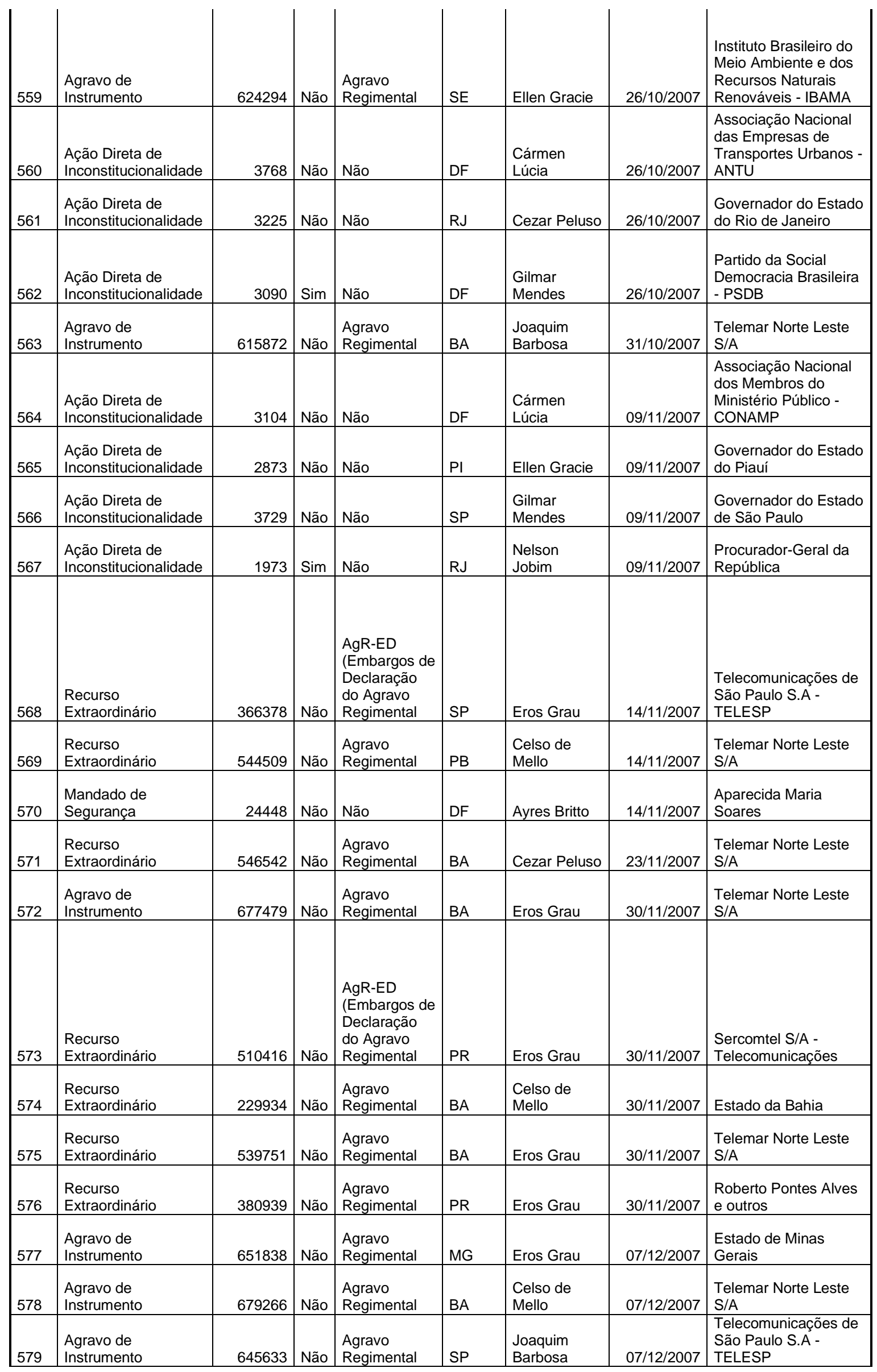




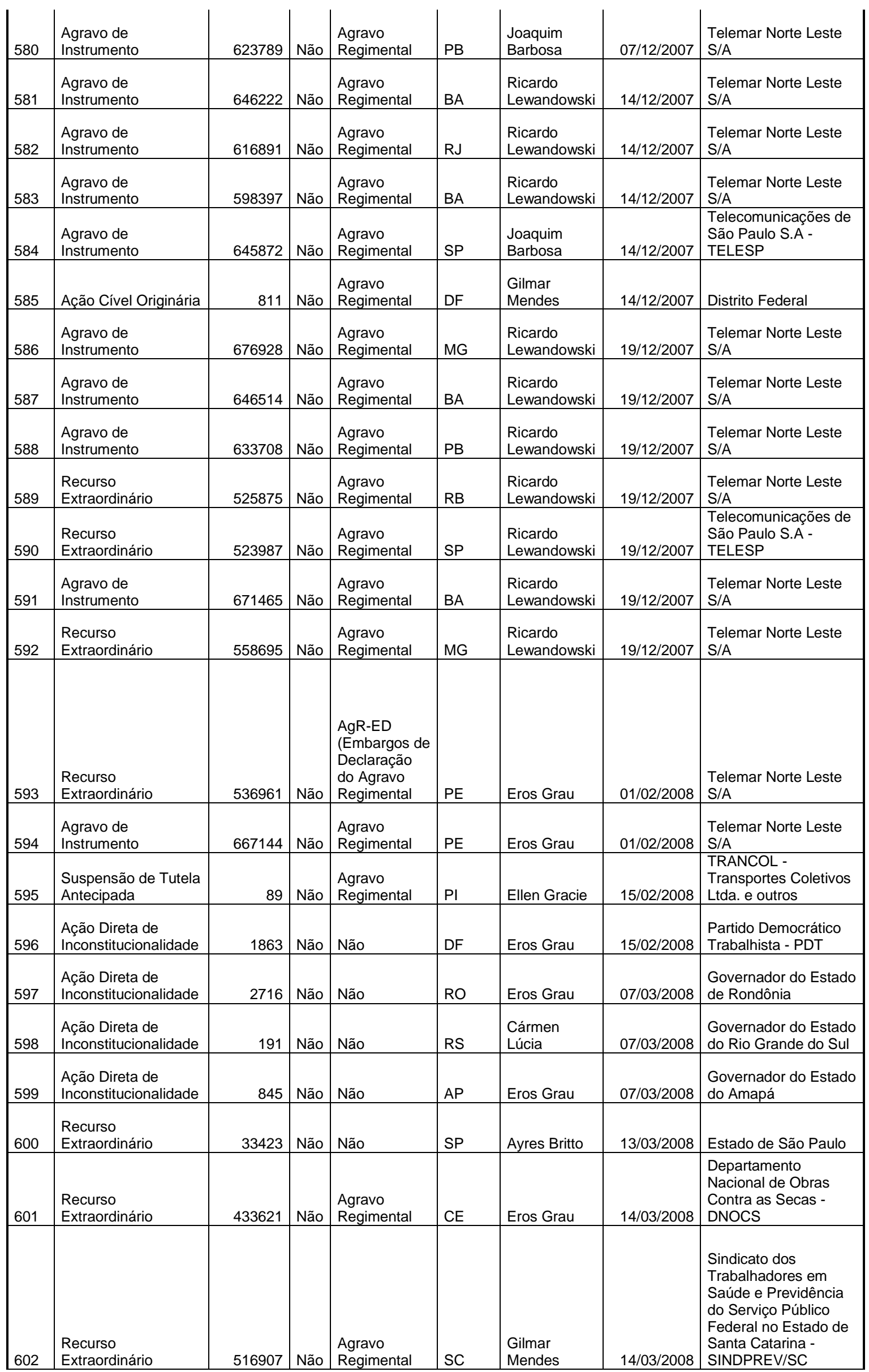




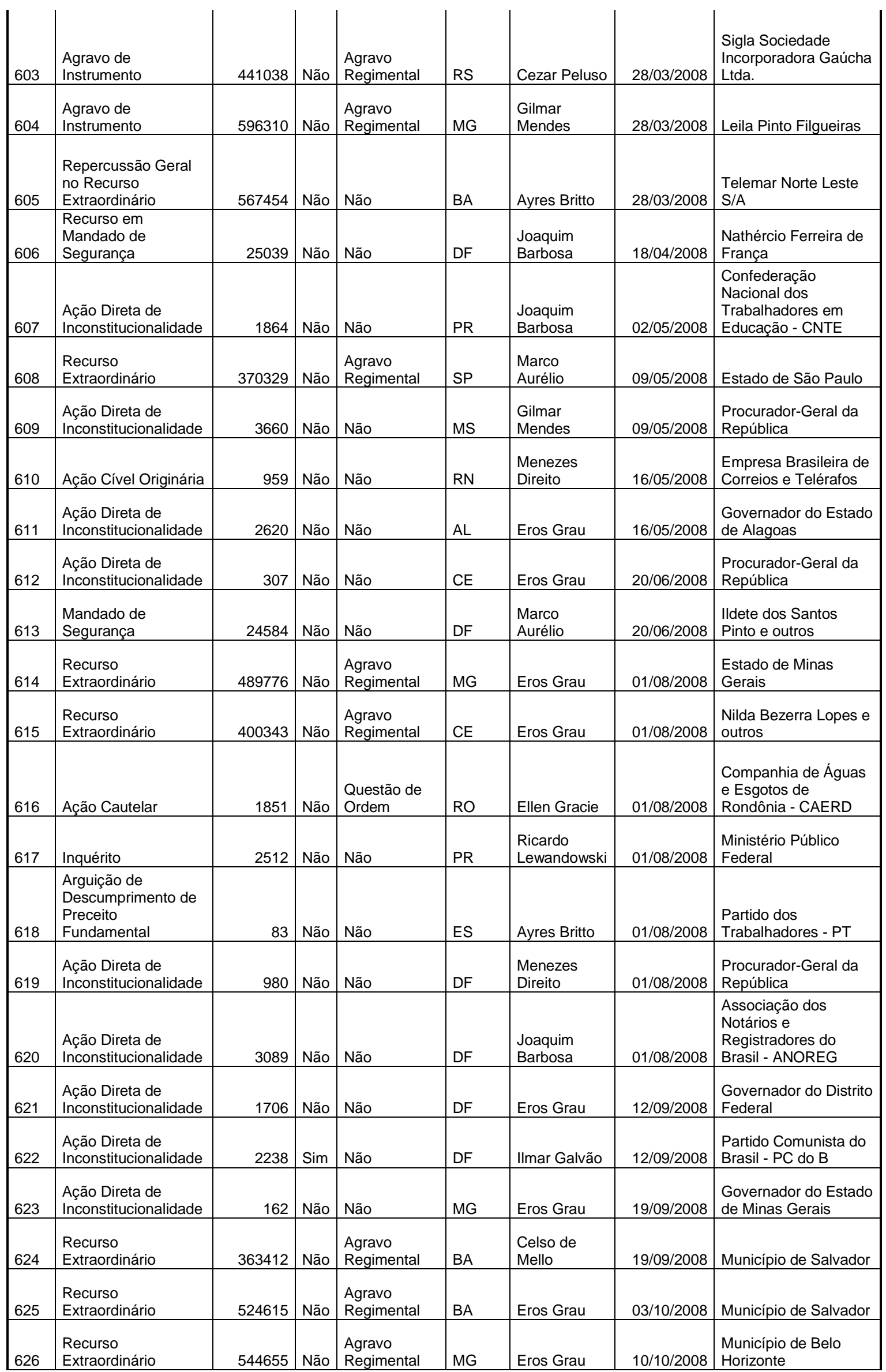




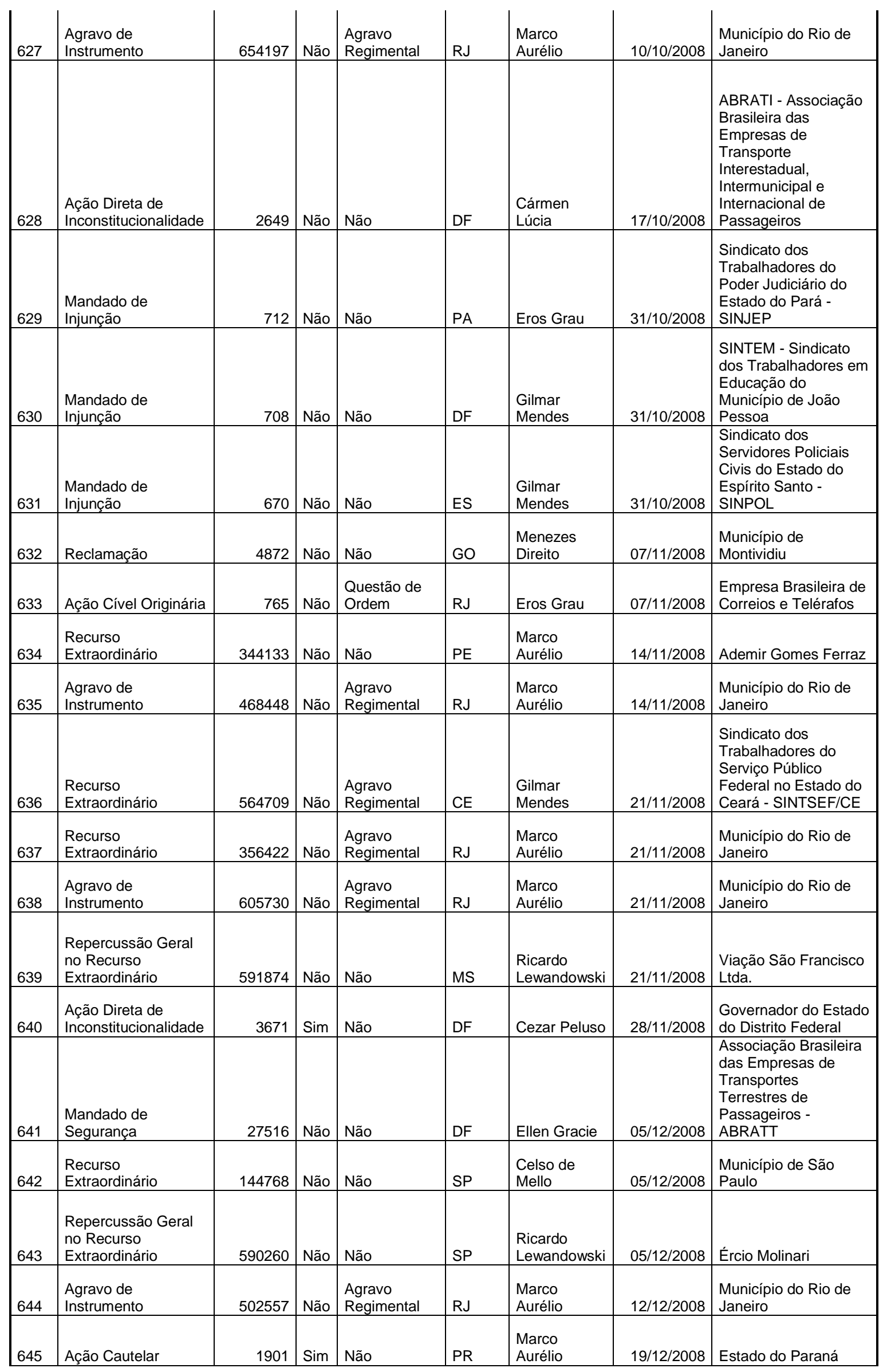




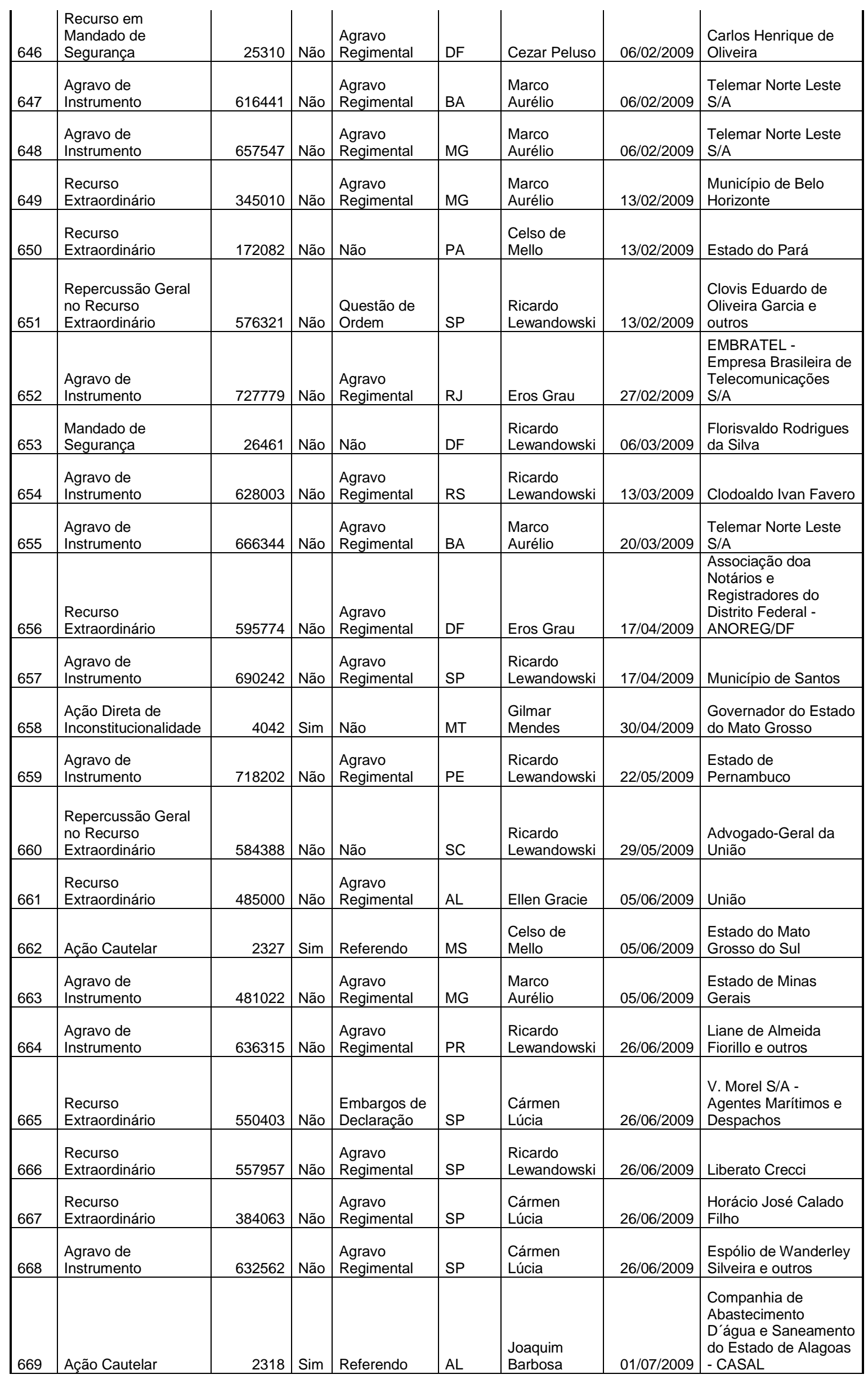




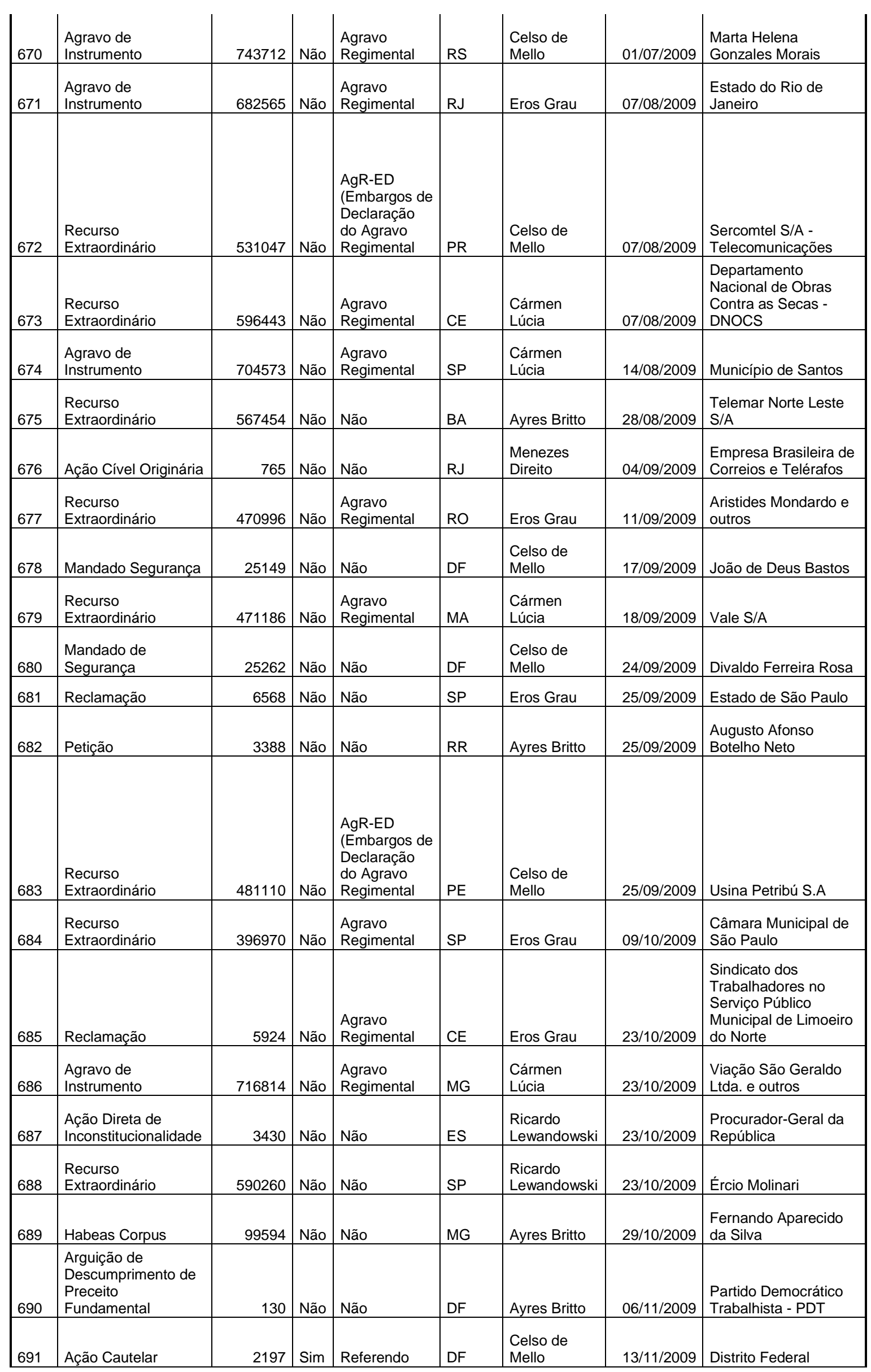




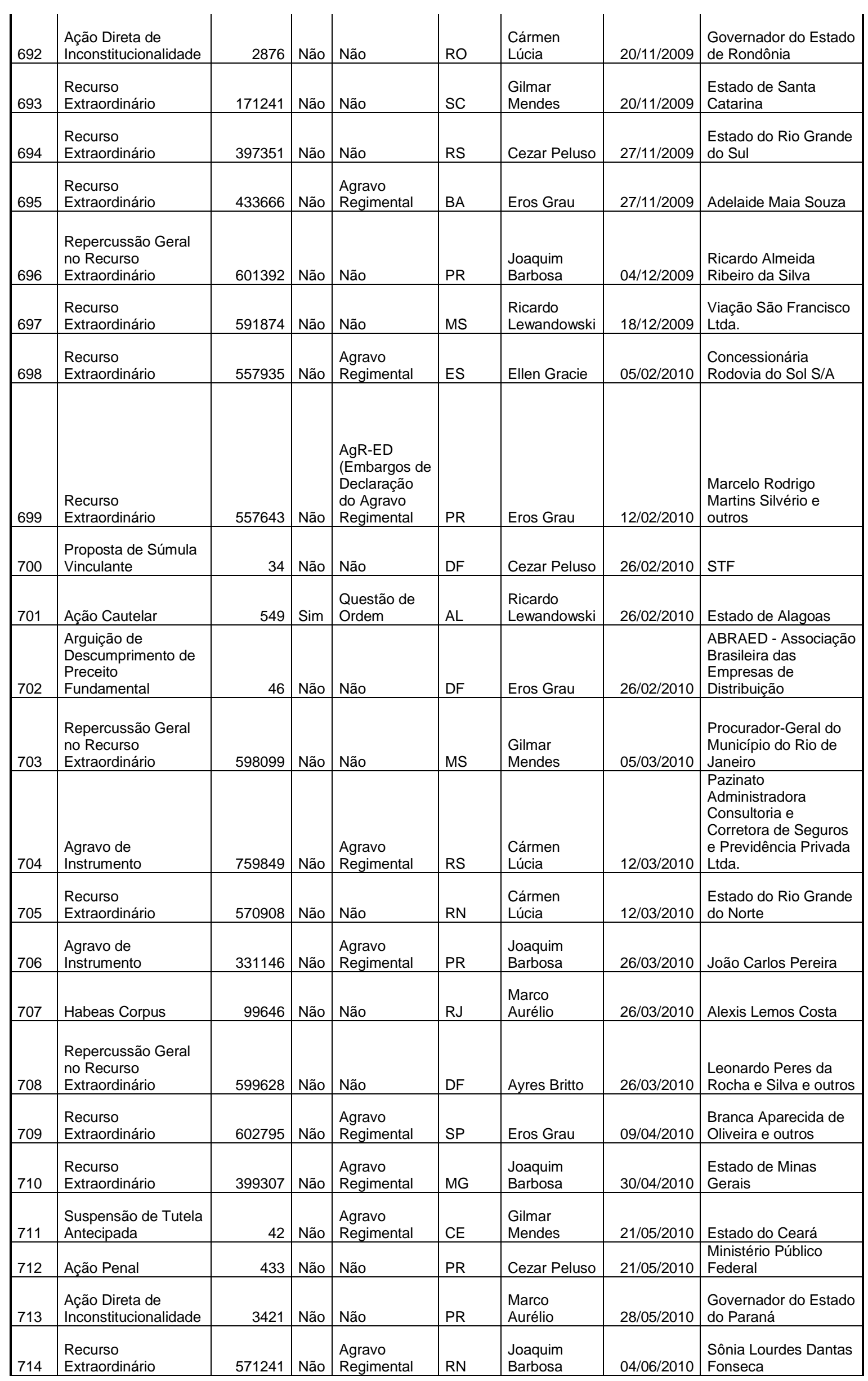




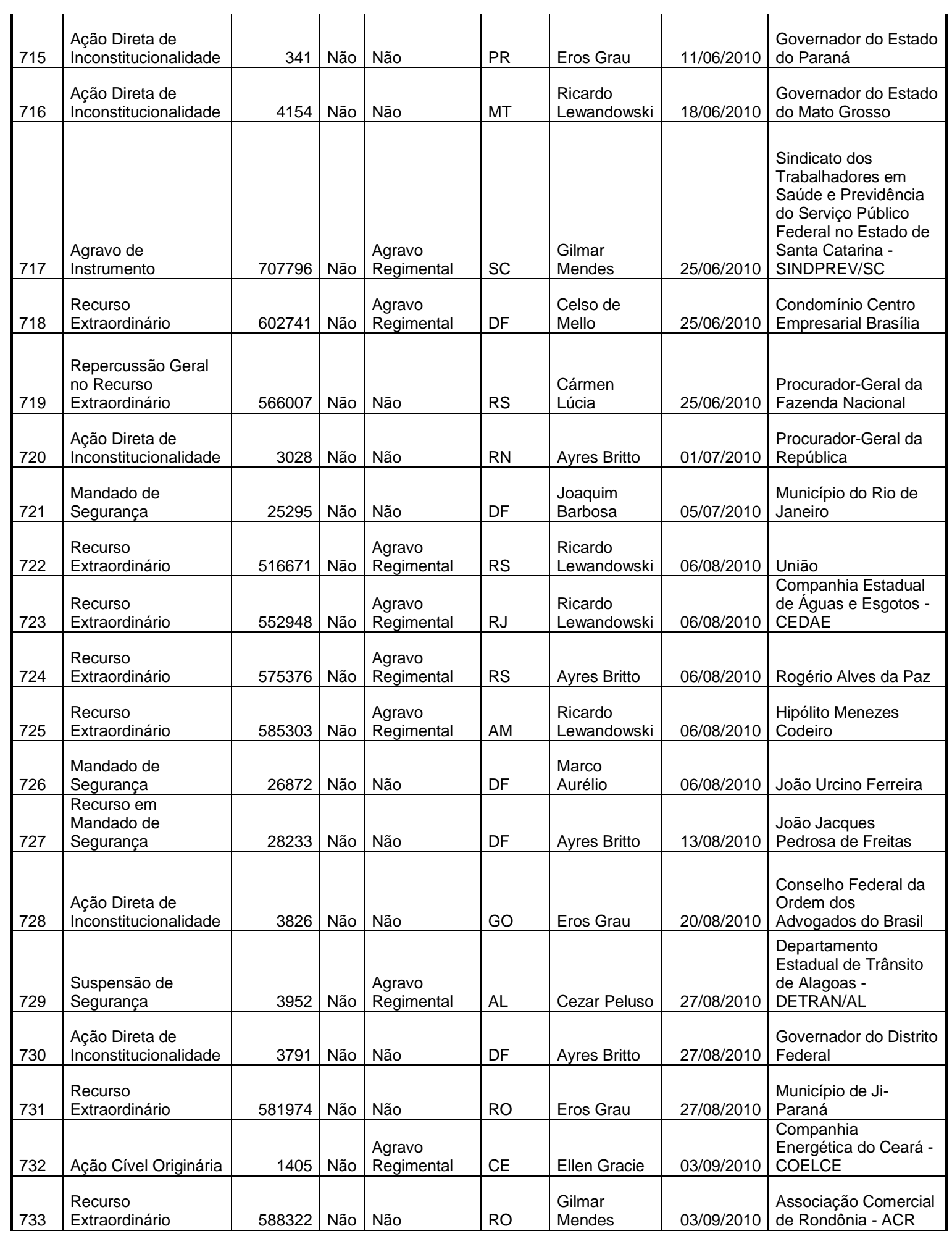




\begin{tabular}{|c|c|c|c|c|c|c|c|c|}
\hline 734 & \begin{tabular}{|l|} 
Recurso \\
Extraordinário \\
\end{tabular} & 465353 & Não & $\begin{array}{l}\text { Agr-ED-ED- } \\
\text { Edv-Agr } \\
\text { (Agravo } \\
\text { Regimental } \\
\text { nos } \\
\text { Embargos de } \\
\text { Divergência } \\
\text { nos } \\
\text { Embargos de } \\
\text { Declaração } \\
\text { nos } \\
\text { Embargos de } \\
\text { Declaração } \\
\text { no Agravo } \\
\text { Regimental) } \\
\end{array}$ & SC & $\begin{array}{l}\text { Cármen } \\
\text { Lúcia }\end{array}$ & $10 / 09 / 2010$ & $\begin{array}{l}\text { Sindicato dos } \\
\text { Trabalhadores em } \\
\text { Saúde e Previdência } \\
\text { do Serviço Público } \\
\text { Federal no Estado de } \\
\text { Santa Catarina - } \\
\text { SINDPREV/SC }\end{array}$ \\
\hline 735 & $\begin{array}{l}\text { Recurso } \\
\text { Extraordinário }\end{array}$ & 580329 & Não & \begin{tabular}{|l} 
Agravo \\
Regimental \\
\end{tabular} & RJ & Ayres Britto & $17 / 09 / 2010$ & $\begin{array}{l}\text { Transportes Zona } \\
\text { Oeste Ltda. }\end{array}$ \\
\hline 736 & $\begin{array}{l}\text { Ação Direta de } \\
\text { Inconstitucionalidade }\end{array}$ & 2452 & Não & Não & SP & Eros Grau & $17 / 09 / 2010$ & $\begin{array}{l}\text { Governador do Estado } \\
\text { de Minas Gerais }\end{array}$ \\
\hline 737 & $\begin{array}{l}\text { Ação Direta de } \\
\text { Inconstitucionalidade }\end{array}$ & 336 & Não & Não & SE & Eros Grau & $17 / 09 / 2010$ & $\begin{array}{l}\text { Governador do Estado } \\
\text { de Sergipe }\end{array}$ \\
\hline 738 & $\begin{array}{l}\text { Agravo de } \\
\text { Instrumento }\end{array}$ & 791915 & Não & $\begin{array}{l}\text { Agravo } \\
\text { Regimental }\end{array}$ & MG & $\begin{array}{l}\text { Cármen } \\
\text { Lúcia }\end{array}$ & $24 / 09 / 2010$ & $\begin{array}{l}\text { Expresso Santa Luzia } \\
\text { Ltda. }\end{array}$ \\
\hline 739 & $\begin{array}{l}\text { Agravo de } \\
\text { Instrumento }\end{array}$ & 531823 & Não & \begin{tabular}{|l} 
Agravo \\
Regimental
\end{tabular} & RJ & $\begin{array}{l}\text { Joaquim } \\
\text { Barbosa }\end{array}$ & $01 / 10 / 2010$ & $\begin{array}{l}\text { Município do Rio de } \\
\text { Janeiro }\end{array}$ \\
\hline 740 & $\begin{array}{l}\text { Ação Direta de } \\
\text { Inconstitucionalidade }\end{array}$ & 3944 & Não & Não & DF & Ayres Britto & $01 / 10 / 2010$ & $\begin{array}{l}\text { Partido Socialismo e } \\
\text { Liberdade - PSOL }\end{array}$ \\
\hline 741 & $\begin{array}{l}\text { Agravo de } \\
\text { Instrumento }\end{array}$ & 623395 & Não & \begin{tabular}{|l} 
Agravo \\
Regimental
\end{tabular} & AP & $\begin{array}{l}\text { Joaquim } \\
\text { Barbosa }\end{array}$ & $08 / 10 / 2010$ & Estado do Amapá \\
\hline 742 & $\begin{array}{l}\text { Agravo de } \\
\text { Instrumento }\end{array}$ & 593503 & Não & $\begin{array}{l}\text { Agravo } \\
\text { Regimental } \\
\end{array}$ & SP & $\begin{array}{l}\text { Joaquim } \\
\text { Barbosa } \\
\end{array}$ & $08 / 10 / 2010$ & $\begin{array}{l}\text { Ciágua } \\
\text { Concessionária de } \\
\text { Águas de Mairinque } \\
\text { Ltda. e outros }\end{array}$ \\
\hline 743 & $\begin{array}{l}\text { Agravo de } \\
\text { Instrumento }\end{array}$ & 800821 & Não & $\begin{array}{l}\text { Agravo } \\
\text { Regimental }\end{array}$ & PR & $\begin{array}{l}\text { Cármen } \\
\text { Lúcia }\end{array}$ & 08/10/2010 & $\begin{array}{l}\text { Almir Augustinho de } \\
\text { Almeida e outro }\end{array}$ \\
\hline 744 & Ação Cível Originária & 789 & Não & Não & $\mathrm{PI}$ & Dias Toffoli & $15 / 10 / 2010$ & $\begin{array}{l}\text { Empresa Brasileira de } \\
\text { Correios e Telérafos }\end{array}$ \\
\hline 745 & $\begin{array}{l}\text { Agravo de } \\
\text { Instrumento }\end{array}$ & 665967 & Não & $\begin{array}{l}\text { Agravo } \\
\text { Regimental }\end{array}$ & PR & $\begin{array}{l}\text { Marco } \\
\text { Aurélio }\end{array}$ & $15 / 10 / 2010$ & Alexssandro de Souza \\
\hline 746 & $\begin{array}{l}\text { Agravo de } \\
\text { Instrumento }\end{array}$ & 712893 & Não & $\begin{array}{l}\text { Agravo } \\
\text { Regimental }\end{array}$ & RS & Dias Toffoli & $25 / 10 / 2010$ & $\begin{array}{l}\text { Cleidon Aldo de } \\
\text { Moura Peixoto }\end{array}$ \\
\hline 747 & $\begin{array}{l}\text { Recurso } \\
\text { Extraordinário }\end{array}$ & 596729 & Não & \begin{tabular}{|l} 
Agravo \\
Regimental
\end{tabular} & $\mathrm{SC}$ & $\begin{array}{l}\text { Ricardo } \\
\text { Lewandowski }\end{array}$ & $10 / 11 / 2010$ & $\begin{array}{l}\text { Companhia Nacional } \\
\text { de Abastecimento - } \\
\text { CONAB }\end{array}$ \\
\hline 748 & Ação Cautelar & 2636 & Sim & Referendo & $\mathrm{PE}$ & $\begin{array}{l}\text { Cármen } \\
\text { Lúcia }\end{array}$ & $11 / 11 / 2010$ & $\begin{array}{l}\text { Fundação Nacional de } \\
\text { Hematologia e } \\
\text { Hemoterapia de } \\
\text { Pernambuco - } \\
\text { HEMOPE }\end{array}$ \\
\hline 749 & $\begin{array}{l}\text { Agravo de } \\
\text { Instrumento }\end{array}$ & 791506 & Não & $\begin{array}{l}\text { Agravo } \\
\text { Regimental } \\
\end{array}$ & BA & $\begin{array}{l}\text { Ricardo } \\
\text { Lewandowski } \\
\end{array}$ & $16 / 11 / 2010$ & $\begin{array}{l}\text { Sindicato dos } \\
\text { Sevidores da } \\
\text { Fundação Nacional de } \\
\text { Saúde no Estado da } \\
\text { Bahia - } \\
\text { SINDSFUNSEB } \\
\end{array}$ \\
\hline 750 & $\begin{array}{l}\text { Agravo de } \\
\text { Instrumento }\end{array}$ & 794192 & Não & \begin{tabular}{|l} 
Agravo \\
Regimental
\end{tabular} & DF & $\begin{array}{l}\text { Ricardo } \\
\text { Lewandowski }\end{array}$ & $16 / 11 / 2010$ & $\begin{array}{l}\text { Andre Napoli de } \\
\text { Nardiello e outros }\end{array}$ \\
\hline
\end{tabular}




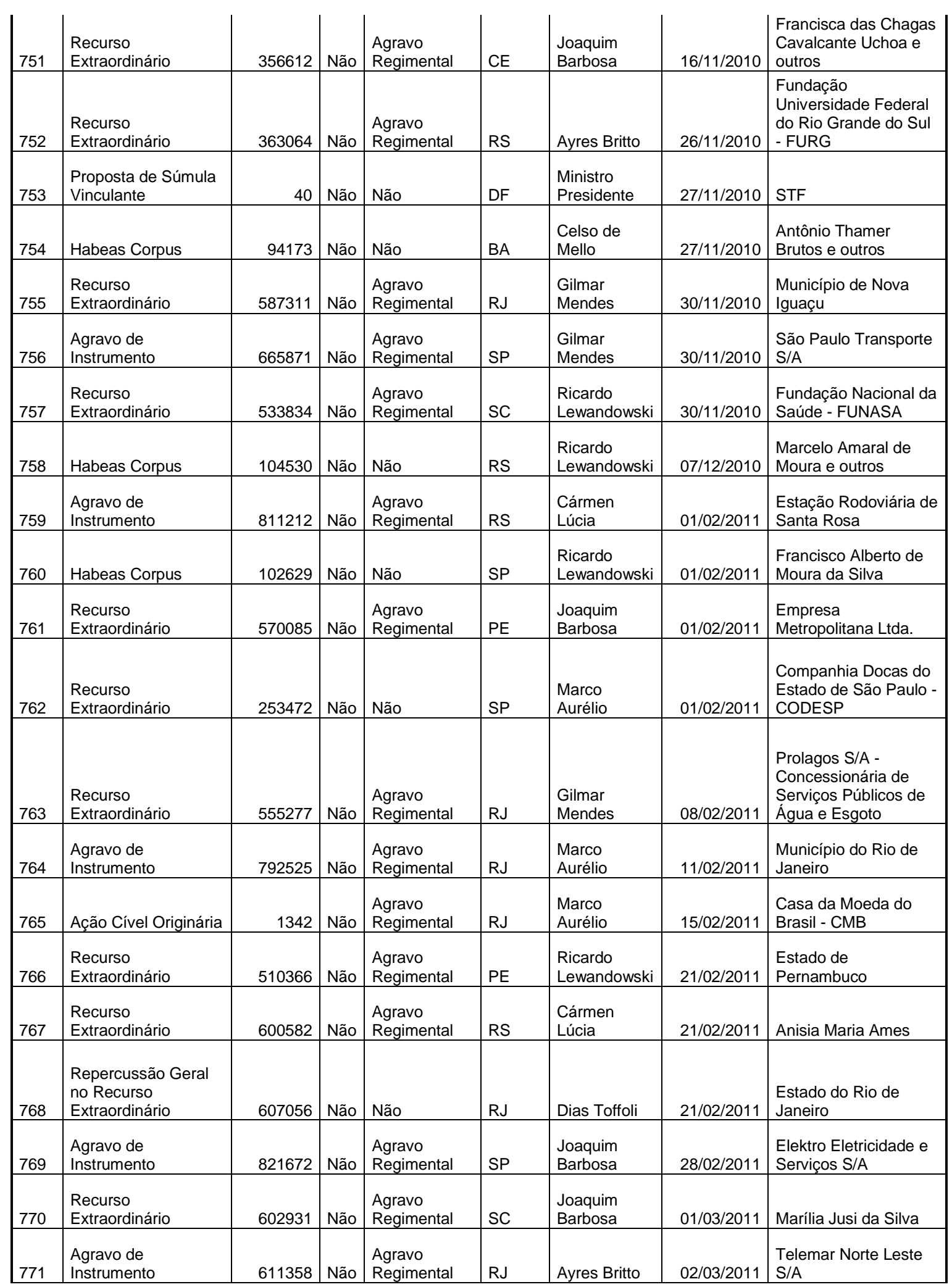




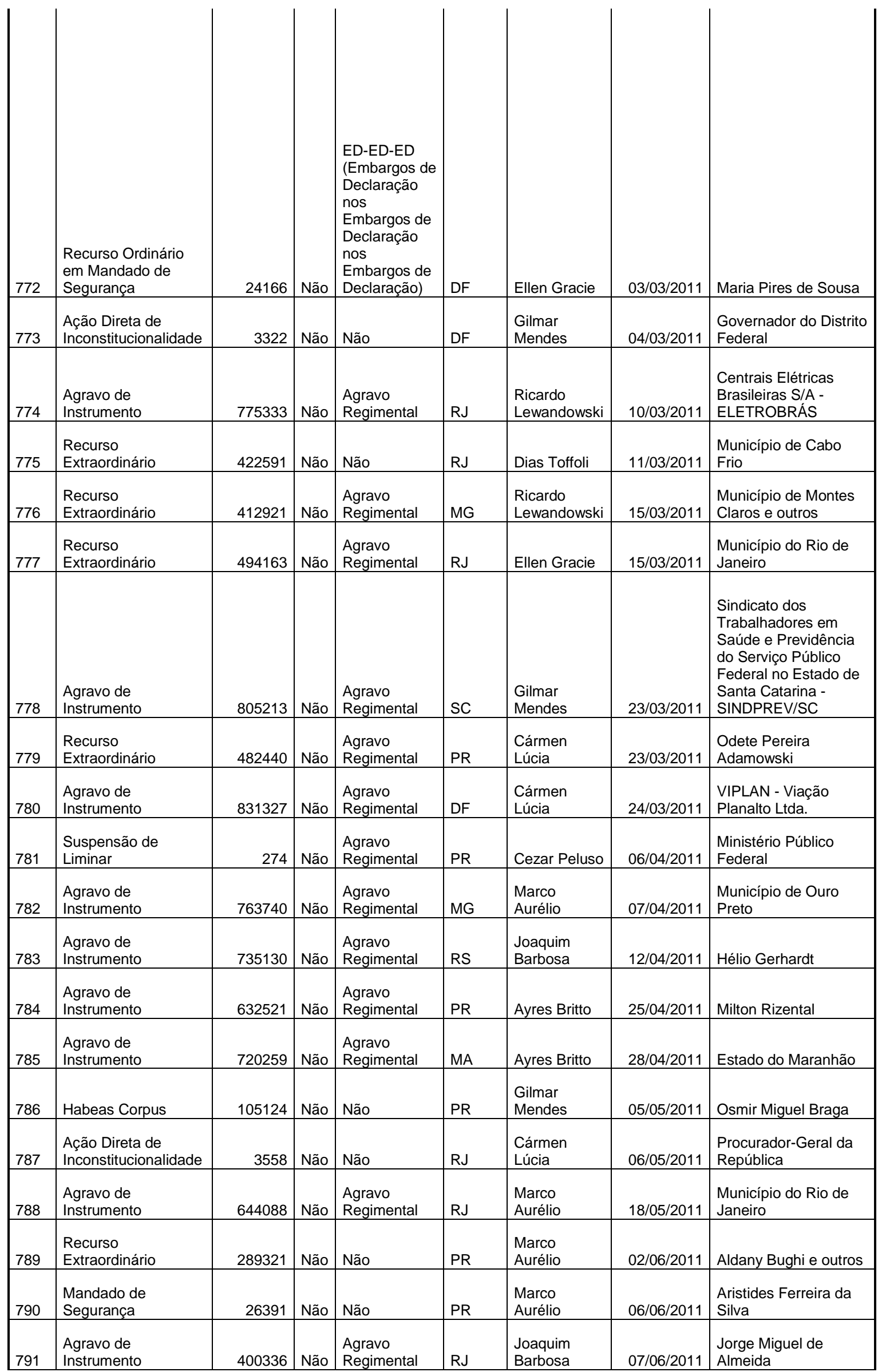




\begin{tabular}{|c|c|c|c|c|c|c|c|c|}
\hline 792 & $\begin{array}{l}\text { Repercussão Geral } \\
\text { no Recurso } \\
\text { Extraordinário }\end{array}$ & 627051 & Não & Não & $\mathrm{PE}$ & Dias Toffoli & $16 / 06 / 2011$ & $\begin{array}{l}\text { Empresa Brasileira de } \\
\text { Correios e Telégrafos }\end{array}$ \\
\hline 793 & $\begin{array}{l}\text { Recurso } \\
\text { Extraordinário } \\
\end{array}$ & 571668 & Não & $\begin{array}{l}\text { Agravo } \\
\text { Regimental } \\
\end{array}$ & SC & Ellen Gracie & $24 / 06 / 2011$ & $\begin{array}{l}\text { Município de } \\
\text { Blumenau } \\
\end{array}$ \\
\hline 794 & $\begin{array}{l}\text { Agravo de } \\
\text { Instrumento }\end{array}$ & 845209 & Não & $\begin{array}{l}\text { Agravo } \\
\text { Regimental }\end{array}$ & SE & $\begin{array}{l}\text { Gilmar } \\
\text { Mendes }\end{array}$ & $29 / 06 / 2011$ & $\begin{array}{l}\text { Sindicato dos } \\
\text { Trabalhadores do } \\
\text { Serviço Público } \\
\text { Federal no Estado de } \\
\text { Sergipe - SINTSEP }\end{array}$ \\
\hline 795 & $\begin{array}{l}\text { Agravo de } \\
\text { Instrumento }\end{array}$ & 663090 & Não & $\begin{array}{l}\text { Agravo } \\
\text { Regimental }\end{array}$ & $\mathrm{SP}$ & $\begin{array}{l}\text { Cármen } \\
\text { Lúcia }\end{array}$ & $01 / 07 / 2011$ & $\begin{array}{l}\text { Município de São } \\
\text { Paulo }\end{array}$ \\
\hline 796 & $\begin{array}{l}\text { Ação Direta de } \\
\text { Inconstitucionalidade }\end{array}$ & 4451 & Sim & Referendo & DF & Ayres Britto & $01 / 07 / 2011$ & $\begin{array}{l}\text { Associação Brasileira } \\
\text { de Emissoras de } \\
\text { Rádio e Televisão - } \\
\text { ABERT }\end{array}$ \\
\hline 797 & $\begin{array}{l}\text { Agravo de } \\
\text { Instrumento }\end{array}$ & 701403 & Não & \begin{tabular}{|l} 
Agravo \\
Regimental \\
\end{tabular} & RJ & \begin{tabular}{|l|} 
Joaquim \\
Barbosa \\
\end{tabular} & $01 / 08 / 2011$ & $\begin{array}{l}\text { Município do Rio de } \\
\text { Janeiro }\end{array}$ \\
\hline 798 & $\begin{array}{l}\text { Agravo de } \\
\text { Instrumento }\end{array}$ & 825659 & Não & \begin{tabular}{|l} 
Agravo \\
Regimental
\end{tabular} & SP & $\begin{array}{l}\text { Marco } \\
\text { Aurélio } \\
\end{array}$ & $16 / 08 / 2011$ & Autovias S/A \\
\hline 799 & $\begin{array}{l}\text { Agravo de } \\
\text { Instrumento }\end{array}$ & 617917 & Não & $\begin{array}{l}\text { Agravo } \\
\text { Regimental }\end{array}$ & MG & Dias Toffoli & $18 / 08 / 2011$ & $\begin{array}{l}\text { Jamis Milland } \\
\text { Resende Torres }\end{array}$ \\
\hline 800 & $\begin{array}{l}\text { Recurso } \\
\text { Extraordinário }\end{array}$ & 613287 & Não & \begin{tabular}{|l} 
Agravo \\
Regimental \\
\end{tabular} & RS & Luiz Fux & 19/08/2011 & União \\
\hline 801 & $\begin{array}{l}\text { Recurso } \\
\text { Extraordinário }\end{array}$ & 265749 & Não & $\begin{array}{l}\text { ED-ED } \\
\text { (Embargos de } \\
\text { Declaração } \\
\text { nos } \\
\text { Embargos de } \\
\text { Declaração) } \\
\end{array}$ & SP & $\begin{array}{l}\text { Celso de } \\
\text { Mello }\end{array}$ & $22 / 08 / 2011$ & Município de Santos \\
\hline 802 & $\begin{array}{l}\text { Agravo de } \\
\text { Instrumento }\end{array}$ & 351888 & Não & \begin{tabular}{|l} 
Agravo \\
Regimental
\end{tabular} & SP & $\begin{array}{l}\text { Celso de } \\
\text { Mello }\end{array}$ & $22 / 08 / 2011$ & Município de Santos \\
\hline 803 & $\begin{array}{l}\text { Agravo de } \\
\text { Instrumento }\end{array}$ & 661056 & Não & $\begin{array}{l}\text { Agravo } \\
\text { Regimental } \\
\end{array}$ & $\mathrm{RR}$ & Dias Toffoli & $24 / 08 / 2011$ & Estado de Roraima \\
\hline 804 & $\begin{array}{l}\text { Agravo de } \\
\text { Instrumento }\end{array}$ & 779629 & Não & \begin{tabular}{|l} 
Agravo \\
Regimental \\
\end{tabular} & MG & Ayres Britto & $25 / 08 / 2011$ & $\begin{array}{l}\text { Megabus Transportes } \\
\text { Ltda. }\end{array}$ \\
\hline 805 & $\begin{array}{l}\text { Recurso } \\
\text { Extraordinário }\end{array}$ & 573683 & Não & $\begin{array}{l}\text { Agravo } \\
\text { Regimental }\end{array}$ & BA & Ayres Britto & $26 / 08 / 2011$ & $\begin{array}{l}\text { Walfredo Elpídio da } \\
\text { Silva }\end{array}$ \\
\hline 806 & $\begin{array}{l}\text { Repercussão Geral } \\
\text { no ARE (Recurso } \\
\text { Extraordinário com } \\
\text { Agravo) }\end{array}$ & 638315 & Não & Não & $\mathrm{BA}$ & $\begin{array}{l}\text { Ministro } \\
\text { Presidente } \\
\end{array}$ & $31 / 08 / 2011$ & Município de Salvador \\
\hline 807 & $\begin{array}{l}\text { Repercussão Geral } \\
\text { no Agravo de } \\
\text { Instrumento }\end{array}$ & 839695 & Não & Não & $\mathrm{AM}$ & $\begin{array}{l}\text { Ministro } \\
\text { Presidente } \\
\end{array}$ & $01 / 09 / 2011$ & \begin{tabular}{|l} 
Amazonas \\
Distribuidora de \\
Energia S/A \\
\end{tabular} \\
\hline 808 & $\begin{array}{l}\text { Repercussão Geral } \\
\text { no Agravo de } \\
\text { Instrumento }\end{array}$ & 844777 & Não & Não & RJ & \begin{tabular}{|l} 
Ministro \\
Presidente \\
\end{tabular} & $01 / 09 / 2011$ & $\begin{array}{l}\text { Telemar Norte Leste } \\
\text { S/A }\end{array}$ \\
\hline 809 & \begin{tabular}{|l} 
Recurso \\
Extraordinário \\
\end{tabular} & 478058 & Não & $\begin{array}{l}\text { Embargos de } \\
\text { Declaração } \\
\end{array}$ & $\mathrm{RS}$ & $\begin{array}{l}\text { Ricardo } \\
\text { Lewandowski }\end{array}$ & $12 / 09 / 2011$ & Ivo dos Santos Rocha \\
\hline 810 & $\begin{array}{l}\text { Agravo de } \\
\text { Instrumento }\end{array}$ & 798493 & Não & \begin{tabular}{|l} 
Agravo \\
Regimental
\end{tabular} & RJ & Luiz Fux & 15/09/2011 & $\begin{array}{l}\text { Município do Rio de } \\
\text { Janeiro }\end{array}$ \\
\hline 811 & $\begin{array}{l}\text { Recurso } \\
\text { Extraordinário }\end{array}$ & 117809 & Não & Não & PR & $\begin{array}{l}\text { Cármen } \\
\text { Lúcia }\end{array}$ & 20/09/2011 & $\begin{array}{l}\text { Companhia de } \\
\text { Saneamento do } \\
\text { Paraná - SANEPAR }\end{array}$ \\
\hline
\end{tabular}




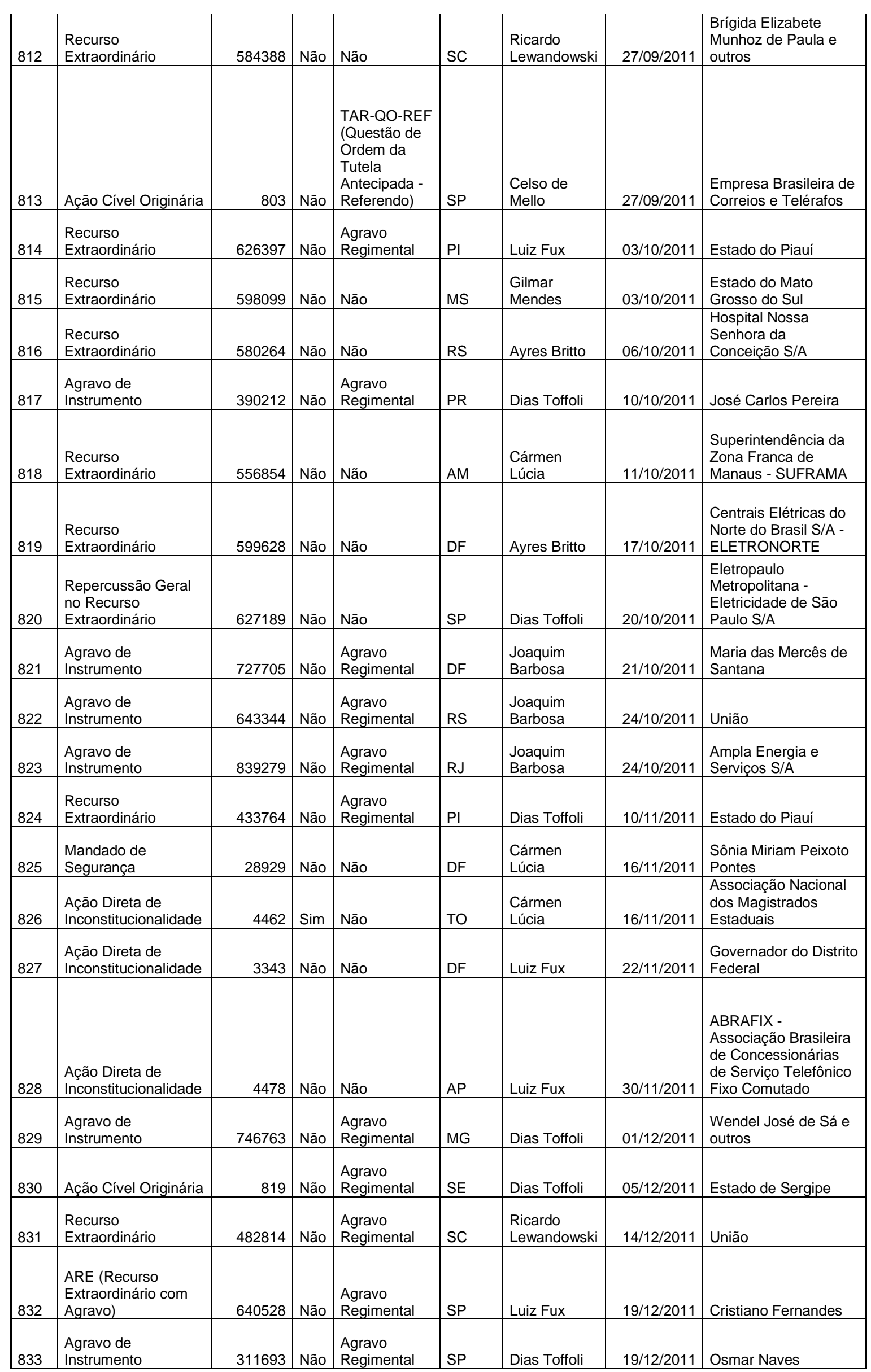




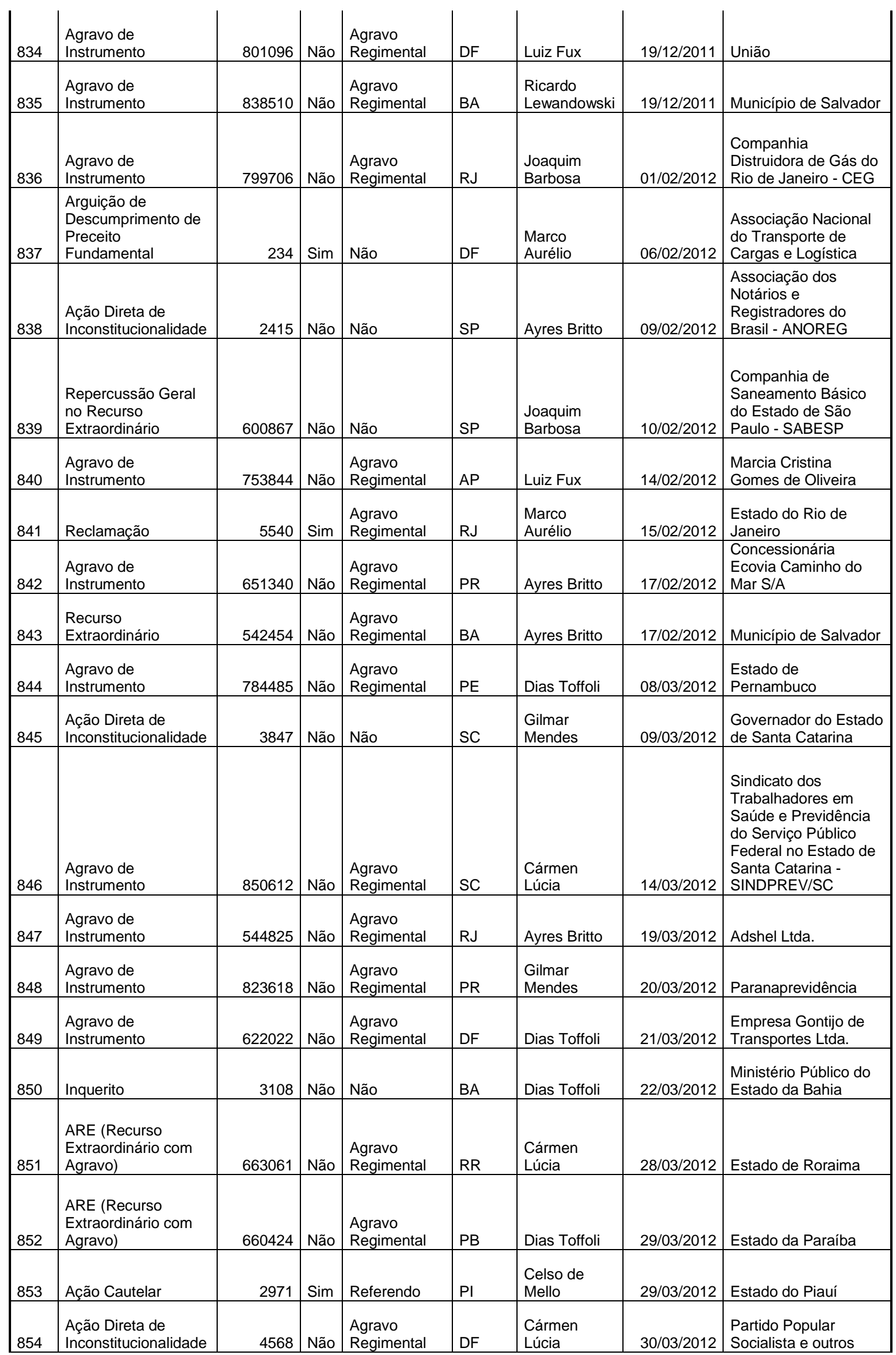




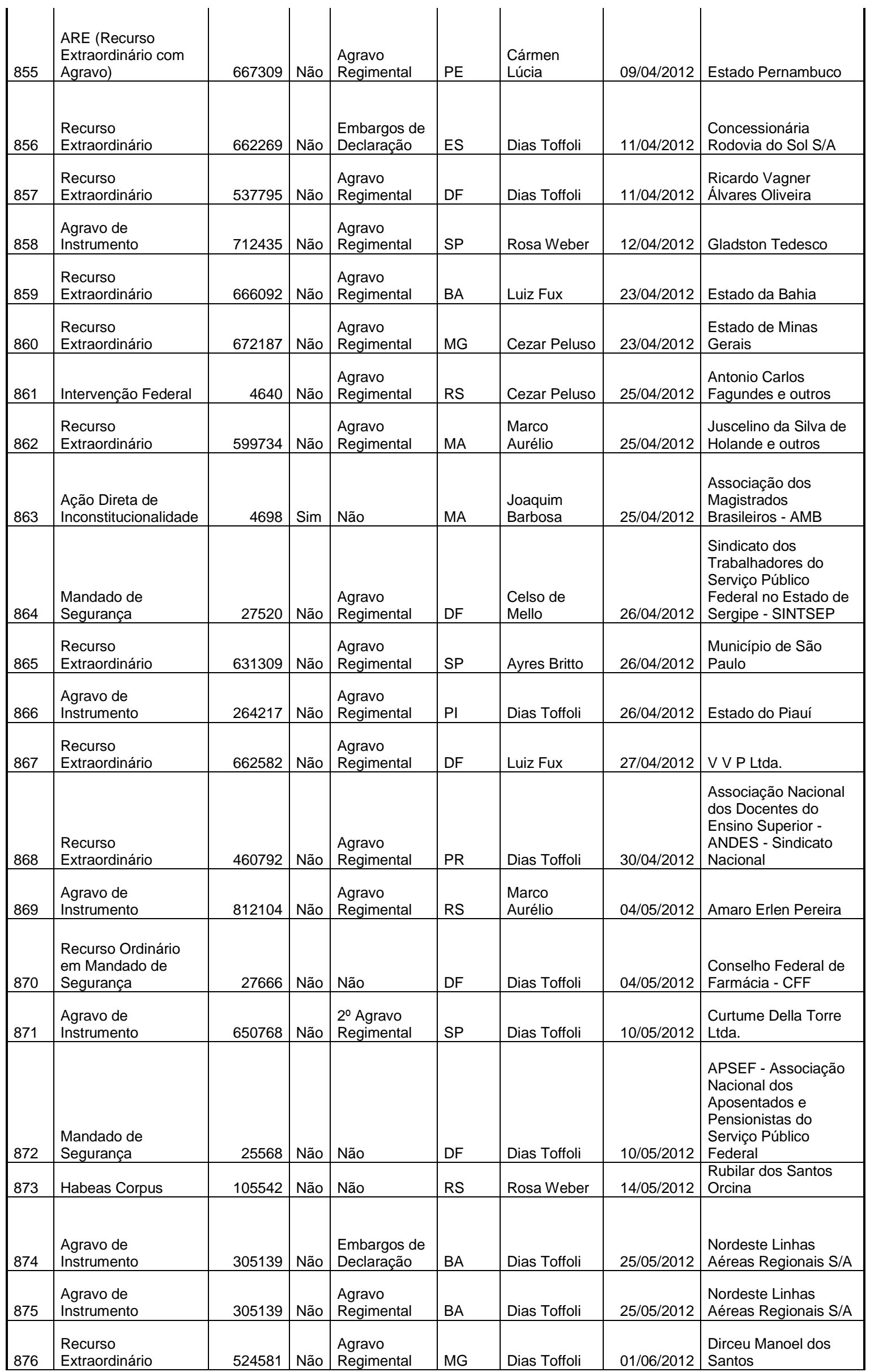




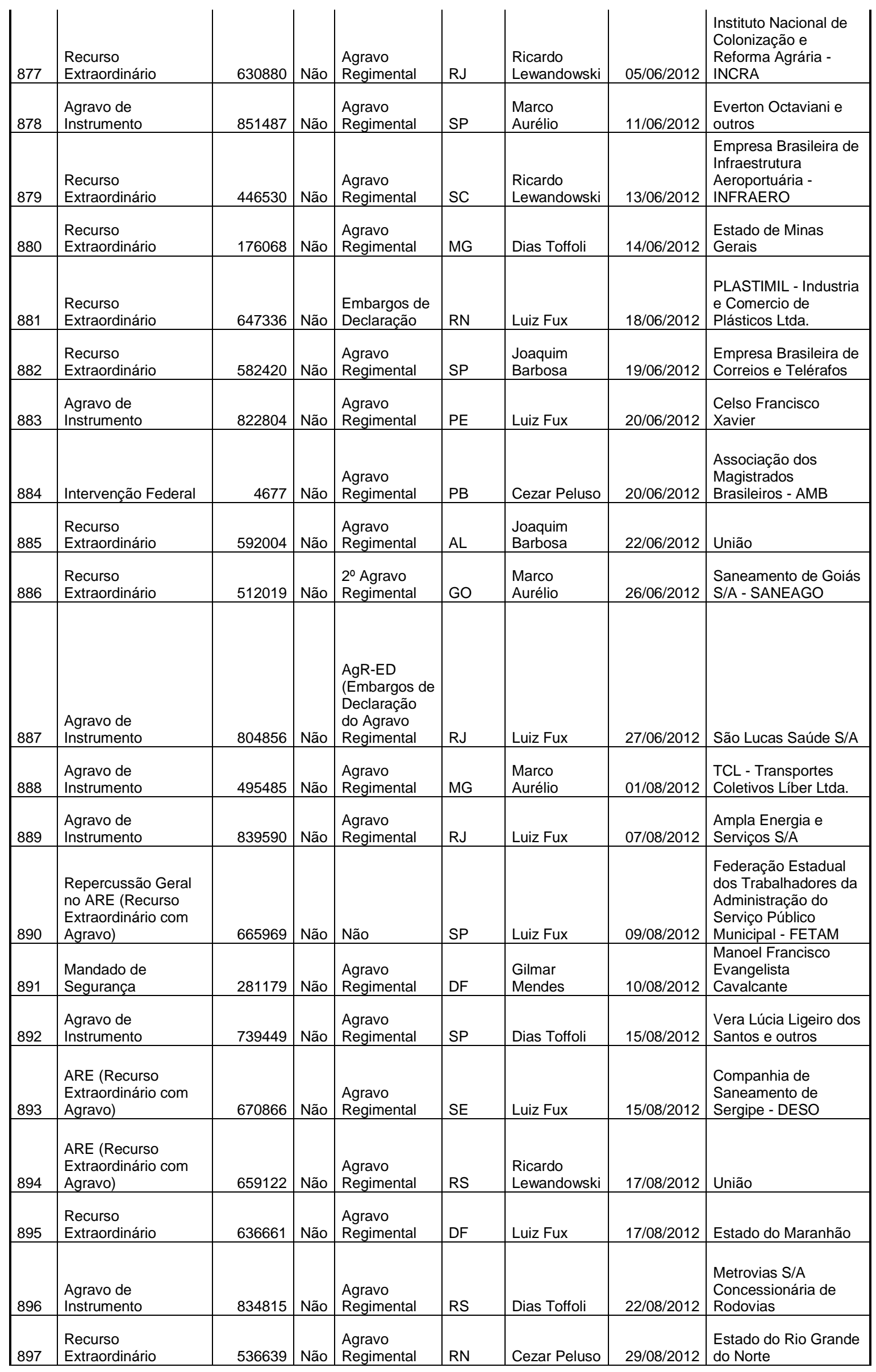




\begin{tabular}{|c|c|c|c|c|c|c|c|c|}
\hline 898 & $\begin{array}{l}\text { ARE (Recurso } \\
\text { Extraordinário com } \\
\text { Agravo) } \\
\end{array}$ & 665977 & Não & $\begin{array}{l}\text { Agravo } \\
\text { Regimental } \\
\end{array}$ & $\mathrm{DF}$ & Luiz Fux & $30 / 08 / 2012$ & $\begin{array}{l}\text { Marcina Graça de } \\
\text { Alcântara Martins }\end{array}$ \\
\hline 899 & $\begin{array}{l}\text { Recurso } \\
\text { Extraordinário }\end{array}$ & 662808 & Não & $\begin{array}{l}\text { Agravo } \\
\text { Regimental }\end{array}$ & MT & $\begin{array}{l}\text { Gilmar } \\
\text { Mendes }\end{array}$ & 05/09/2012 & Brasil Telecom S/A \\
\hline 900 & Intervenção Federal & 5101 & Não & Não & RS & Cezar Peluso & 06/09/2012 & $\begin{array}{l}\text { Regina Nuria Hidalga } \\
\text { Crespo Beheregaray }\end{array}$ \\
\hline 901 & $\begin{array}{l}\text { Recurso } \\
\text { Extraordinário } \\
\end{array}$ & 591986 & Não & $\begin{array}{l}\text { Agravo } \\
\text { Regimental } \\
\end{array}$ & DF & Dias Toffoli & $10 / 09 / 2012$ & Distrito Federal \\
\hline 902 & $\begin{array}{l}\text { Recurso } \\
\text { Extraordinário }\end{array}$ & 633138 & Não & $\begin{array}{l}\text { Agravo } \\
\text { Regimental }\end{array}$ & DF & Luiz Fux & $21 / 09 / 2012$ & Distrito Federal \\
\hline 903 & $\begin{array}{l}\text { ARE (Recurso } \\
\text { Extraordinário com } \\
\text { Agravo) } \\
\end{array}$ & 699423 & Não & \begin{tabular}{|l} 
Agravo \\
Regimental
\end{tabular} & RJ & Dias Toffoli & $27 / 09 / 2012$ & $\begin{array}{l}\text { Ampla Energia e } \\
\text { Serviços S/A }\end{array}$ \\
\hline 904 & $\begin{array}{l}\text { Agravo de } \\
\text { Instrumento }\end{array}$ & 828372 & Não & $\begin{array}{l}\text { Agravo } \\
\text { Regimental } \\
\end{array}$ & PR & $\begin{array}{l}\text { Marco } \\
\text { Aurélio }\end{array}$ & $27 / 09 / 2012$ & União \\
\hline 905 & $\begin{array}{l}\text { Recurso } \\
\text { Extraordinário }\end{array}$ & 635011 & Não & $\begin{array}{l}2^{\circ} \text { Agravo } \\
\text { Regimental }\end{array}$ & RJ & Luiz Fux & 04/10/2012 & União \\
\hline 906 & $\begin{array}{l}\text { ARE (Recurso } \\
\text { Extraordinário com } \\
\text { Agravo) }\end{array}$ & 698357 & Não & $\begin{array}{l}\text { Agravo } \\
\text { Regimental } \\
\end{array}$ & RS & $\begin{array}{l}\text { Cármen } \\
\text { Lúcia }\end{array}$ & 04/10/2012 & Jayr Maccagnan \\
\hline 907 & $\begin{array}{l}\text { Agravo de } \\
\text { Instrumento }\end{array}$ & 836857 & Não & $\begin{array}{l}\text { Agravo } \\
\text { Regimental }\end{array}$ & SP & $\begin{array}{l}\text { Cármen } \\
\text { Lúcia }\end{array}$ & 04/10/2012 & $\begin{array}{l}\text { Elektro Eletricidade e } \\
\text { Serviços S/A }\end{array}$ \\
\hline 908 & $\begin{array}{l}\text { Recurso } \\
\text { Extraordinário }\end{array}$ & 647881 & Não & \begin{tabular}{|l} 
Agravo \\
Regimental
\end{tabular} & RS & $\begin{array}{l}\text { Cármen } \\
\text { Lúcia }\end{array}$ & 05/10/2012 & União \\
\hline 909 & $\begin{array}{l}\text { Agravo de } \\
\text { Instrumento }\end{array}$ & 772813 & Não & $\begin{array}{l}\text { Agravo } \\
\text { Regimental } \\
\end{array}$ & $\mathrm{GO}$ & Luiz Fux & 09/10/2012 & Estado de Goiás \\
\hline 910 & $\begin{array}{l}\text { Mandado de } \\
\text { Segurança }\end{array}$ & 30749 & Não & Não & DF & $\begin{array}{l}\text { Marco } \\
\text { Aurélio }\end{array}$ & 10/10/2012 & José Eli da Silva \\
\hline 911 & $\begin{array}{l}\text { Recurso } \\
\text { Extraordinário } \\
\end{array}$ & 238048 & Não & $\begin{array}{l}\text { Agravo } \\
\text { Regimental } \\
\end{array}$ & $\mathrm{PE}$ & Dias Toffoli & $16 / 10 / 2012$ & $\begin{array}{l}\text { Estado de } \\
\text { Pernambuco }\end{array}$ \\
\hline 912 & $\begin{array}{l}\text { Recurso } \\
\text { Extraordinário }\end{array}$ & 599661 & Não & \begin{tabular}{|l} 
Agravo \\
Regimental \\
\end{tabular} & MG & $\begin{array}{l}\text { Joaquim } \\
\text { Barbosa } \\
\end{array}$ & $26 / 10 / 2012$ & $\begin{array}{l}\text { Luciane Rotella } \\
\text { Fernandes Murta } \\
\end{array}$ \\
\hline 913 & $\begin{array}{l}\text { ARE (Recurso } \\
\text { Extraordinário com } \\
\text { Agravo) }\end{array}$ & 687579 & Não & \begin{tabular}{|l} 
Agravo \\
Regimental \\
\end{tabular} & $\mathrm{BA}$ & Luiz Fux & $09 / 11 / 2012$ & Estado da Bahia \\
\hline 914 & $\begin{array}{l}\text { Recurso } \\
\text { Extraordinário } \\
\end{array}$ & 590964 & Não & \begin{tabular}{|l|} 
Agravo \\
Regimental \\
\end{tabular} & $\mathrm{AL}$ & Dias Toffoli & $12 / 11 / 2012$ & Estado de Alagoas \\
\hline 915 & $\begin{array}{l}\text { Agravo de } \\
\text { Instrumento }\end{array}$ & 642067 & Não & $\begin{array}{l}\text { Embargos de } \\
\text { Declaração } \\
\end{array}$ & RJ & $\begin{array}{l}\text { Celso de } \\
\text { Mello }\end{array}$ & $13 / 11 / 2012$ & $\begin{array}{l}\text { Município do Rio de } \\
\text { Janeiro }\end{array}$ \\
\hline 916 & $\begin{array}{l}\text { Mandado de } \\
\text { Segurança }\end{array}$ & 30323 & Não & Não & $\mathrm{DF}$ & Dias Toffoli & $21 / 11 / 2012$ & $\begin{array}{l}\text { Paulo Roberto Lobo } \\
\text { da Rocha }\end{array}$ \\
\hline 917 & $\begin{array}{l}\text { ARE (Recurso } \\
\text { Extraordinário com } \\
\text { Agravo) }\end{array}$ & 641702 & Não & $\begin{array}{l}\text { Embargos de } \\
\text { Declaração }\end{array}$ & $\mathrm{DF}$ & $\begin{array}{l}\text { Cármen } \\
\text { Lúcia }\end{array}$ & $22 / 11 / 2012$ & União \\
\hline 918 & $\begin{array}{l}\text { ARE (Recurso } \\
\text { Extraordinário com } \\
\text { Agravo) }\end{array}$ & 665977 & Não & $\begin{array}{l}\text { Agr-ED-ED } \\
\text { (Embargos de } \\
\text { Declaração } \\
\text { nos } \\
\text { Embargos de } \\
\text { Declaração } \\
\text { no Agravo } \\
\text { Regimental }\end{array}$ & DF & Luiz Fux & $03 / 12 / 2012$ & $\begin{array}{l}\text { Marcina Graça de } \\
\text { Alcântara Martins }\end{array}$ \\
\hline
\end{tabular}




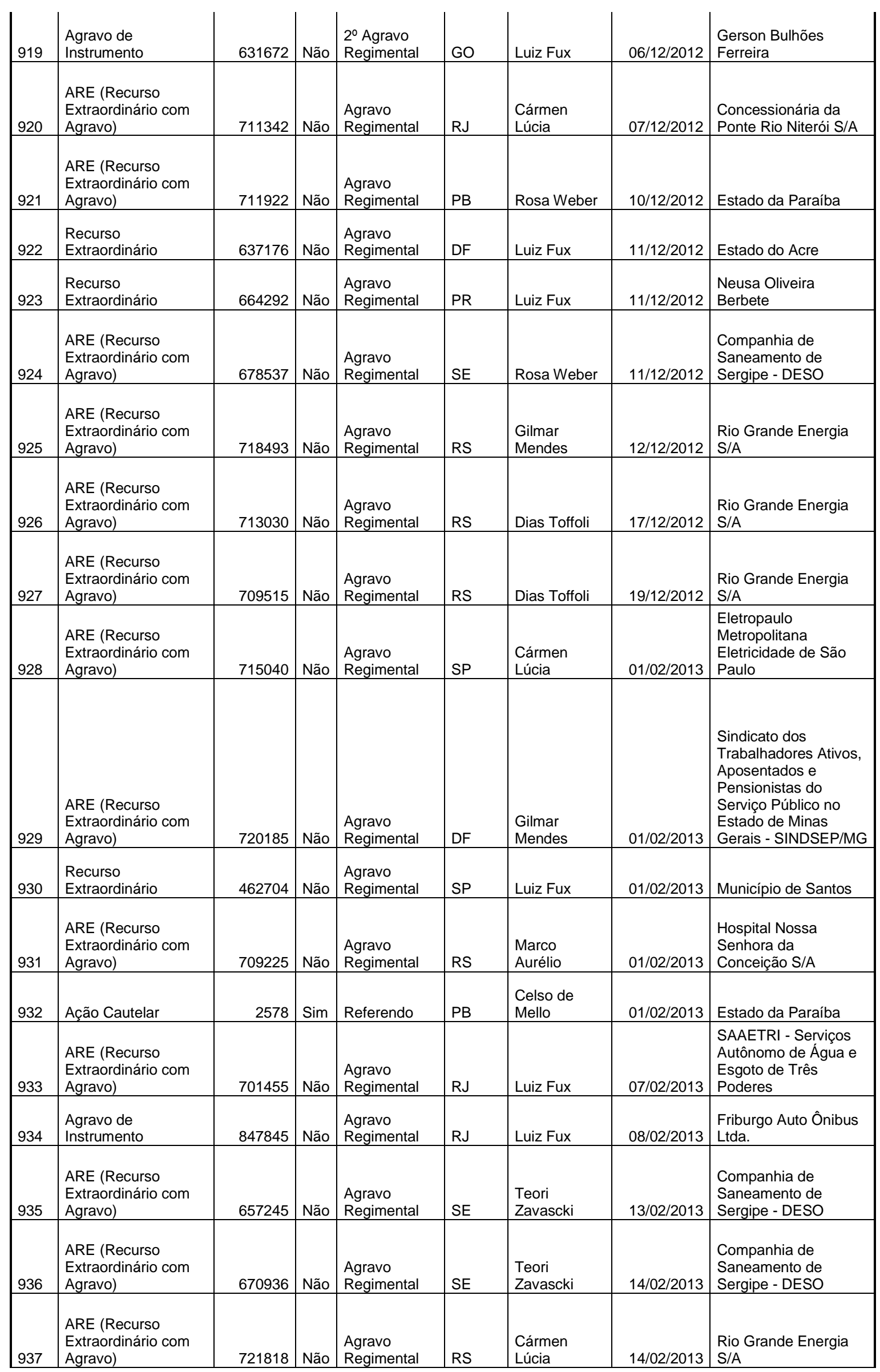




\begin{tabular}{|c|c|c|c|c|c|c|c|c|}
\hline 938 & $\begin{array}{l}\text { ARE (Recurso } \\
\text { Extraordinário com } \\
\text { Agravo) }\end{array}$ & 696263 & Não & $\begin{array}{l}\text { Agravo } \\
\text { Regimental }\end{array}$ & $M G$ & Luiz Fux & 19/02/2013 & $\begin{array}{l}\text { Município de Belo } \\
\text { Horizonte }\end{array}$ \\
\hline 939 & $\begin{array}{l}\text { ARE (Recurso } \\
\text { Extraordinário com } \\
\text { Agravo) }\end{array}$ & 716672 & Não & $\begin{array}{l}\text { Agravo } \\
\text { Regimental }\end{array}$ & RS & Luiz Fux & 19/02/2013 & $\begin{array}{l}\text { Rio Grande Energia } \\
\text { S/A }\end{array}$ \\
\hline 940 & $\begin{array}{l}\text { Mandado de } \\
\text { Segurança }\end{array}$ & 30329 & Não & Não & DF & $\begin{array}{l}\text { Cármen } \\
\text { Lúcia }\end{array}$ & 20/02/2013 & $\begin{array}{l}\text { Stael Cavalcanti } \\
\text { Martins de Araujo }\end{array}$ \\
\hline 941 & $\begin{array}{l}\text { Agravo de } \\
\text { Instrumento }\end{array}$ & 850632 & Não & $\begin{array}{l}\text { Agravo } \\
\text { Regimental }\end{array}$ & RS & Luiz Fux & $21 / 02 / 2013$ & $\begin{array}{l}\text { Faster Boy } \\
\text { Distribuidora Ltda. }\end{array}$ \\
\hline 942 & $\begin{array}{l}\text { Recurso } \\
\text { Extraordinário } \\
\end{array}$ & 642536 & Não & $\begin{array}{l}\text { Agravo } \\
\text { Regimental }\end{array}$ & AP & Luiz Fux & $27 / 02 / 2013$ & Estado do Amapá \\
\hline 943 & $\begin{array}{l}\text { Recurso } \\
\text { Extraordinário }\end{array}$ & 588426 & Não & $\begin{array}{l}\text { Agravo } \\
\text { Regimental }\end{array}$ & RJ & Luiz Fux & 28/02/2013 & $\begin{array}{l}\text { Câmara Municipal do } \\
\text { Estado do Rio de } \\
\text { Janeiro } \\
\end{array}$ \\
\hline 944 & $\begin{array}{l}\text { ARE (Recurso } \\
\text { Extraordinário com } \\
\text { Agravo) }\end{array}$ & 662624 & Não & $\begin{array}{l}\text { AgR-ED } \\
\text { (Embargos de } \\
\text { Declaração } \\
\text { do Agravo } \\
\text { Regimental } \\
\end{array}$ & RJ & Luiz Fux & 28/02/2013 & $\begin{array}{l}\text { Estado do Rio de } \\
\text { Janeiro }\end{array}$ \\
\hline 945 & $\begin{array}{l}\text { Recurso } \\
\text { Extraordinário }\end{array}$ & 596478 & Não & $\begin{array}{l}\text { Agravo } \\
\text { Regimental }\end{array}$ & $\mathrm{RR}$ & Dias Toffoli & $01 / 03 / 2013$ & Estado de Roraima \\
\hline 946 & $\begin{array}{l}\text { Ação Direta de } \\
\text { Inconstitucionalidade }\end{array}$ & 4907 & Sim & Não & DF & $\begin{array}{l}\text { Ricardo } \\
\text { Lewandowski }\end{array}$ & $08 / 03 / 2013$ & $\begin{array}{l}\text { ABRAFIX - } \\
\text { Associação Brasileira } \\
\text { de Concessionárias } \\
\text { de Serviço Telefônico } \\
\text { Fixo Comutado } \\
\end{array}$ \\
\hline 947 & $\begin{array}{l}\text { Recurso } \\
\text { Extraordinário } \\
\end{array}$ & 356677 & Não & Não & MG & $\begin{array}{l}\text { Marco } \\
\text { Aurélio }\end{array}$ & $12 / 03 / 2013$ & $\begin{array}{l}\text { Deine Suarte Carrilho } \\
\text { e otros }\end{array}$ \\
\hline 948 & $\begin{array}{l}\text { Recurso } \\
\text { Extraordinário } \\
\end{array}$ & 702617 & Não & $\begin{array}{l}\text { Agravo } \\
\text { Regimental } \\
\end{array}$ & $\mathrm{AM}$ & Luiz Fux & $21 / 03 / 2013$ & $\begin{array}{l}\text { Procurador-Geral do } \\
\text { Estado do Amazonas }\end{array}$ \\
\hline 949 & $\begin{array}{l}\text { Agravo de } \\
\text { Instrumento }\end{array}$ & 814461 & Não & $\begin{array}{l}\text { Agravo } \\
\text { Regimental }\end{array}$ & $M G$ & Dias Toffoli & 21/03/2013 & $\begin{array}{l}\text { Telemar Norte Leste } \\
\text { S/A }\end{array}$ \\
\hline 950 & $\begin{array}{l}\text { Recurso } \\
\text { Extraordinário }\end{array}$ & 467573 & Não & $\begin{array}{l}2^{\circ} \text { Agravo } \\
\text { Regimental }\end{array}$ & PR & $\begin{array}{l}\text { Celso de } \\
\text { Mello }\end{array}$ & $22 / 03 / 2013$ & Estado do Paraná \\
\hline 951 & $\begin{array}{l}\text { Agravo de } \\
\text { Instrumento }\end{array}$ & 849417 & Não & $\begin{array}{l}\text { Agravo } \\
\text { Regimental } \\
\end{array}$ & $\mathrm{PI}$ & Luiz Fux & 25/03/2013 & José Ribeiro e Silva \\
\hline 952 & $\begin{array}{l}\text { ARE (Recurso } \\
\text { Extraordinário com } \\
\text { Agravo) }\end{array}$ & 719772 & Não & $\begin{array}{l}\text { Agravo } \\
\text { Regimental }\end{array}$ & DF & $\begin{array}{l}\text { Celso de } \\
\text { Mello }\end{array}$ & $26 / 03 / 2013$ & $\begin{array}{l}\text { Viação Valmir Amaral } \\
\text { Ltda. }\end{array}$ \\
\hline 953 & $\begin{array}{l}\text { ARE (Recurso } \\
\text { Extraordinário com } \\
\text { Agravo) }\end{array}$ & 721775 & Não & $\begin{array}{l}\text { Agravo } \\
\text { Regimental }\end{array}$ & RS & Luiz Fux & 01/04/2013 & $\begin{array}{l}\text { Rio Grande Energia } \\
\text { S/A }\end{array}$ \\
\hline 954 & $\begin{array}{l}\text { ARE (Recurso } \\
\text { Extraordinário com } \\
\text { Agravo) }\end{array}$ & 723121 & Não & $\begin{array}{l}\text { Agravo } \\
\text { Regimental }\end{array}$ & RS & Rosa Weber & $01 / 04 / 2013$ & $\begin{array}{l}\text { Rio Grande Energia } \\
\text { S/A }\end{array}$ \\
\hline 955 & $\begin{array}{l}\text { ARE (Recurso } \\
\text { Extraordinário com } \\
\text { Agravo) }\end{array}$ & 681449 & Não & $\begin{array}{l}\text { Agravo } \\
\text { Regimental }\end{array}$ & RS & $\begin{array}{l}\text { Cármen } \\
\text { Lúcia }\end{array}$ & $04 / 04 / 2013$ & $\begin{array}{l}\text { Rio Grande Energia } \\
\text { S/A }\end{array}$ \\
\hline 956 & $\begin{array}{l}\text { ARE (Recurso } \\
\text { Extraordinário com } \\
\text { Agravo) }\end{array}$ & 733904 & Não & $\begin{array}{l}\text { Agravo } \\
\text { Regimental } \\
\end{array}$ & CE & $\begin{array}{l}\text { Teori } \\
\text { Zavascki }\end{array}$ & $18 / 04 / 2013$ & Estado do Ceará \\
\hline 957 & $\begin{array}{l}\text { Recurso } \\
\text { Extraordinário }\end{array}$ & 535085 & Não & $\begin{array}{l}\text { Agravo } \\
\text { Regimental }\end{array}$ & GO & $\begin{array}{l}\text { Gilmar } \\
\text { Mendes }\end{array}$ & $23 / 04 / 2013$ & Estado de Goiás \\
\hline 958 & $\begin{array}{l}\text { Recurso } \\
\text { Extraordinário }\end{array}$ & 717389 & Não & $\begin{array}{l}\text { Agravo } \\
\text { Regimental }\end{array}$ & RS & $\begin{array}{l}\text { Marco } \\
\text { Aurélio } \\
\end{array}$ & $24 / 04 / 2013$ & $\begin{array}{l}\text { Terezinha Boreli } \\
\text { Vittorazzi }\end{array}$ \\
\hline
\end{tabular}




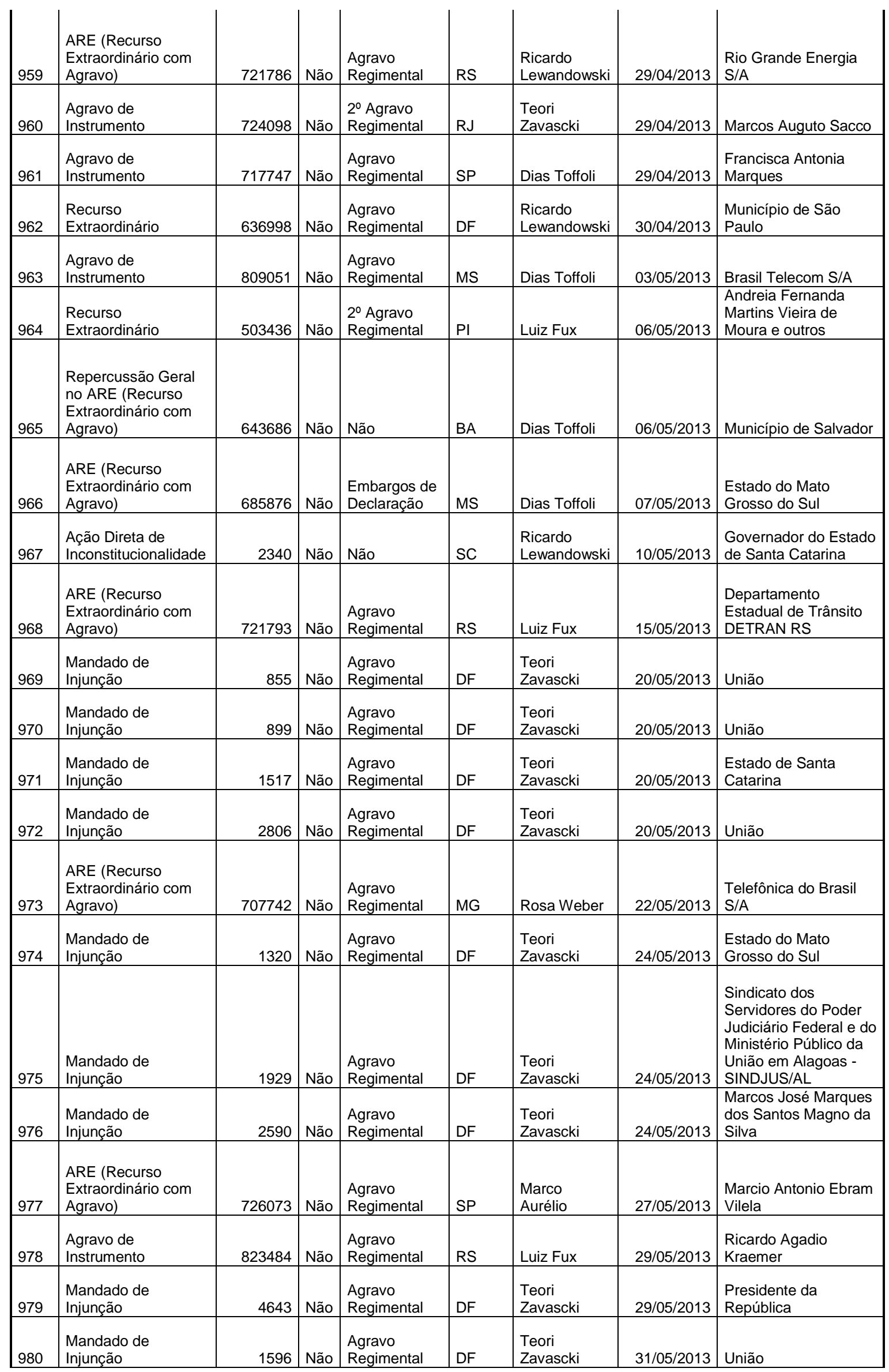




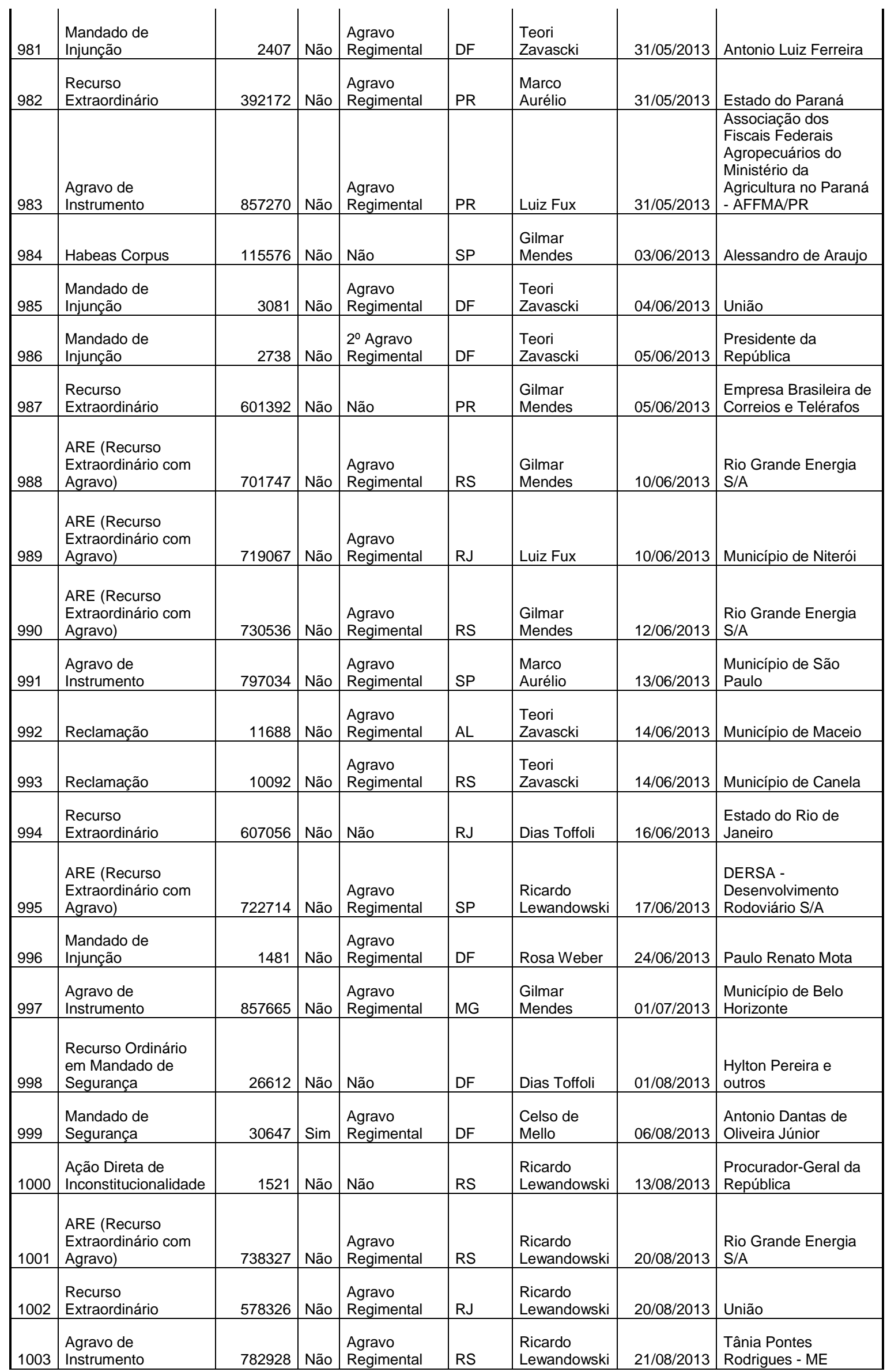




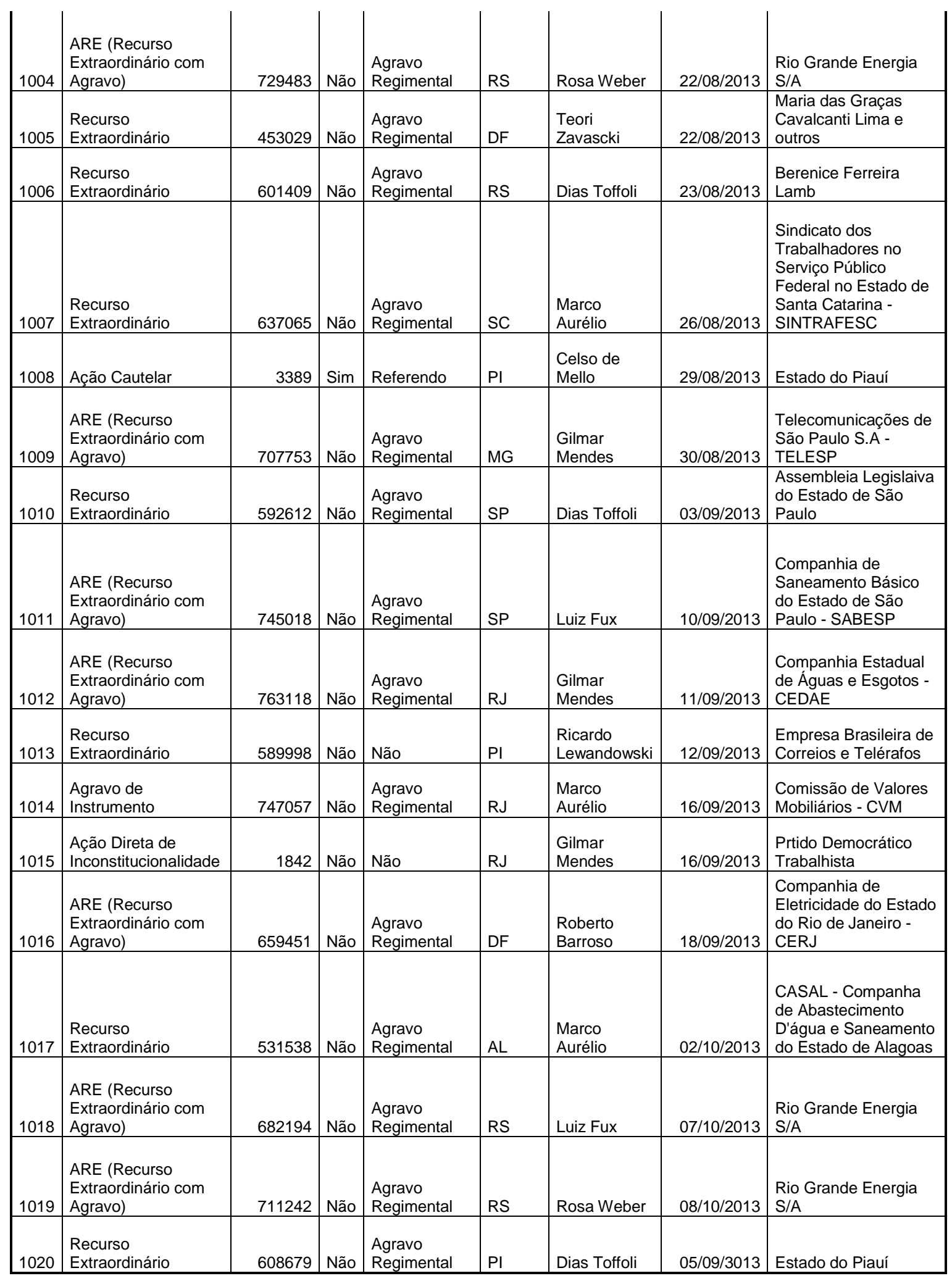




\section{ANEXO II - FORMULÁRIO DE ANÁLISE DE CASOS}

\begin{tabular}{|c|c|}
\hline Número de Controle & \\
\hline Nome do caso & \\
\hline Tema & \\
\hline Medida Judicial & \\
\hline É recurso? & \\
\hline E cautelar? & \\
\hline $\begin{array}{l}\text { Número do } \\
\text { processo }\end{array}$ & \\
\hline Requerente & \\
\hline Requerido & \\
\hline Interessados & \\
\hline Órgão julgador & \\
\hline Min. Relator & \\
\hline $\begin{array}{l}\text { Min. Relator para } \\
\text { Acórdão }\end{array}$ & \\
\hline $\begin{array}{l}\text { Participaram do } \\
\text { julgamento }\end{array}$ & \\
\hline Não compareceram & \\
\hline Resultado & \\
\hline Placar & \\
\hline Divergência & \\
\hline Data de propositura & \\
\hline Data de julgamento & \\
\hline $\begin{array}{l}\text { Data de publicação } \\
\text { de Acórdão }\end{array}$ & \\
\hline Resumo da decisão & \\
\hline Resumo do caso & \\
\hline $\begin{array}{l}\text { Abordagem do } \\
\text { serviço público }\end{array}$ & \\
\hline $\begin{array}{l}\text { Dispositivos } \\
\text { constitucionais } \\
\text { envolvidos }\end{array}$ & \\
\hline $\begin{array}{l}\text { Decisão sobre } \\
\text { serviço público é } \\
\text { central ou marginal? }\end{array}$ & \\
\hline Comentários & \\
\hline
\end{tabular}




\section{ANEXO III - PLANILHA DE CONTROLE}

[documento apresentado em separado] 


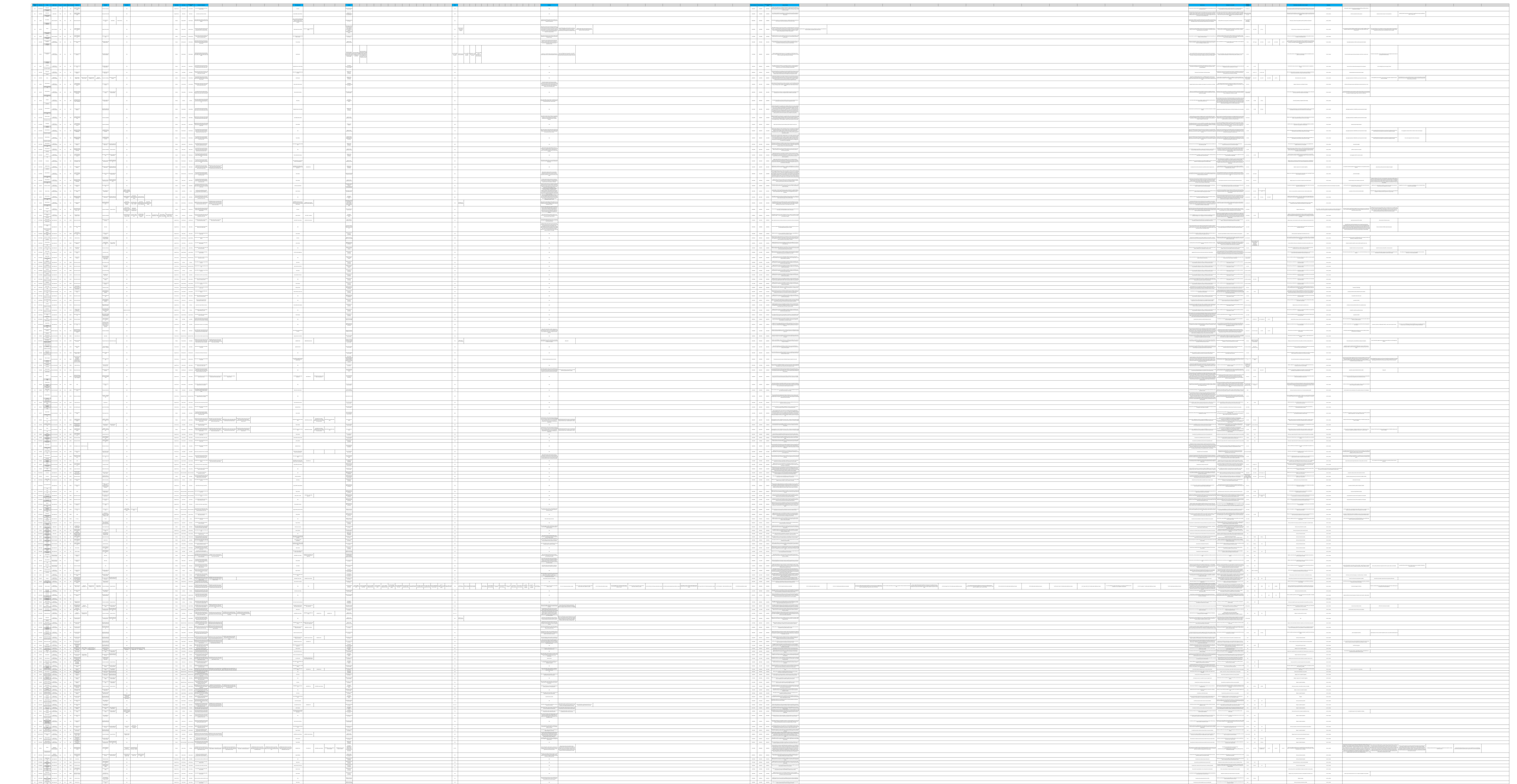



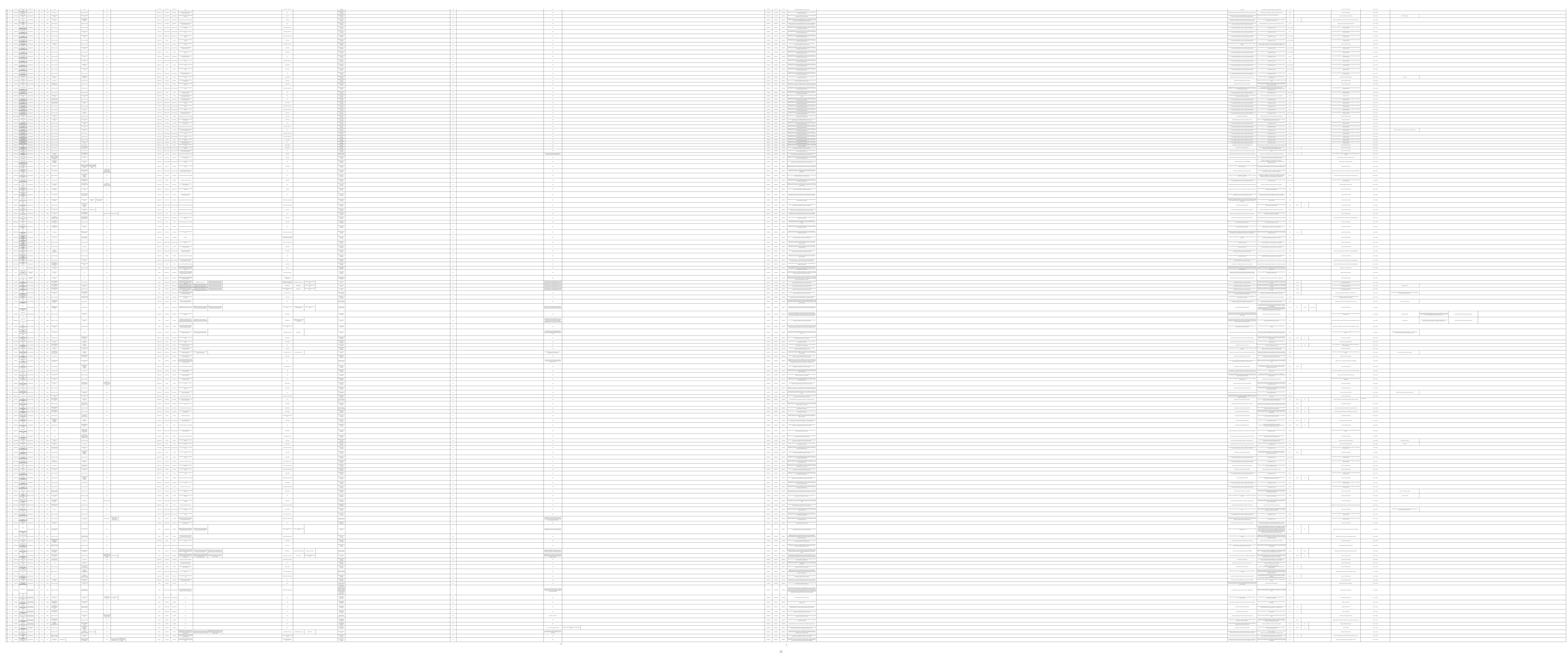